\title{
Diatoms in Lake Sediments as Proxies of Climatic Variation Throughout the Latest Holocene
}

\author{
By
}

\author{
Scott James Hutchinson
}

A thesis submitted to the Faculty of Graduate and Postdoctoral Affairs in partial fulfillment of the requirements for the degree of

Master of Science

In

Earth Sciences

Carleton University

Ottawa, Ontario

(C)2019 Scott James Hutchinson 


\begin{abstract}
This thesis is composed of manuscripts investigating the impact of climate events throughout the past $\sim 2800$ years on conditions within the lacustrine environment of Pocket Lake as reflected in changes of diatom assemblage. The first manuscript presented in chapter 2 is composed of a broad, paleoclimatic reconstruction at a resolution of $\sim 20-30$ years per sample based on changes in diatom assemblage integrated with geochemical and particle size datasets from the same core. In the second chapter a high-resolution investigation into the impact of the deposition of airfall tephra into Pocket Lake is presented. Together, these studies provide insight into the impact of broader decadal scale climate cycles and instantaneous, episodic events allowing for a more comprehensive understanding of their impact on lakes in sensitive, northern locations. These reconstructions will help inform predications regarding the potential impact of $21^{\text {st }}$ century climate change.
\end{abstract}




\section{Acknowledgements}

Firstly, I would like to thank my supervisors Drs. Tim Patterson, Paul Hamilton and Jennifer Galloway. Without their continuous support, encouragement and feedback I would not have been able to complete this project. I'm extremely grateful to them for taking me on and giving me this opportunity.

I would also like to extend my gratitude to the rest of the Patterson Research Group, especially Nawaf Nasser who always made himself available and took the time to provide thoughtful advice and guidance at all stages of this project. Even though he had his own demanding research, he would always set aside time to teach me statistical concepts, help me troubleshoot issues, and talk about any aspects of this project. For that I will be forever grateful. I would also like to single out Vanessa Sinclair. She was always available to talk and to bounce ideas off. Her encouragement and feedback and encouragement was invaluable, especially in the last few months and for that I am extremely grateful.

I would also like to thank team members who collected the cores: Andrew Macumber then of Carleton University, Joel Dragon-Smith of the North Slave Métis Alliance, and Kevin Minus of Golder Associates Ltd.

Financial support for this project was provided through the Research Affiliate Program (RAP) of Natural Resources Canada. Other Financial support was provided through the Northern Scientific Training Program (NSTP).

Lastly, I would like to thank my friends and family for their constant support for me throughout these past few years. 


\section{Table of Contents}

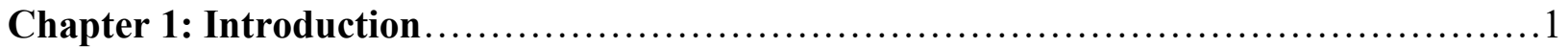

1.1 Research Objectives........................................................

1.2 Climate Change at High Latitudes............................................

1.3 Diatoms in Northern Lakes................................................

1.4 Research Gaps Addressed................................................4

1.5 Structure of Thesis......................................................... 5

Chapter 2: A Diatom Based Paleolimnological Reconstruction of a Small, Subarctic Lake, Northwest Territories, Canada ................................................... 7

2.1 Abstract.....................................................................

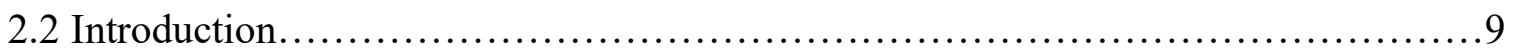

2.3 Study Site ............................................................ 12

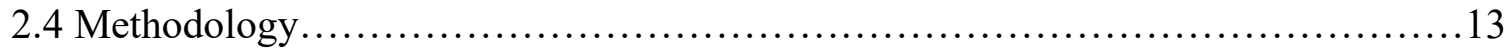

2.5 Results.................................................................. 18

2.5.1 Particle Size Analysis and End-Member Mixing Analysis.................. 18

2.5.2 Diatom Analysis................................................. 20

2.5.3 Bulk Sediment Geochemistry....................................22

2.5.4 Redundancy (RDA) Analysis.....................................24

2.6 Discussion........................................................... 28

2.7 Conclusions.......................................................... 36

Chapter 3: Diatom ecological response to deposition of the 833-850 CE White River Ash (east lobe) ashfall in a small subarctic Canadian lake.................................. 38

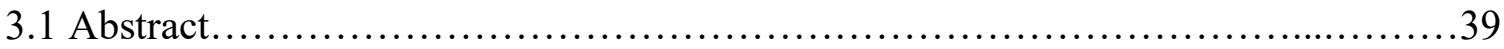

3.2 Introduction................................................................ 41

3.3 The Mount Churchill Eruptions and the White River Ash.........................44

3.3 Study Site ................................................................. 46

3.4 Methodology......................................................... 47

3.5 Results............................................................... 52

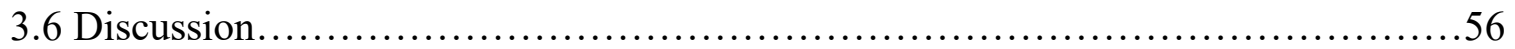

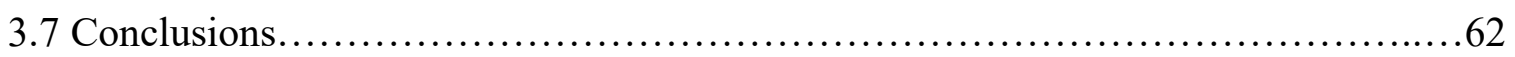

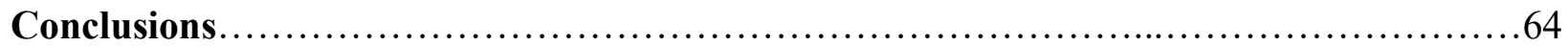

References......................................................................... 71

Appendix A: Appendix A: Comprehensive Diatom Counts for PKT_2FR2 _.............89

Appendix B: Comprehensive Diatom Counts for PKT_2FR1 ...........................119 Appendix C: Selected Geochemical Data, End-Member Proportions, Sedimentation Rate

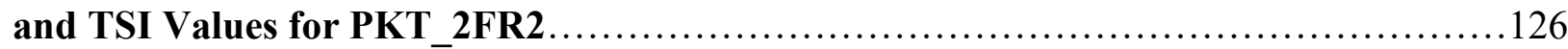




\section{List of Figures}

Figure 2.1 Location of the study site within the Northwest Territories, Canada.................13

Figure 2.2 Non-metric Multidimensional Scaling analysis...............................25

Figure 2.3 RDA tri-plot......................................................... 26

Figure 2.4 Stratigraphic profiles of significant diatom groups and environmental parameters

determined by interactive redundancy analysis (RDA) to be important......................27

Figure 2.5 SEM Images of key taxa documented in the Pocket Lake Core....................28

Figure 3.1 The location of the study site relative to Mount Churchill with the WRAe extent given

by Lerbekmo (2008; dashed line) and by Robinson2001; solid line).....................47

Figure 3.2 Age-depth model produced for PKT 2 FR1 ................................... 51

Figure 3.3 Non-metric Multidimensional Scaling analysis..............................55

Figure 3.4: Relative abundance profiles of diatom taxa from Pocket Lake...........,,,,,,.....56 


\section{List of Tables}

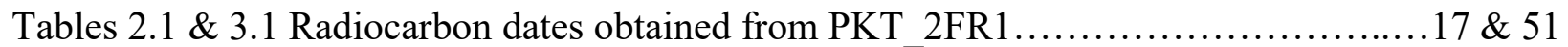




\section{List of Appendices}

Appendix A: Appendix A: Comprehensive Diatom Counts for PKT 2 FR2 $\ldots \ldots \ldots \ldots \ldots \ldots . . . . .65$

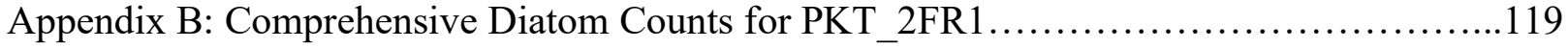

Appendix C: Selected Geochemical Data, End-Member Proportions, Sedimentation Rate and TSI

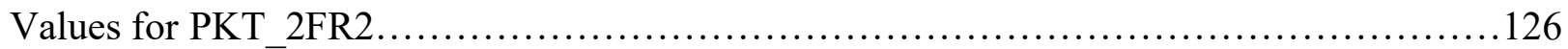




\section{Chapter 1: Introduction}

\subsection{Research objectives}

The primary objective of this thesis was to develop a paleoclimatic reconstruction based on changes in water quality in Pocket Lake, a small subarctic lake the Northwest Territories, Canada, over the recent Holocene. Changes in diatom assemblages over the past $\sim 2800$ years were assessed in a freeze core obtained from the lake. The resulting dataset was integrated with existing geochemical and grain size datasets to relate changes in diatom assemblage to other environmental parameters. Conditions within a given lake are controlled by their geographical context, catchment dynamics and regional climate so by reconstruction conditions within Pocket Lake, it is possible infer broader environmental processes (Pienitz et al., 1995; Batterbee, 2000; Juggins and Birks, 2002). In order to make accurate predictions regarding the impact of future climate change, information from past events is required. Modern environmental monitoring has not existed long enough to fill this role; therefore, data must be obtained from available proxy sources (Weckstrom et al., 1997; Lim et al., 2008). The development of a paleoclimatic reconstruction based on the proxy record in the lake sediments of Pocket Lake will provide insight into the impact of historical climate events. This will allow for a better understanding of how warming in the $21^{\text {st }}$ century may impact the region (Pienitz et al., 1995; Lim et al., 2001).

A secondary objective of this project was investigating diatom response to airfall tephra. A layer of tephra associated with the White River Ash Eastern Lobe was observed in Pocket Lake. The White River Ash was generated by the eruption of Mt. Churchill in Alaska around 833-850 AD (Patterson et al., 2017). The material in Pocket Lake represents the eastern most macroscopic 
observation of the White River Ash and is the only documentation of it in the central Northwest Territories (Patterson et al., 2017). This provides a unique opportunity to assess the impact of the White River Ash on lacustrine environments in the region as represented by changes in diatom assemblages present in the core sections above and below the layer. Through this, it will be possible to develop a more comprehensive understanding of the ecological response and recovery of sensitive northern lakes to these events.

\subsection{Climate Change at High Latitudes}

Climate change in the $21^{\text {st }}$ century is expected to impact high-latitude locations to a larger degree than those at lower latitudes (Lim et al., 2008). Even minor changes in climatic conditions can significantly impact the regional environment (Weckstom et al., 2007). For example, habitat loss stemming from climate change may significantly affect regional ecology with implications for the people in the area who depend on those resources (Lim et al., 2008; ACAI, 2004). Additionally, previous research has found that climate change can significantly impact contaminant fate and transport within the region (Spence et al., 2015). The mobility of many metal and metalloid contaminants makes a straight chemostratigraphic profile ineffective at analyzing temporal variation in their concentration. Evaluating the relationship between diatom assemblage and geochemical variation will help develop a clearer understanding of historical geochemical variability. This will be used to better understand the driving forces behind natural variability of metal and metalloid contaminant variation as it relates to long term climatic cycles, 
trends and major climatic events allowing for better predictions regarding the impact of $21^{\text {st }}$ climate change.

\subsection{Diatoms in Northern Lakes}

Diatoms are a major forms of algae and respresenting single-celled organisms with shells made of silica (Dixit et al., 1992). In the central Northwest Territories, and other high-latitude locations, diatoms in lake sediments are particularly well suited for developing paleoclimatic reconstructions. Diatoms can withstand extreme environments and are ubiquitous in the lakes of northern Canada (Batterbee, 2000; Joynt III et al., 2001; Pienitz et al., 1995). Additionally, diatoms are extremely diverse with certain taxa existing within a narrow optimum. Therefore, small changes within a system will elicit a large response from the community. The silica composition of diatom valves allows them to be well preserved in lake sediments thereby providing a continuous record of environmental change (Batterbee 2000; Lotter et al., 1998). Diatoms are extremely sensitive to changes in water quality and thus through assessing changes in assemblage structure throughout time, we can infer changes past in water quality (Dixit et al., 1992). This information may then be integrated with other datasets and previously established paleoclimatic data allowing for a better understanding of how climate change can impact the lacustrine environment.

Research conducted prior to this study has linked selected diatom taxa observed in the sediments of Pocket Lake to specific conditions. For example, Staurosira venter is one of the primary species at the basal portion of the core. Other studies have found this species to be 
strongly associated with alkaline conditions (Karst-Riddoch et al., 2005; Pienitz et al., 1999).

Furthermore, it has been found to colonize rapidly allowing it to outcompete other less resilient species and thrive in lakes where conditions are rapidly changing (Le Blanc et al., 2004). The dominance of $S$. venter may be indicative of these conditions within Pocket Lake. The susequent rapid decline and disappearance of this species may also suggest a shift away from these conditions. Another major species complex observed in Pocket Lake is the Cyclotella sensu lato group. Small, centric taxa such as these tend to be more common in warmer waters as long periods of seasonal ice-cover inhibit the development of a significant planktic population (Saros and Anderson, 2004). Analysing trends in the relative abundance of these species can be used to infer annual temperature changes in the region.

\subsection{Research Gaps Addressed}

Future climate change has the potential to radically impact the regional environment. Accurately predicting the impact of future climate change requires an understanding of past events (Batterbee 2000). The reconstruction resulting from this study will help address this gap. Additionally, this study is notable in that a two-faced freeze corer and custom sledge microtome were used for the collection and processing of the material. Freeze coring mitigates the risk of smearing and homogenization of the material thereby increasing the precision of the proxy data obtained (Galloway et al., 2010). It also allows for the use of a custom sledge microtome for high resolution subsampling (Macumber et al., 2011). The resolution used for this research is much higher than other similar studies (MacDonald et al., 1993; Ruhland and Smol, 2005; Bourgeois et 
al., 2000; Wolfe et al., 1996). Each sample at centimeter interval represents between $\sim 20-30$ years thereby allowing decadal scale processes to be assessed. Synthesis of diatom analysis with particle size and geochemistry also provides insight into the relationship between assemblage and water quality parameters (e.g. $\mathrm{pH}$, turbidity, temperature). This will increase the utility of diatom analysis in other studies.

The observation of a layer of tephra in the core also provides a unique opportunity to study the impact of airfall tephra on a small subarctic lake. This material represents the easternmost macroscopic observation of the White River Ash Eastern Lobe and the only occurrence of visible tephra in a lake located in the central Northwest Territories (Patterson et al., 2017). Sample collection using a freeze corer in conjunction with processing via a custom sledge microtome allowed for a sample resolution of $\sim 1.5$ years. Most prior studies investigating the diatom response to tephra involve tephra much thicker sections than that observed in Pocket Lake and at a far coarser resolution (Harper et al., 1986; Lotter and Birks, 1993; Lotter et al., 1994; Hickman and Reasoner, 1994; Jovanovska et al., 2016). Deposition of airfall tephra often occurs as a nearly instantaneous event. Consequently, the influence of this material is likely to be short lived and may be unobserved at a coarser resolution (Lotter and Birks, 1993). The resolution applied here will help develop a better understanding between the diatoms and conditions within the lacustrine environment thereby increasing the accuracy of future diatom studies. 


\subsection{Structure of Thesis}

The thesis is divided into two chapters each following the manuscript format of a specific

journal. The first (Chapter 2) contains a broad paleoclimatic reconstruction of the past $\sim 2800$ years of the late Holocene. The chapter is formatted for future submission to the journal, Global and Planetary Change. Prior to submission, the manuscript will be edited based on the feedback provided by the co-authors and committee members. The second chapter follows the manuscript format of articles published in PeerJ. This chapter was published in PeerJ in January 2019. It contains a high-resolution diatom analysis of material one $\mathrm{cm}$ above and below a threemillimeter layer of tephra associated with the White River Ash Eastern Lobe. References for each manuscript will be listed at the end of each chapter. 


\section{Chapter 2: A Diatom Based Paleolimnological Reconstruction of a Small, Subarctic Lake, Northwest Territories, Canada}

Scott J. Hutchinson ${ }^{1}$, Paul B. Hamilton ${ }^{2}$, R. Timothy Patterson ${ }^{1}$, Jennifer M. Galloway ${ }^{3}$, Nawaf A. Nasser $^{1}$, Christopher Spence ${ }^{4}$, Hendrik Falck $^{5}$

${ }^{1}$ Ottawa-Carleton Geoscience Center and Department of Earth Sciences, Carleton University, Ottawa, Ontario, K1S5B6 Canada

${ }^{2}$ Research Division, Canadian Museum of Nature, Ottawa, ON, K1P 6P4, Canada

${ }^{3}$ Aarhus Institute of Advanced Studies, Aarhus, Denmark

${ }^{4}$ Environment and Climate Change Canada, 11 Innovation Boulevard, Saskatoon, SK, S7N 3H5, Canada

${ }^{5}$ Northwest Territories Geological Survey, P.O. 4601-B 52 Avenue Yellowknife, NT X1A 2L9, Canada

\subsection{Abstract}

Diatom assemblages deposited over the past $\sim 2800$ years were analyzed in a freeze-core obtained from Pocket Lake, a small, subarctic lake, in the central Northwest Territories, Canada. Changes in diatom assemblages were integrated with elemental and particle size data from the same core to reconstruct past conditions within the lake. Non-metric multidimensional Scaling and Stratigraphically Constrained Incremental Sum of Squares cluster analysis (CONISS) were used 
to delineate five diatom assemblage zones throughout the $118-\mathrm{cm}$ of core studied: Assemblage 1 (131-103 cm; ca. 2860-2260 cal yr BP ); Assemblage 2 (103-64 cm; ca. 2240-1300 cal yr BP); Assemblage 3 (63-54 cm; ca. 1280-1090 cal yr BP); Assemblage 4 (53-40 cm; ca. 1070-815 cal yr BP); and Assemblage 5 (39-13 cm; ca. 795-190 cal yr BP). Redundancy analysis (RDA) was used to assess associations between the five assemblages and environmental parameters (particle size, bulk sediment geochemistry, and a previously published total solar irradiance reconstruction). Assemblage 1 was dominated by alkaliphile taxa most notably, Staurosira venter. In addition, the taxa of Assemblage 1 were often opportunistic species associated with cold waters. This assemblage showed a strong relationship with calcium concentration as an indicator of alkalinity. Both the relationship with calcium and abundance of alkaliphile taxa were strongest in the oldest samples, especially those older than $\sim 2500 \mathrm{cal}$ yr BP. These factors suggest that more alkaline waters prevailed in Pocket Lake between ca. 2860 and ca. 2260 cal yr BP that the succeeding interval. Results from NMDS showed overlap between the uppermost samples of Assemblage 1 and the lowermost of Assemblage 2, indicating a gradual transition between the two. Assemblage 2 showed no apparent association with calcium concentration and was comparatively depleted in alkaliphile and stress indicator taxa. Species tolerant of turbid conditions such as Nitzschia palea were high in relative abundance and taxa favouring warmer waters such as Sellaphora spp. became more prevalent in this Assemblage. A weak relationship with total solar irradiance (TSI) was observed. These data suggest that slightly warmer climate and increased runoff from the catchment developed at this time. These inferences were also supported by an increase in the calculated sedimentation rate. The abundance of Sellaphora spp. and other species associated with warm waters decreases in Assemblage 3, deposited between ca. 1280 and ca. 1090 cal. Yr BP. Sedimentation rate also decreased at this time, suggesting that colder climate with longer periods 
of annual ice cover developed. An increase in diatom species associated with slightly more acidic, biologically productive waters, such as Brachysira microcephala was apparent in Assemblage 4. Warm water taxa such as Sellaphora spp. also characterized Assemblage 4. This time was contemporaneous with the Medieval Climate Anomaly that was a widespread event in the northern hemisphere between ca. 1000 and 700 cal yr BP. A relationship between Assemblages 3, Assemblage 4, and Fe/Mn was also observed that may reflect a change in redox conditions. An increase in sedimentation rate and abundance of warm water diatom taxa suggested that a warming climate had developed at this time. Assemblage 5 occured in the most recent sediments, appearing after ca. 795 cal yr BP. Acidophile species such as Bracysira microcephala and Neidium spp. were high in relative abundance in Assemblage 5. There was also a substantial increase in planktic Cylotella sensu lato, particularly Discotella stelligera. Although an increase in planktic varieties is often associated with warmer conditions, the timing of the dominance of Cyclotella spp. sensu lato coincides with the Little Ice Age (ca. 500-250 cal yr BP). This phenomenon is common to several other Arctic and subarctic lakes, suggesting that the enrichment of Cyclotella sensu lato spp. was driven by factors other than temperature. Although the underlying driver for this is not clear, the pattern emphasizes the sensitivity of high-latitude lakes and the complexity of their response to climate. Overall, the proxy record provided in Pocket Lake shows a large degree of variation throughout the last $\sim 2800$ years. This research provides potential insight into the impact of $21^{\text {st }}$ century climate change on subarctic lake systems.

\subsection{Introduction}

Arctic and subarctic regions are predicted to warm in the $21^{\text {st }}$ century (Callaghan et al. 2013; Delworth et al., 2016; Overpeck et al., 1997). These highly sensitive locations are 
expected to be impacted more quickly and to a larger degree than lower-latitude regions a result of various positive feedbacks (Lim et al., 2001; ACAI, 2004; Manabe et al., 1992; Mitchell et al., 1995; Zwiers et al., 2002). Annual temperatures have risen by $1.5-2^{\circ} \mathrm{C}$ documented since 1980 , with the trend expected to continue in the coming decade (ACIA, 2004). The impact of warming over the $21^{\text {st }}$ century has both societal and environmental implications, for example, changing climatic conditions may lead to habitat loss impacting regional ecology and people depending on these natural resources (Lim et al, 2001; ACIA, 2004). Recent studies have also found that climate change influences regional hydrology and as a result, contaminant transport and fate. A recent study presented in Spence et al. (2015) found that changing streamflow conditions can influence element loading. High-latitude regions with zones of mineralization and legacy contamination from past natural resource development could be dramatically impacted by a shift to more unpredictable climate and warmer temperatures. Climate change has the potential to release geogenic contaminates and remobilize anthropogenic contaminants from legacy contamination sites (MacDonald et al., 2005). The severity of the potential consequences makes accurately predicting the effects of $21^{\text {st }}$ century climate change on aquatic ecosystems increasingly important. By assessing the environmental response to historical climate variability, improved predictions on how sensitive regions may respond to future events may be achieved.

Previous studies have found evidence of late Holocene climatic variation recorded in the sediments of northern lakes (e.g. Pienitz et al., 1999; Le Blanc et al., 2004; Wolfe et al., 1996; Bourgeois et al., 2000; Gajewski et al., 1995; 1997; Dalton et al., 2018; Joynt III et al., 2001; Ruhland and Smol, 2005; Upiter et al., 2014; Overpeck et al., 1997). Conditions within the lacustrine environment are determined by geographical setting, regional climate, and conditions of the catchment (Battarbee, 2000; Lotter et al., 1998; Juggins and Birks, 2002; Pienitz et al., 
1995). Lake biota is extremely responsive to changes in water quality (Dixit et al., 1992; Batterbee et al., 2000). As such, continuous archives of past conditions can be archived in lacustrine sediments (Battarbee, 2000) and can be used to reconstruct changing conditions throughout the life of the lake and ultimately, provide insight into broader regional environmental processes and their ecological impact.

Diatoms preserved in lake sediments are particularly useful as paleolimnological and paleoclimate proxies in high-latitude locations due to their sensitivity, taxonomic resolution, easy preservation and widespread distribution, even in extreme environments (Dixit et al., 1992; Battarbee, 2000). Previous studies have shown a clear link between the diatom species present and specific conditions such as contaminant concentrations, $\mathrm{pH}$, alkalinity, and biological productivity (e.g. Fallu et al., 2000; Hamilton et al., 2015; Dixit et al., 1992; Dixit et al., 2007).

The purpose of this study was to assess changes in diatom assemblage over the past $\sim 2800$ years as recorded in the sediments of Pocket Lake, a small, subarctic lake in the central Northwest Territories, Canada. Pocket Lake was the subject of a previous diatom study presented in Thienpont et al. (2016). The purpose of that study was to investigate the mining impact on the lake and used more recent material whereas this study investigates much older sediments. Diatom assemblages are compared with geochemical and particle size data from the same core, and total solar irradiance (TSI; Steinhilber et al., 2009) to assess the relationship between diatom assemblage and these parameters. Through the synthesis of these datasets historical changes in the water quality of Pocket Lake are reconstructed. By comparing these records with the known timing of various climate events throughout the recent Holocene, we can develop of a more comprehensive understanding of how northern lake environments have responded to climatic 
variation. By understanding the impact of past climatic variation, more precise predictions of the consequences of future climate change can be made.

\subsection{Study Site}

Pocket Lake $(114.3719 \mathrm{~W}, 62.5090 \mathrm{~N})$ is a subarctic lake located on the Giant Mine site roughly $4 \mathrm{~km}$ north of Yellowknife, Northwest Territories Canada (Fig 2.1). It was chosen due to its proximity to the Giant Mine site. However, because the record presented here ceases after $\sim 190$ cal yr BP $(13 \mathrm{~cm})$, the anthropogenic impact of mining was not investigated. Pocket Lake is a small headwater lake located within the southern portion of the Baker Creek watershed. The catchment of Pocket Lake is less than 5 ha comprising an outcrop of bedrock that drains south via a soil filled valley into the lake (Spence et al., 2006).

Pocket Lake is located within the Slave Geologic Province. The bedrock underlying the catchment is made up of the Yellowknife Supergroup that is composed of meta-sedimentary and felsic to mafic meta-volcanic rocks (Boyle, 1960). The meta-sedimentary rocks within the study area consist of greywacke, slate, schist, and phyllite. The arsenic concentrations found in these ranges from 10 ppm to 30 ppm (Boyle, 1960; Yamashita et al., 1999; Kerr, 2006). The volcanic units of this group are primarily basalt, andesite, and pillowed flows trending north-south through the center of the study area (Boyle, 1960). The arsenic concentration documented in these units ranges between 1 and 33 ppm (Cousens, 2000; Cousens et al., 2002; Kerr, 2006). Isolated granitoid intrusions can be found throughout the Yellowknife Supergroup and make up most of the bedrock west of the city of Yellowknife (Boyle, 1960). Although, arsenic concentrations in these intrusions are around $2 \mathrm{ppm}$ (Boyle, 1960) mineralized zones located near the Yellowknife Greenstone Belt have been documented with concentrations up to $90 \mathrm{ppm}$ 
(Kerr, 2006). Except for the mineralized zones, the arsenic concentrations documented in these units are comparable to values observed in basic igneous rocks around the globe (Smedley and Kinninburgh, 2002). However, some tills in the Yellowknife region can contain much higher arsenic concentrations. Arsenic values in in situ weathered rocks over mineralized zones have been reported to be range up to $1560 \mathrm{ppm}$ (Kerr, 2006).

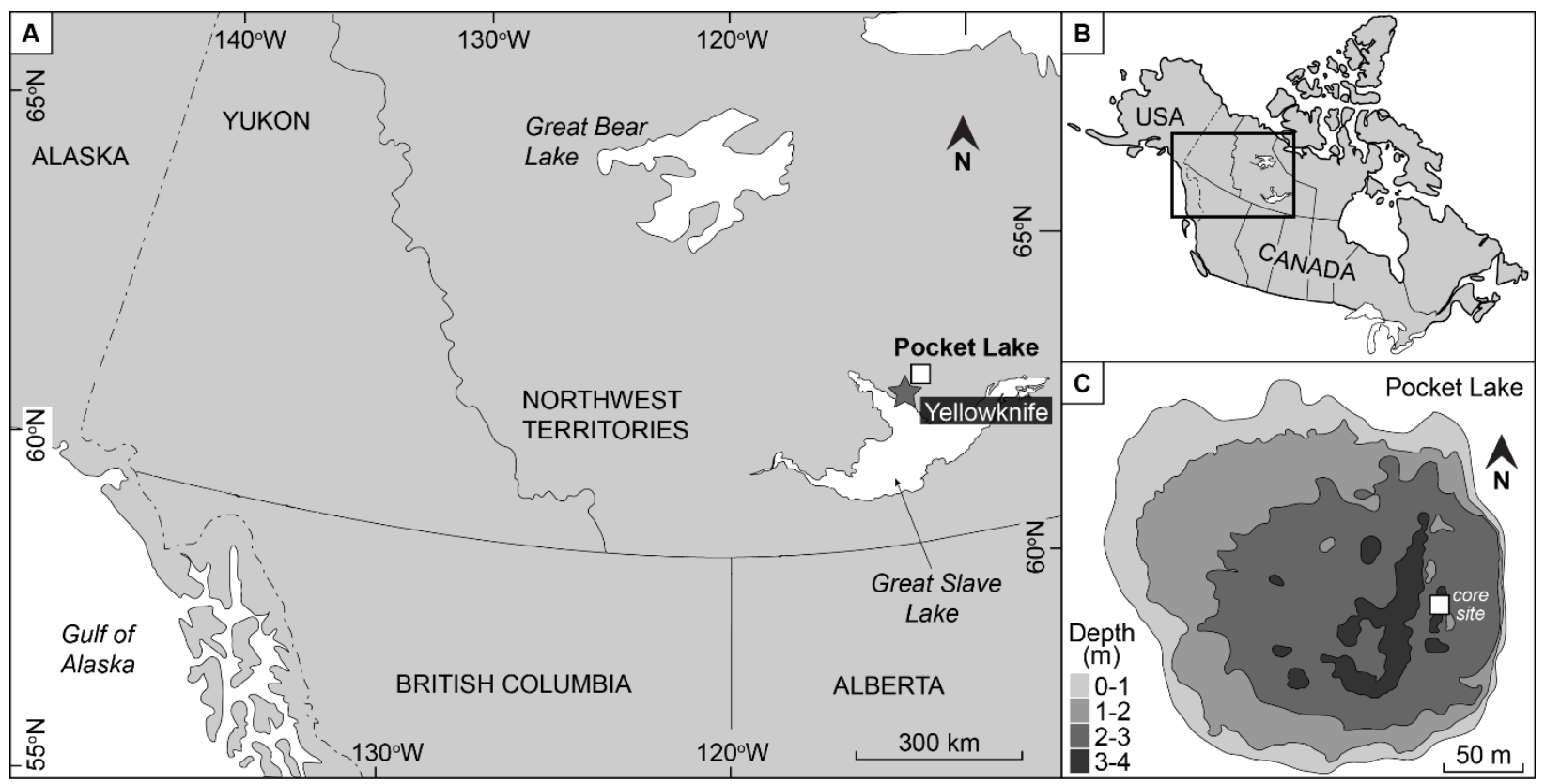

Figure 2.1. Location of the study site within the Northwest Territories, Canada. Modified from Patterson et al. (2017).

\subsection{Methodology}

Two cores, PKT_2FR and PKT_1FR, were collected approximately $3 \mathrm{~m}$ apart from Pocket Lake in 2012 using a two-faced freeze coring device. They were collected from at depth of $\sim 3.5 \mathrm{~m}$ near the $\mathrm{z}_{\max }$ of the lake. Freeze-coring helps mitigate the risk of homogenization of the material and allows for extremely high-resolution sub-sampling (Galloway et al., 2010). PKT_2FR provided roughly $131 \mathrm{~cm}$ of material and PKT_1FR provided $180 \mathrm{~cm}$ of material. PKT_1FR did 
not capture the sediment-water interface material due to over penetration during core collection. As a result, the primary material used in this study was obtained from one face of the first core, PKT_2FR2. One-mm thick sub-samples at 1-cm intervals were obtained from the core using a custom sledge microtome between the depths of 13-131 cm (Macumber et al., 2011). Material from the first $8 \mathrm{~cm}$ was combined into a single sub-sample due to a lack of sediment. Although geochemical analysis was conducted on this sample, there was not enough material remaining for microscopic study. This was also the case for sub-samples between 9-12 cm. Thus, sub-samples at 1-cm intervals from $13-131 \mathrm{~cm}$ depth were used for geochemical and diatom analyses ( $n=118)$. The remaining 1-mm sub-samples were used for particle size analysis $(n=913)$.

Sediment sub-samples were prepared for diatom analysis following a modified version of the protocol outlined in Gajewski et al. (1997). Briefly, 10 milligrams aliquots were placed in centrifuge tubes and freeze dried. Sub-samples were then placed in individual beakers and $10 \mathrm{ml}$ of 1:1 concentrated sulfuric $\left(\mathrm{H}_{2} \mathrm{SO}_{4}\right)$ and nitric $\left(\mathrm{HNO}_{3}\right)$ acid solution were added and heated to digest any organic material present. Resulting residues were then diluted to neutrality and $0.8 \mathrm{ml}$ was placed using a volumetric pipette onto a clear coverglass and left to dry for 24 hours. The coverglass were then mounted to glass slides using Naphrax ${ }^{\circledR}$, a permanent adhesive with a high refractive index 1.65 .

Age-depth relationships were developed using material obtained from the other face of the core (PKT_2FR1). The model was based on radiocarbon dates obtained from 8 horizons and a tephra layer identified as the White River Ash Eastern Lobe, which has a known deposition date of $1150 \mathrm{cal}$ BP (55-56 cm; Patterson et al., 2017) (Table 1). Radiocarbon dates were obtained via the accelerator mass spectrometer at the 14CHRONO Dating Laboratory in Belfast, Northern Ireland, and calibrated with OxCal v4.2 (Bronk Ramsey, 2009) using the IntCal13 
calibration curve (Reimer et al., 2013). Bacon 2.2 (Blaauw and Chisten, 2011; 2013) was then used to develop the final age-depth model for the core using accumulation rate and memory parameter values for lakes within the central Northwest Territories (Crann et al., 2015). The sedimentation rate was calculated by diving each $1-\mathrm{cm}$ interval by the approximate time interval indicated by the age-depth model.

Concentrations of major and trace elements were obtained via inductively coupled plasma-mass spectrometry (ICP-MS) at Acme Laboratories, Vancouver (now Bureau Veritas). The samples were digested using aqua regia $\left(\mathrm{HNO}_{3}\right.$ : $\left.\mathrm{HCL}, 1: 3\right)$. Rock Eval pyrolysis was conducted in order to analyze the organic constituents of the cores. Rock Eval Pyrolysis was only conducted on PKT_1FR1 due to insufficient material provided in the samples from PKT_2FR1. Small sample size compromised the S1, S3, Residual Carbon, and TOC datasets and as a result, only S2 data was used. However, even the accuracy of the S2 data is questionable. S2 compounds result from the aliphatic structures of algal cell walls in addition to other biological material. A layer of volcanics associated with the White River Ash Eastern Lobe was observed in both cores. This served as a marker by which the S2 dataset was aligned with the diatom, geochemical and end-member datasets from the other core, PKT_2FR.

For particle size analysis, sub-samples at 1-mm intervals between 3 and $121.3 \mathrm{~cm}$ depth $(n=913)$ in the PKT_2FR2 were pretreated following a protocol derived from Murray (2002) and Van Hengstum et al. (2007). Material from each sub-sample was placed in $30 \% \mathrm{H}_{2} \mathrm{O}_{2}$ solution to oxidize organic matter and were left until reactions ceased. Grain size distributions for 94 grain size classes between 0.4 and $2000 \mu \mathrm{m}$ were then obtained using a Beckman Coulter LS 13320 Laser Diffraction-Particle Size Analyzer at Carleton University. 
End-member mixing analysis (EMMA) was performed on the resulting particle size dataset following the procedure outlined in Dietze et al. (2012; 2014) with the R package, EMMAgeo (Dietze and Dietze, 2016). Only end-members recurring in the majority of model runs that were interpretable and non-overlapping were included in subsequent analyses.

Diatom counts were obtained from 118 samples at $1-\mathrm{cm}$ intervals throughout the core using an Olympus BX51 light microscope with a 100x oil immersion objective (Splan, 1.25). A minimum of 400-600 valves were counted for each sample. Identification of diatom taxa was conducted at the lowest possible taxonomic level with reference to photomicrographs of taxa from similar geographic regions and environments (Krammer \& Lange-Bertalot, 1985-1991; Hartley, 1996; Antoniades et al. 2008).

Absolute values of diatom taxa obtained from each sample were converted to relative abundances to assess changes in assemblage structure. Only taxa present in significant numbers in at least one sample throughout the core were included in the subsequent analysis. Significant taxa were determined using the technique outlined in Patterson \& Fishbein (1989) whereby standard error was calculated for the individual taxon in each sub-sample. The taxon was deemed significant if the relative abundance exceeded the standard error. From the 118 samples with counts, 114 species were identified. Of these, 65 were significant (See Appendix A for table of included taxa).

Hellinger transformed count data of the significant taxa was ordinated through Nonmetric multidimensional Scaling (NMDS) to group samples with similar diatom composition. NMDS was used because it does not assume any environmental gradient relationship (Paliy \& Shankar, 2016). Stratigraphically Constrained Incremental Sum of Squares (CONISS) cluster analysis was also conducted on the Hellinger transformed dataset with the rioja package in 
RStudio with Ward's method using Euclidean distances, to identify stratigraphic zones based on changes in the diatom community composition. This was also based only on significant taxa. Assemblage zones were visually identified using the result from CONISS and NMDS. Redundancy analysis (RDA) was then applied to evaluate the relationship between the diatom Assemblage zones and particle size, Fe/Mn ratio, As, Ca and TSI based on those given by Steinhilber et al. (2009). These parameters were chosen to reflect conditions within the lacustrine environment. The environmental variables for the final RDA model were chosen with the goal of maximizing the variance explained while maintaining the fewest number of significant variables. The variables were determined using an iterative approach whereby the available parameters interpreted to reflect changes in the environmental (major and trace elements, total solar irradiance (TSI; Steinhilber et al., 2009 ), and end-members were added to the model and eliminated if they did not explain more than $\sim 2 \%$ of variance. Although TSI did not meet this criteria, it was included due to its relation to the Pacific Decal Oscillation, a 50-70 year cyclic phenomena where the waters of the northerestern Pacific Ocean shift between warm and cool phases (Gray et al., 2010; Deser et al., 2010). This cyclic phenomenon has been found to influence the climate of the Canadian subarctic (Dalton et al., 2018). The final variables identified were those that did not co-vary with any other variables in the model. Fe and Mn are redox sensitive elements and their relationship has been found to be related to redox conditions within the lacustrine environment (Naeher et al., 2013; Herndon et al., 2018; Żarczyński et al., 2019; Boyle, 2001). Therefore, the Fe/Mn ratio was included as a variable. Spearman's Rank correlation analysis was also applied to the environmental parameter datasets of each assemblage interval to explore changes in the relationships between geochemical, end-member, and TSI variables. Datasets obtained from Rock Eval pyrolysis were not included in the model because it 
was not obtained from the same core and questionable integrity resulting from a lack of material present in the samples that were analyzed.

\begin{tabular}{|llllll|}
\hline & Lab ID & Depth $(\mathbf{c m})$ & $\mathbf{1 4 C}$ age BP $\pm \mathbf{1 \sigma}$ & Pretreatment & Cal BP $\pm \mathbf{2 \sigma}$ \\
\hline PKT_2FR1 & UBA-20676 & $10-10.5$ & $362 \pm 27$ & Acid Only & $\begin{array}{l}500-422(50.7 \%) \\
400-316(44.7 \%)\end{array}$ \\
& & & & Acid Only & $727-653(95.4 \%)$ \\
& UBA-22350 & $20-20.5$ & $731 \pm 31$ & Acid Only & $1302-1239(85.5 \%)$ \\
UBA-20679 & $52-52.5$ & $1335 \pm 25$ & & $1205-1186(9.9 \%)$ \\
& & & & $\mathbf{1 1 1 0} \pm \mathbf{5 0}$ \\
Tephra & $\mathbf{5 5 . 4 - 5 5 . 7}$ & & Acid Only & $1350-1279(95.4 \%)$ \\
UBA-22351 & $57-57.5$ & $1394 \pm 30$ & Acid Only & $1707-1561(95.4 \%)$ \\
UBA-22352 & $70-70.5$ & $1725 \pm 31$ & Acid Only & $3215-3057(93.9 \%)$
\end{tabular}

Table 2.1 Radiocarbon dates obtained from PKT_2FR1. Redrafted with permission from Patterson et al., (2017).

\subsection{Results}

\subsubsection{Sediment Characteristics and End-Member Mixing Analysis}

Four robust end-members were identified through end-member mixing analysis (EMMA). Endmember $1(\mathrm{EM} 1 ; 1.26 \mu \mathrm{m})$ was present at high proportions from the top of the core until about ca. $350 \mathrm{cal}$ yr BP $(19 \mathrm{~cm})$, with later spikes at ca. $650 \mathrm{cal} \mathrm{yr}$ BP $(32 \mathrm{~cm})$ and ca. $1050 \mathrm{cal} \mathrm{yr} \mathrm{BP}$ $(52 \mathrm{~cm})$. Lower increases in EM1 were present only after ca. $2150 \mathrm{cal} \mathrm{yr} \mathrm{BP}(97 \mathrm{~cm})$; prior to this time, EM1 was not present. End-member $2(\mathrm{EM} 2 ; 5.61 \mu \mathrm{m})$ was found throughout the core with low proportions prior to $2150 \mathrm{cal} \mathrm{yr} \mathrm{BP}(97 \mathrm{~cm})$. The pattern for EM2 was highly variable. End-member $3(\mathrm{EM} 3 ; 15.65 \mu \mathrm{m})$ was found throughout the core, and similar to EM2, has a highly variable pattern. This end-member is from ca. $250(15 \mathrm{~cm})$ to ca. $-50(1-8 \mathrm{~cm})$ cal yr BP. 
End-member $4(\mathrm{EM} 4 ; 36.24 \mu \mathrm{m})$ was present from ca. $2650(121.5 \mathrm{~cm})$ to ca. $1850(85 \mathrm{~cm}) \mathrm{cal}$ yr BP and again from ca. $1050(52 \mathrm{~cm})$ to ca. $850 \mathrm{cal} \mathrm{yr} \mathrm{BP}(42 \mathrm{~cm})$, ca. $675 \mathrm{cal} \mathrm{yr} \mathrm{BP}(33.5 \mathrm{~cm})$, and ca. $250 \mathrm{cal}$ yr BP $(15 \mathrm{~cm})$ to present. It was often found in combination with EM1. The stratigraphic profiles of these end-members are presented in Figure 2.4.

Sedimentation rate was found to vary slightly throughout the core (Fig 2.4). In the most basal portion of the core, the sedimentation rate averaged $0.4 \mathrm{~mm} / \mathrm{year}$. This rate was sustained from $2860(130 \mathrm{~cm})$ to $2460 \mathrm{cal} \mathrm{yr}$ BP $(114 \mathrm{~cm})$. Between 2460 and $2260 \mathrm{cal} \mathrm{yr} \mathrm{BP}(103 \mathrm{~cm})$, the sedimentation rate rose from $0.4 \mathrm{~mm} /$ year to $0.6 \mathrm{~mm} /$ year. It remained around this level until $2115 \mathrm{cal}$ yr BP $(95 \mathrm{~cm})$ when the rate returned to $0.4 \mathrm{~mm} / \mathrm{year}$. The sedimentation remained relatively consistent for the next $\sim 1000$ years. Between $1150(55 \mathrm{~cm})$ and $425 \mathrm{cal} \mathrm{yr} \mathrm{BP}(25 \mathrm{~cm})$, the rate increased slightly reaching an average of $0.5 \mathrm{~mm} / \mathrm{year}$. An overall decrease was observed for the remainder of the core reaching a minimum of $0.3 \mathrm{~mm} /$ year at $240 \mathrm{cal} \mathrm{yr} \mathrm{BP}(14 \mathrm{~cm})$.

S2 values from PKT_1FR were aligned with the PKT_2FR datasets based on the depth of the layer of volcanic material associated with the White River Ash Eastern lobe in both cores ( $\sim 35 \mathrm{~cm}$ in PKT_1FR and $\sim 55.7 \mathrm{~cm}$ in PKT_2FR). Due to the limited integrity of the dataset and potential discrepancies between the two cores, $\mathrm{S} 2$ values were only visually analyzed stratigraphically (fig 2.4) and were excluded from statistical analyses. S2 wt\% values ranged between 6.27 and $13.37 \mathrm{wt} \%$ with a median of $10.53 \mathrm{wt} \%$ for PKT_1FR1. Generally, S2 values increased with depth peaking at ca. $2460 \mathrm{cal}$ yr BP $(13.37 \mathrm{wt} \%)$. A gradual, progressive decline in S2 wt \% occured upwards reaching a minimum of $6.23 \mathrm{wt} \%$ at ca. $585 \mathrm{cal} \mathrm{yr}$ BP.

\subsubsection{Diatom Analysis}


The majority of the significant diatom species were benthic. Planktic species were dominated by Cyclotella sensu lato species (Fig 2.5). Although planktic taxa were found in elevated abundance in the most recent sediments, they never made up more than $\sim 25 \%$ of the total diatom population.

Based on visual analysis of the results generated through CONISS and NMDS five diatom assemblages were identified throughout the 118-cm long section of core analyzed: Assemblage 1 (131-103 cm; ca. 2860-2260 cal yr BP; n=28); Assemblage 2 (102-64 cm; ca. 2240-1300 cal yr BP; n=38); Assemblage 3 (63-54 cm; ca. 1280-1090 cal yr BP; n=11); Assemblage 4 (53-40 cm; ca. 1070-815 cal yr BP; $\mathrm{n}=13)$; and Assemblage 5 (39-13 cm; ca. 795190 cal yr BP; $\mathrm{n}=26$ ) (Figs 2.2, 2.4). Throughout the entire interval studied, the minor components (less abundant but diverse species) of the diatom population consistently show the most variation whereas the dominant taxa, Nitzschia spp. and Navicula spp., remained relatively unchanged. The stratigraphic profiles of major taxa are presented in Figure 2.4.

In Assemblage 1 (131-103 cm; ca. 2861-2260 cal yr BP) Nitzschia palea sensu lato (Fig 2.5) was the most common taxon with a zonal median relative abundance of $26 \%$ (range: $13-$ $38 \%, n=28)$. Navicula spp. also made up a large proportion of the diatom population with a median abundance of $17 \%$ (range: $13-22 \% ; \mathrm{n}=28$ ). Navicula cryptotenella was the most abundant single species in this genus with a median abundance of 7\% (range: $2.6-11 \% ; \mathrm{n}=28$ ). Other major constituents of Assemblage 1 were Staurosira venter (median: 11\%; range: $1.2-$ 26\%), Encyonopsis spp. (median: 3\%; range: 1-10\%; n=28), Brachysira microcephala (Fig 2.5) (median: 4\%; range: 1-12\%; $\mathrm{n}=28$ ), and Achnanthidium atomus (median: 11\%; range: 6-17\%; $\mathrm{n}=28$ ). Encyonema minuta (median: 2.9; range: 1-7\%; $\mathrm{n}=28$ ) and Encyonema silesiacum (median: $0.4 \%$; range: $0-2 \% ; \mathrm{n}=28$ ) were also significant, albeit minor taxa in Assemblage 1 . 
Both Encyonema species were found in the basal section of the core, disappearing completely after ca. $1940 \mathrm{cal}$ yr BP $(88 \mathrm{~cm})$. The structure of Assemblage 1 was not stable stratigraphically, and trends in composition are noted. Staurosira venter sharply declined upwards from a maximum of $26 \%$ at ca. $2790 \mathrm{cal} \mathrm{yr} \mathrm{BP}(127 \mathrm{~cm})$ to a minimum of $1 \%$ at ca. $2350 \mathrm{cal} \mathrm{yr} \mathrm{BP}(108$ cm). Conversely, Encyonopsis spp., and Brachysira spp. became more dominant moving upwards in Assemblage 1, increasing from 2\% to $8 \%$ and $3 \%$ to $12 \%$, respectively, between ca. 2840 and ca. $2295 \mathrm{cal} \mathrm{yr} \mathrm{BP}(129 \mathrm{~cm}-105 \mathrm{~cm})$.

Assemblage 2 (102-64 cm; ca. 2240-1300 cal yr BP; n=38) was characterized by decreased abundances of Achnanthidium spp. (median: 10\%; range: 5-16\%; $\mathrm{n}=38$ ) and the disappearance of $S$. venter. Taxa that became increasingly prominent in Assemblage 2 included: Sellaphora spp. (median: 9\%; range: 5-13\%; n=38), Stauroneis spp. (median: 3\%; range: 1-6\%; $\mathrm{n}=38$ ), and Pinnularia spp. (median: 3\%; range: 1-5\%; n=38). Navicula spp. (median: 21\%; range: $14-28 \% ; \mathrm{n}=38$ ) and Nitzschia palea sensu lato (median: 26\%; range: $11-28 \%$; $=38$ ) remain the most abundant groups of taxa (Fig. 2.5).

Assemblage 3 (63-54 cm; ca. 1280-1090 cal yr BP; n=11) was distinguished from Assemblage 2 by a slight increase in the relative abundance of Brachysira microcephala, that reacheed $13 \%$. Nitzschia palea sensu lato remained high in abundance with a median of $23 \%$. Navicula spp. (median: 17\%; range: $15-22 \%$; $=11$ ) also continued to be a major component of the diatom community.

Assemblage 4 (53-40 cm; ca. 1070-815 cal yr BP; n=13) was characterized by elevated abundance of Brachysira microcephala (median: 15\%; range: 10-19\%; $n=13$ ) and an increase in the proportion of Cyclotella spp. sensu lato (median: 5\%; range: 3-10\%; $\mathrm{n}=13$ ). Nitzschia palea 
sensu lato continued to be a major component of the diatom community with a zonal median abundance of $22 \%$.

Assemblage 5 (39-13 cm; ca. 795-190 cal yr BP; n=26) was characterized by an increase in the abundance of Cyclotella sensu lato (median: 18\%; range: 10-28\%; n=26). As a result, the planktic to benthic ratio increased dramatically here (median: $13 \%$; range: $7-24 \%$; $=26$ ).

Navicula spp. (median: 22\%; range: $16-30 \% ; n=26$ ) continued to make up a large proportion of the community. Achnanthidium spp. (median: 6\%; range: 3-11\%; n=26), Brachysira microcephala (median: 16\%; range: 11-20\%; n=26) and Encyonopsis spp. (median: 9\%; range: $5-11 \% ; n=26)$ were also major components of Assemblage 5.

\subsubsection{Bulk sediment geochemistry}

The elements presented here were redox sensitive as those may be indicative of changes in oxygenation within the lake. The basal portion of the Pocket Lake core (131-117 cm; ca. 2860$2535 \mathrm{cal}$ yr BP) was characterized by elevated concentrations of As that ranged up to $278 \mathrm{ppm}$ at ca. $2740 \mathrm{cal}$ yr BP $(125 \mathrm{~cm})$. No clear association was observed between the concentrations of molybdenum and manganese $\left(\mathrm{r}_{\mathrm{s}}=-0.09\right.$ and 0.15 respectively).

Between ca. 2690 and ca. 2535 cal yr BP (123-117 cm), sedimentary As concentrations substantially decrease to $50 \mathrm{ppm}$. This is negatively correlated with $\mathrm{S}\left(\mathrm{r}_{\mathrm{s}}=-0.68\right)$ which increases in concentration from 1260 to $1340 \mathrm{ppm}$ in the same interval.

At ca. 1940-1885 cal yr BP (88-86 cm), the concentration of Mn decreased from 632-596 ppm where as the concentrations of $\mathrm{Ca}$, As and $\mathrm{S}$ remained relatively similar with small increases from 1000-1010 ppm and 29-34 ppm respectively. The concentration of S remained at $1280 \mathrm{ppm}$. In contrast, the concentration of molybdenum decreased from 3.96 to $2.96 \mathrm{ppm}$. 
Between ca. 1855 and 1115 cal yr BP $(86-57 \mathrm{~cm})$ the concentrations of Ca, Mo and Mn decreased from 970-660 ppm, 3.33-2.78 ppm, and 594-395 ppm respectively. Beginning around ca. 1280 cal yr BP $(63 \mathrm{~cm})$ in the Pocket Lake core, sedimentary As concentrations began to increase. This trend was sustained for the remainder of the core and concentrations of As increased to $1668.8 \mathrm{ppm}$ at the top of the interval of study $(13 \mathrm{~cm})$. The bulk concentration of $\mathrm{Ca}, \mathrm{S}$, and Mn also increased at this time (1180 ppm, $1500 \mathrm{ppm}, 500 \mathrm{ppm}$, respectively) although this was not sustained in the way that was observed with arsenic. The concentration of S showed a strong positive correlation with As $\left(\mathrm{r}_{\mathrm{s}}=0.63\right)$. Mo concentrations remain low (1.98 ppm).

At ca. $400 \mathrm{cal}$ yr BP $(21 \mathrm{~cm})$, the concentration of As increased from 876 to $1669 \mathrm{ppm}$. Antimony (Sb) concentrations followed a similar trend and increased from $\sim 15$ to $\sim 40 \mathrm{ppm}$ during the same interval. Concurrently, $\mathrm{Mn}$ and Mo decreased in concentration. The concentration of Ca remains low.

Between ca. 400 and $330 \mathrm{cal} \mathrm{yr} \mathrm{BP}(21-18 \mathrm{~cm}) \mathrm{Ni}$ and Mo increased in concentration, whereas $\mathrm{S}, \mathrm{Pb}, \mathrm{Zn}$, and $\mathrm{Mn}$ decreased. Prior to $\sim 400$ cal yr BP, As and $\mathrm{S}$ followed a similar pattern but in sediments were younger than ca. $400 \mathrm{cal}$ yr BP $(21 \mathrm{~cm})$; however, in the uppermost interval they showd a negative correlation $\left(\mathrm{r}_{\mathrm{s}}=-0.51\right)$. As concentrations continued to increase whereas S concentrations decreased (from $2050 \mathrm{ppm}$ to $1500 \mathrm{ppm}$ ).

Over the past $\sim 400$ years As concentrations sharply increased and peak in the uppermost samples to $1668 \mathrm{ppm}$ (ca. $190 \mathrm{cal}$ yr BP; $13 \mathrm{~cm}$ ). Antimony showed a strong positive correlation with As $\left(\mathrm{r}_{\mathrm{s}}=0.78\right)$ concentrations increasing from 15.1 to $43.6 \mathrm{ppm}$. The notion of down-core smearing of the geochemical signal was rejected here because trends differ for other elements associated with metal mining in the Yellowknife region (e.g., Sb). 


\subsubsection{Redundancy Analysis}

Results from RDA showed relationships of variable significance between the five diatom assemblages and changes in sediment geochemistry, particle size, and TSI (Fig. 2.3). Assemblage 1 showed a strong association with End-Member $3(15.65 \mu \mathrm{m})$ and calcium concentration. Assemblage 2 shows a weak relationship to TSI. There was also no association between Assemblage 2 and calcium concentration (a primary alkalinity anion; Batterbee, 1984). Assemblages 3 and 4 appeared to be associated with changes in oxygenation (Hargrave, 1972; Batterbee et al., 2000), as represented by variations in the Fe/Mn ratio, a parameter influenced by redox conditions (Herndon et al., 2018). The uppermost assemblage coincided with an increase in the concentration of arsenic and RDA analysis plots them in the same Euclidean space. 


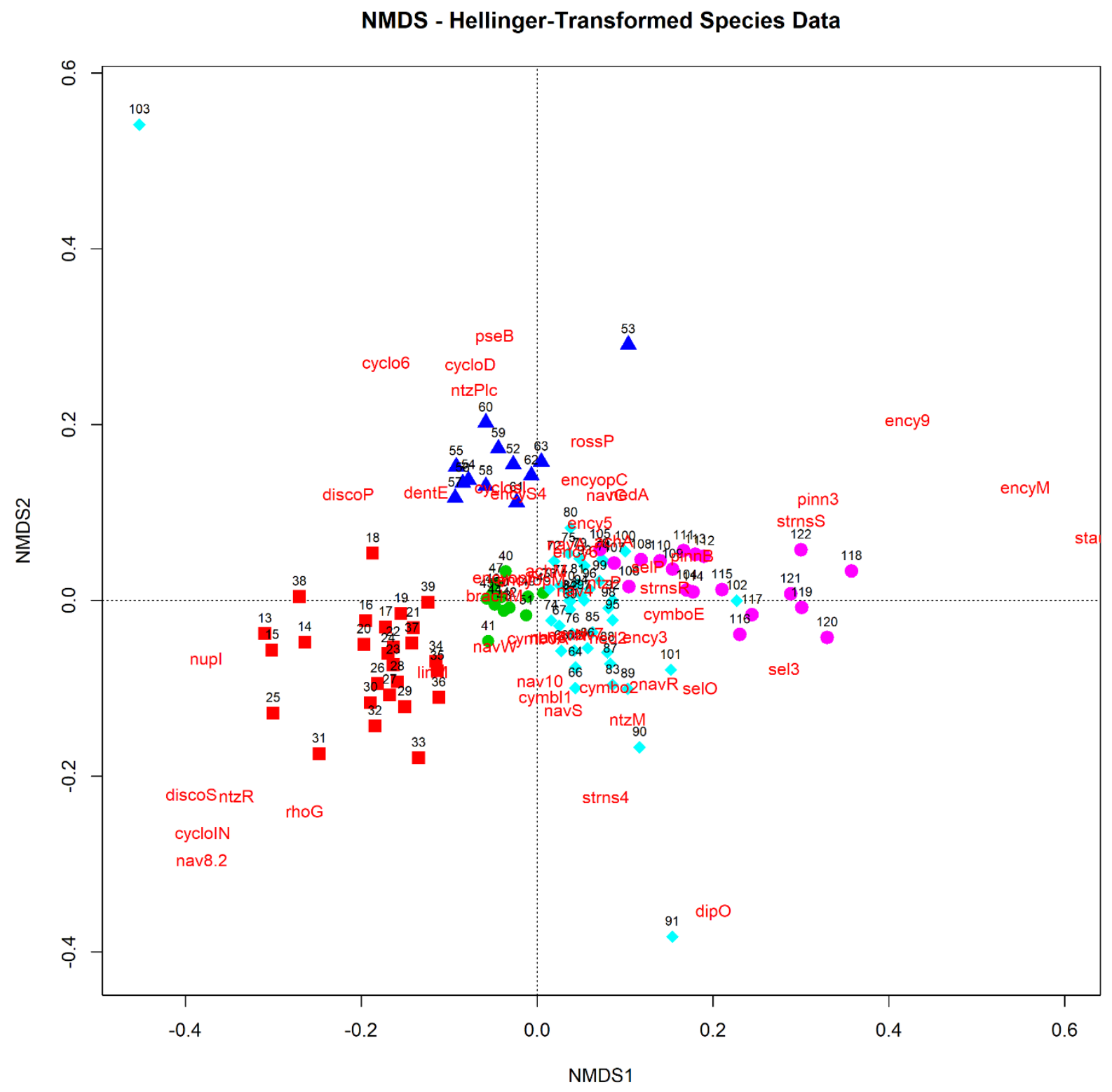

Figure 2.2. Non-metric Multidimensional Scaling analysis. Samples containing a similar diatom composition were grouped. The sample numbers indicate the depth of a given sample. The coloured groups were based on the assemblages inferred through CONISS. Pink $=$ Assemblage 1; Turquoise $=$ Assemblage 2; Dark Blue $=$ Assemblage 3; Green $=$ Assemblage 4; Red $=$ Assemblage 5. Nav=Navicula $;$ Cyclo $=$ Cyclotella $;$ disco $=$ Discotella $;$ nitz $=$ Nitzschia $;$ rho $=$ Rhopalodia $;$ nupl $=$ Nupella $;$ dent $=$ Denticula $;$ brachy $=$ Brachysira $;$ pse $=$ Pseudostaurosira $;$ 
cymbl = Cymbella $;$ cymbo = Cymbopleura $;$ strns $=$ Stauroneis $;$ ency = Encyonema $;$ sel $=$ Sellaphora $; \operatorname{dip}=$ Diploneis $;$ pinn $=$ Pinnularia $;$ sta $=$ Staurosira.
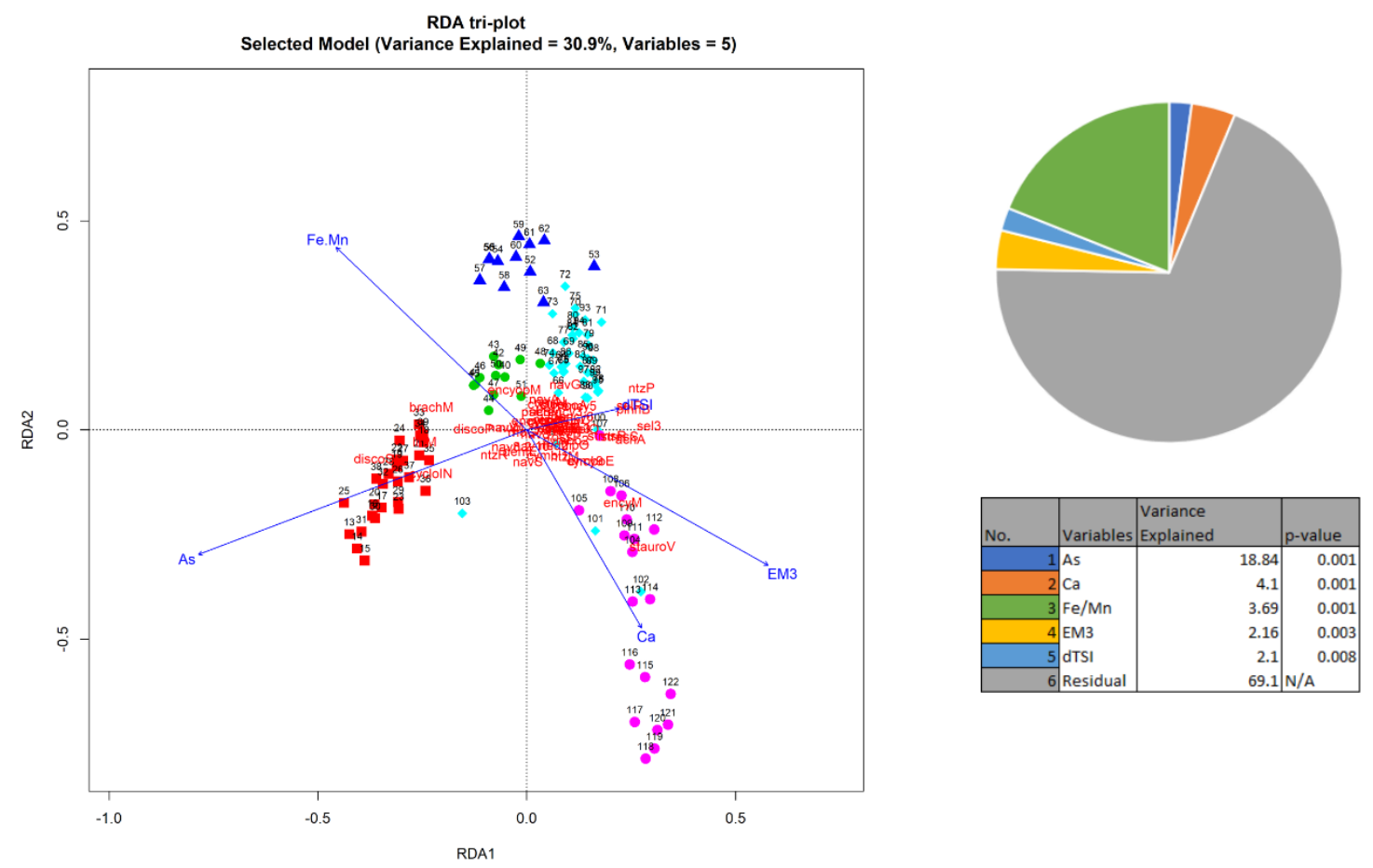

Figure 2.3 RDA tri-plot. Each point represents an individual sample. The numerical value denotes sample depth. Colour groups were based on those determined via CONISS of species data Pink $=$ Assemblage 1; Turquoise $=$ Assemblage 2; Dark Blue $=$ Assemblage 3; Green $=$ Assemblage 4; Red= Assemblage 5. The blue lines represent the different environmental paraments included in the model. The length of the line relates to the variance explained by the variable. $\mathrm{Ca}=$ calcium concentration; $\mathrm{EM} 3=$ end-member 3 frequency; Fe. $\mathrm{Mn}=$ the Fe/Mn value; As $=$ bulk sedimentary arsenic concentration $(\mathrm{ppm})$. The pie chart indicates the variance explained as a percentage for each variable included in the model as well as the residual 
variance. The table provides their numerical values for variance explained and associated $\mathrm{p}$ values.

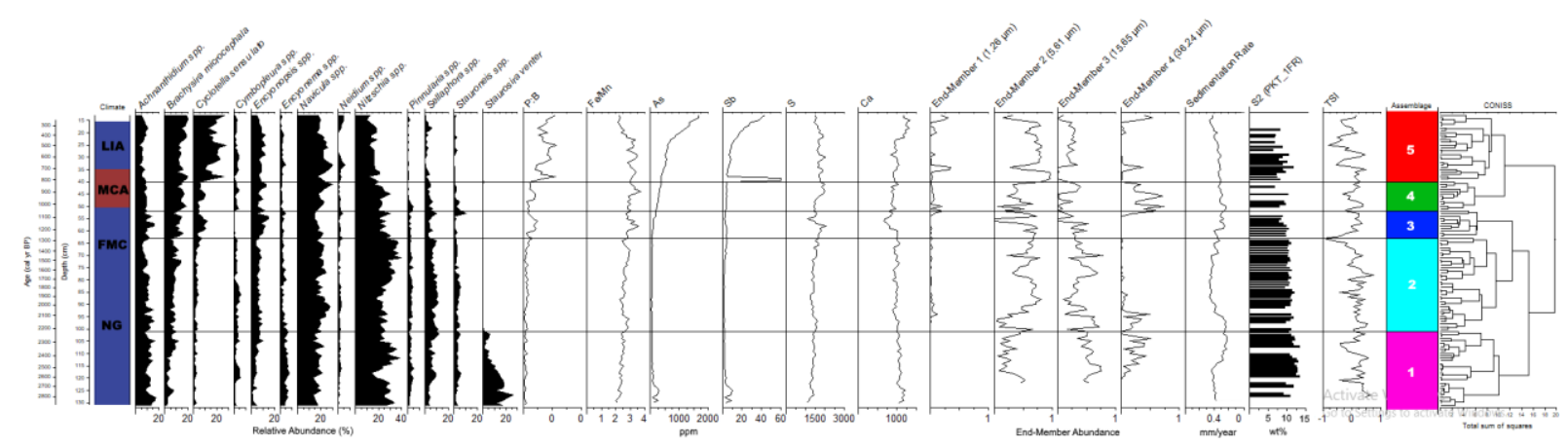

Figure 2.4. Stratigraphic profiles of significant diatom groups and environmental parameters determined by interactive redundancy analysis (RDA) to be important. TSI is calculated based on Steinhilber et al., (2009). S2 values were obtained from PKT_1FR1 and were related to the PKT_2FR1 datasets based on the observed depth of the White River Ash Eastern Lobe tephra layer in each core (35 cm in PKT_1FR1 and $55.7 \mathrm{~cm}$ in PKT_2FR). The column on the left shows the chronology of late Holocene climate events derived from Upiter et al., (2014). Blue indicates cooler periods whereas red indicates relative warming. LIA=Little Ice Age; MCA=Medieval Climate Anomaly; FMC=First Millennial Cooling; NG=Neoglacial. 


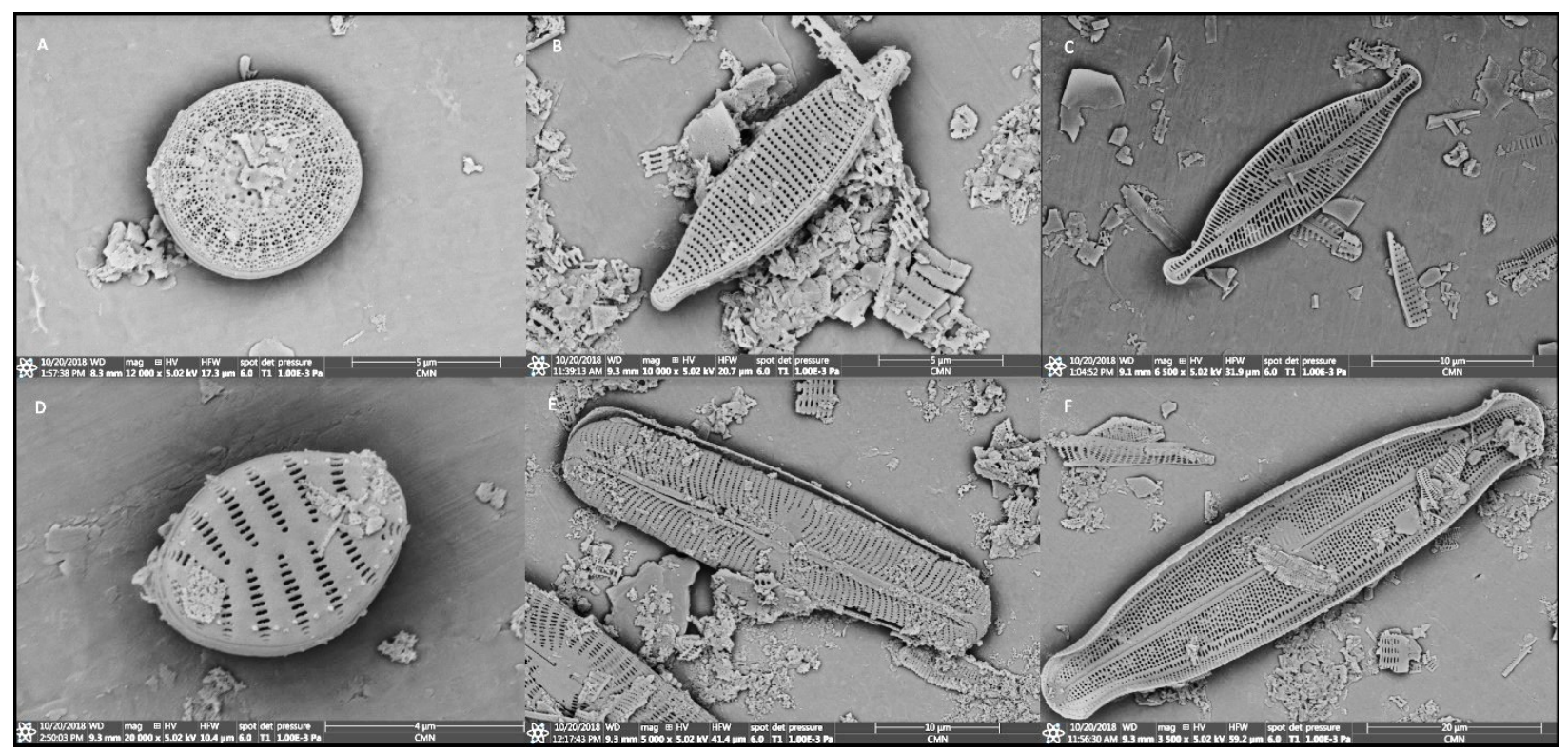

Figure 2.5. SEM Images of key taxa documented in the PKT_2FR2. A=Discotella

pseudostelligera (one of the most common Cyclotella sensu lato taxa); $\mathrm{B}=$ Nitzschia palea;

$\mathrm{C}=$ Brachysira microcephala $; \mathrm{D}=$ Staurosira venter $; \mathrm{E}=$ Sellaphora pupula $; \mathrm{F}=$ Neidium $\mathrm{cf}$. affine.

\subsection{Discussion}

Assemblage 1 shows a significant positive relationship with Ca concentration and EM3 (coarse silt; $15.65 \mu \mathrm{m}$ ). An influx of coarser material is often associated with increased runoff from the catchment and $\mathrm{Ca}$ concentration is often associated with increased alkaline conditions (Batterbee, 1984). The diatom assemblage includes several dominant species associated with cold alkaline waters such as Navicula cryptotenella and, most notably, S. venter. Staurosira venter is an opportunistic species found in alkaline environments and can reproduce rapidly allowing it to be successful in stressed, shifting environments and those with limited growing seasons (Weckström et al., 1997; Lotter \& Bigler, 2000; Bouchard et al., 2004; Smol, 1988; Laing et al., 1999). The species is also commonly associated with cold, unproductive waters and 
is common to tundra lakes in post-glacial settings (Liang et al., 1999). The same authors indicate that peaks in the relative abundance of $S$. venter often coincide with rapidly shifting conditions within the catchment, creating new environments that these taxa can rapidly colonize, providing competitive advantage over other species (Verses et al., 1995).

Although S. venter is sometimes found in treeline lakes, a reconstruction of treeline movement throughout the Holocene presented in Sulphur et al. (2016) indicates that the treeline never migrated south of Pocket Lake. The reconstruction developed by the authors is based on boreal fire regimes derived from lake sediments in Carleton Lake, another lake located within the central NT, north of Pocket Lake. Their reconstruction indicates that both lakes existed within a boreal forest environment during this interval. Moreover, Sulphur et al., (2016) noted an overall reduction in forest fire frequency after ca. $2200 \mathrm{cal} \mathrm{yr} \mathrm{BP}$ which they attribute to a cooler, wetter climate. While the region surrounding Pocket Lake remained forested at this time (Sulphur et al., 2016), conditions would have been relatively cool and associated with the beginning of the Neoglacial, a widespread cool interval in NW Canada (Macumber et al., 2018; Upiter et al., 2014). It is possible that cooler conditions increased seasonal ice cover and limited periphytic diatoms such as $S$. venter allowing for the insurgance of other species. The disappearance of $S$. venter, and other alkaliphile species coupled with the increase in warm water diatoms upwards could be indicative of a transition to warmer temperatures and less alkaline water conditions. Compared with the succeeding intervals, As concentrations in the most basal portion of the core are relatively high (up to $275 \mathrm{ppm}$ at ca. $2740 \mathrm{cal}$ yr BP). An overall decline in As concentration is observed between ca. $2840 \mathrm{cal} \mathrm{yr} \mathrm{BP}$ to ca. $2510 \mathrm{cal}$ yr BP. Declining As in nonanthropogenically impacted lakes could be related to a decline in productivity associated with cooler conditions (Galloway et al., 2018). 
The shift to Assemblage 2 is characterized by a general increase in large, benthic species notably: Sellaphora spp., Cymbella spp., and Stauroneis spp.. The increased abundance of these taxa suggests a period of warming as well as slightly more productive conditions within Pocket Lake (Szczepocka and Szulc, 2009). In addition, there is an increase in the proportion of larger benthic diatoms potentially indicating a shift to more stable and productive littoral conditions favoring the development of a larger benthic population. Evidence for lower alkalinity is also indicated by the reduced abundance of Alkaliphile diatoms such as S. venter and N. cryptotenella with the former disappearing entirely. RDA results do not show a strong association between calcium concentration as a proxy for paleo-alkalinity, and Assemblage 2. Large benthic species favouring warmer conditions and clear waters are more abundant at the base of Assemblage 2 and decrease upward. The decrease in warm water, benthic species suggests that there may have been an initial climatic warming followed by a long, sustained cool period. Recent paleoclimatic reconstructions for the NT indicate an overall, sustained cool period after $2200 \mathrm{cal}$ yr BP (Sulphur et al., 2016; Macumber et al., 2018; Upiter et al., 2014). The increase in warm-water taxa such as Sellaphora spp. followed by a sustained decline in abundance suggests that there was a short-lived warm period that punctuated an overall, cooler climate regime. An increase in modelled sedimentation rate is also sustained over the time period represented by Assemblage 2 . An increase in sedimentation may have also contributed to the increase in taxa favoring more productive conditions as more nutrients may have been introduced from the catchment. Collectively, these factors suggest that after an initial climatic shift, conditions within the catchment stabilized.

Shifting redox conditions may be indicated by an association between Assemblage 3 and the Fe/Mn ratio. The calculated sedimentation rate also substantially decreases during deposition 
of Assemblage 3, possibly reflecting less allocthonous input as a result of less runoff from the catchment. This is also supported by a decrease in EM3 $(15.65 \mu \mathrm{m})$ and EM4 $(36.24 \mu \mathrm{m})$, with a coeval increase in EM2 $(5.61 \mu \mathrm{m})$ Small planktic diatoms particularly, Cyclotella intermedia and Cyclotella distinguenda become slightly more abundant in Assemblage 3. The timing of Assemblage 3 broadly coincides with the First Millennial Cooling, that was a widespread cooling interval centered around ca. $1400 \mathrm{cal}$ yr BP (Upiter et al., 2014). A decrease in the abundance of warm water taxa such as the Sellaphora spp. also provides evidence for cooler temperatures. It is possible that a cooler period resulting in a longer duration of seasonal ice cover could have influenced precipitation and erosion from the catchment impacting nutrient and clastic input from the catchment (Scheffer et al., 2007; Dietze et al., 2012; 2014). Changes in oxygenation within the lake can be derived from a shift in redox conditions which may have influenced the development of Assemblage 3. Cooler conditions may also have influenced nutrient input from the catchment due to changes in overland hydrology thereby driving changes in diatom assemblage (Neff et al., 2008). Further evidence for a change in redox conditions can be observed in the relationship between Mo and S (Brahney et al., 2007). Under reducing conditions, Mo and S can be incorporated into pyrite. Therefore, a positive relationship between concentrations can provide evidence for this process. A strong positive correlation is seen between $\mathrm{S}$ and Mo during this interval $\left(\mathrm{r}_{\mathrm{s}}=0.79\right)$ thereby suggesting a reducing environment (Brahney et al., 2007) between ca. 1280 and ca. $625 \mathrm{cal}$ yr BP $(63-31 \mathrm{~cm})$ in Pocket Lake. The positive S-Mo relationship in the sediments of Pocket Lake, suggests that a shift from oxic to reducing conditions occurred in the hypolimnion. The strong, positive relationship observed during this interval suggests that the lake was better oxygenated prior to ca. 1280 cal yr BP (63 $\mathrm{cm}$ ) than the succeeding interval. The timing of this shift roughly coincides with the shift from 
Assmblage 3 to Assemblage 4. Decreased oxygenation in the uppermost sediments could therefore have impacted the diatom composition, particularly benthic varieties. Cooler conditions may have also led to the decreased abundance of taxa favouring warmer conditions such as Sellaphora pupula sensu lato (Fig 2.5) and Stauroneis spp. (Le Blanc et al., 2004).

In Assemblage 4, a further increase in the relative abundance of acidophile diatoms (e.g., E. microcephala, B. microcephala) occurs as does an increase in planktic species, particularly $D$. pseudostelligera and $C$. distiguenda. The shift toward more a more planktic diatom population, indicated by an increase in the planktic to benthic ratio from a median of 0.007 (ca.1770-1300 cal yr BP; 82-64 cm) to a peak of 0.078 at ca. $1090 \mathrm{cal} \mathrm{yr} \mathrm{BP}(54 \mathrm{~cm})$, coincides with an increase in sedimentation rate and an increase in the predominance of the coarsest End-Member 4 (36.24 $\mu \mathrm{m})$. Together, these suggest increased in runoff from the catchment that delivered coarser material to Pocket Lake. Arsenic concentration also begins to gradually increase at this time. Studies in the Yellowknife region have indicated that arsenic concentration may be associated with organic matter (Galloway et al., 2018). Further evidence for an increase in productivity is seen in an increase in diatoms favouring mesotrophic environments such as Brachysira microcephala (Fig 2.5) and Neidium spp. (Fig 2.5) (Siver et al., 2005). Warm water species such as Sellaphora spp., and Stauroneis spp. also become more prominent in Pocket Lake. An increase in sedimentation, coarser material, and a transition taxa indicative of mesotrophic conditions suggest that a warmer climate prevailed and may have affected overland hydrology within the catchment, that ultimately resulted in an influx of sediment and nutrients that in turn led to an increase in productivity (Scheffer et al., 2007).

Interpreted RDA results show a strong relationship between the fifth assemblage and As concentration of bulk sediments, that increases to $>1000 \mathrm{ppm}$ in the upper $20 \mathrm{~cm}$ of the core. Sb 
concentrations also increase concurrently. Because $\mathrm{Sb}$ is not as mobile post-depositionally as As (Leuz et al., 2006; Ritchie et al., 2013), similar trends between the two elements in this portion of the core may indicate a geogenic source. Both $\mathrm{Sb}$ and As are found in elevated concentrations in mineralized zones in the area surrounding Pocket Lake (Fawcett et al., 2015), so an coeval increase in $\mathrm{As}$ and $\mathrm{Sb}$ could be driven by increased erosion from the surrounding host rock. A strong positive relationship is observed between the trends in concentration for As and $\mathrm{Sb}$ $\left(\mathrm{r}_{\mathrm{s}}=0.78\right)$. Additionally, the concurrent change in relationship between redox sensitive elements Mo and Fe/Mn suggests a potential shift in redox conditions within the lake $\left(\mathrm{r}_{\mathrm{s}}=0.31\right.$ between $1070-815$ ca. cal yr BP [53-40 cm] to 0.07 for $795-190$ ca. cal yr BP [40-13 cm]). The relationship between Mo and S that was previously observed decreases in significance which could be indicative of a shift away from reducing conditions $\left(\mathrm{r}_{\mathrm{s}}=0.55\right.$ to $\left.\mathrm{r}_{\mathrm{s}}=0.38\right)$. This could potentially led to better oxygenation within the bottom waters of the lake (Hargrave, 1972). Diatom species commonly associated with acidic environments such as B. microcephala and Neidium spp. became common at after ca. $1020 \mathrm{cal} \mathrm{yr}$ BP $(40 \mathrm{~cm})$, indicating a period of elevated acidity (Siver et al,. 2005). The increase in As concentration as well as diatoms favouring nutrient enriched conditions may indicate a continuation of the trend towards elevated productivity. Prior to ca. $625 \mathrm{cal}$ yr BP $(31 \mathrm{~cm})$, As and S shared a strong positive association $\left(\mathrm{r}_{\mathrm{s}}=0.8\right)$. This pattern breaks down above ca. $625 \mathrm{cal}$ yr BP $(31 \mathrm{~cm})$ with a negative relationship between As and $\mathrm{S}$ appearing $\left(\mathrm{r}_{\mathrm{s}}=-0.51\right)$. As continues to increase whereas $\mathrm{S}$ concentration peaks at $2050 \mathrm{ppm}$ (ca. $603 \mathrm{cal} \mathrm{yr} \mathrm{BP;} 30 \mathrm{~cm}$ ) and decreases to $1500 \mathrm{ppm}$ at ca. $190 \mathrm{cal} \mathrm{yr} \mathrm{BP}(13 \mathrm{~cm})$ potentially indicating that the shift in redox conditions did not exert a significant control over the observed As concentration after ca. $625 \mathrm{cal}$ yr BP (Smedley and Kinniburgh, 2002). A recent study by Theinpont et al., (2016) found As concentrations upwards of $10,000 \mathrm{ppm}$ in $20^{\text {th }}$ century 
sediments resulting from mining activity. The elevated As concentrations found in older sediments from the lake, deposited prior to development in the region, indicate that geogenic As contaminations were present in Pocket Lake prior to anthropogenic activity. An increase in coarse material indicated by a sharp increase in the proportion of EM4 $(36.24 \mu \mathrm{m})$, is also apparent. Influx of coarser material may be indicative of increased runoff form the catchment (Macumber et al., 2018). The sustained sediment input potentially could have caused waters to remain turbid, thereby limiting light penetration. Decreased light penetration would have limited development in the benthic community which could be partially responsible for the apparent shift towards a more planktic population.

The interval occupied by Assemblage 5 broadly coincides with the timing of the Little Ice Age (550-250 cal yr BP; Mann et al., 2009; Upiter et al., 2014). The Little Ice Age was characterized by colder conditions, which is seemingly contradicted by the substantial enrichment of small, planktic Cyclotella spp. sensu lato, notably Discotella stelligera. Often an enrichment of small planktic taxa is indicative of warmer temperatures as a longer growing season would also have allowed for a larger planktic community to develop (Saros and Anderson, 2004). However, this inference of warmer conditions is not consistent with development of regional climate cool conditions associated with the Little Ice Age which would likely have increased the duration of ice cover thereby inhibiting the development of a significant planktic population (Saros and Anderson, 2004; Cremer et al., 2001). Seemingly contradictory enrichment of Cyclotella sensu lato spp. during cool periods is observed in many lakes in similar, high-latitude settings (Cremer et al., 2001; Laing et al., 1999; Kling and Håkansson, 1988; Gregory-Eaves et al. 1999; Ruhland and Smol 2002). The consistent seemingly incompatible increase in S. venter and a shift to cooler, drier conditions seemingly incompatible 
trend suggests that the increase in these taxa was not related with warmer temperatures. Cyclotella sensu lato spp. are documented frequently in chemically dilute Arctic lakes (KarstRiddoch et al., 2005; Gregory-Eaves et al. 1999; Ruhland and Smol 2002). A shift towards colder, drier climate conditions associated with the Little Ice Age could possibly have influenced nutrient input into the lake, either due to changes in precipitation or vegetation in the catchment (Laing et al., 1999; Saro and Anderson, 2015; Neff et al., 2008; White and Blum, 1995). The abundance of $D$. stelligera is also found to be negatively impacted by alkalinity. It is possible that a decrease in alkalinity could be favouring the development of a large $D$. stelligera population (Saros and Anderson, 2015; Laing et al., 1999). The increase in As coeval to an increase in D. stelligera is also seemingly in contradiction with phenomena in the same lake. Thienpont et al., (2016) investigated the diatom response to mining in Pocket Lake. The authors found that $D$. stelligera disappeared almost entirely coincident with an increase in anthropogenic As. However, in this instance the increase in As was also associated with an influx of heavy metal contaminants (Thienpont et al., 2016) potentially indicating that As did not exert a control over the abundance of $D$. stelligera. Although the driving force behind the apparent increase in these taxa during this period is not clear, it is apparent that conditions within the lake dramatically shifted here emphasizing the sensitivity of lakes in these settings.

\subsection{Conclusions}

Five diatom assemblages are recognized in a sediment core from Pocket Lake over the past $\sim 2800$ years. Redundancy analysis was used to evaluate the relationship between diatoms, and proxies used to assess potential drivers of paleolimnological change (TSI, sedimentary 
grains size, major and trace element concentrations). The first assemblage was dominated by diatom taxa indicative of alkaline waters, namely, S. venter. This taxon had a strong relationship between one of the coarser end-members (EM3; $15.65 \mu \mathrm{m})$ and Ca. Together, the assemblage and geochemical data indicates that between ca. $2860 \mathrm{cal} \mathrm{yr} \mathrm{BP}$ and ca. $2260 \mathrm{cal} \mathrm{yr} \mathrm{BP,}$ conditions were cooler and alkaline. The following assemblage was characterized by an increase in the abundance of larger, benthic diatoms and a small increase in sedimentation rate. This was the longest-sustained assemblage and persisted for almost 1000 years. In the lower portion of this interval, large benthic taxa favouring warmer waters increased in abundance followed by a slow decline. This suggests that a short-lived warming was followed by a long-lasting trend towards cooler waters. A long period of relatively stable conditions may also have allowed larger, less adaptive taxa to appear in significant numbers. This was followed by two assemblages in which stress-indicator diatoms became prevalent once again. Shifting redox conditions as well as increased productivity were likely drivers. Evidence for this was provided by the increase in taxa favouring acidic and more nutrient enriched waters. The uppermost assemblage coincided with a further increase in planktic varieties as well as a sharp increase in arsenic concentration. Although this pattern is often associated with warmer conditions, this assemblage zone is contemporaneous with the timing of the Little Ice Age, when colder drier conditions prevailed. As this contradictory dominance of $D$. stelligera and a colder climate is apparent in many other northern lakes, it is clear that factors other than temperature are driving this shift. These results illustrate the sensitivity of subarctic lakes to changes in regional climate and provide insight into their potential response to future climatic variation. 


\section{Chapter 3: Diatom ecological response to deposition of the 833-850 CE White River Ash (east lobe) ashfall in a small subarctic Canadian lake}

Scott J. Hutchinson ${ }^{1}$, Paul B. Hamilton ${ }^{2}$, R. Timothy Patterson ${ }^{1}$, Jennifer M. Galloway ${ }^{3}$, Nawaf A. Nasser $^{1}$, Christopher Spence ${ }^{4}$, Hendrik Falck ${ }^{5}$

${ }^{1}$ Ottawa-Carleton Geoscience Center and Department of Earth Sciences, Carleton University, Ottawa, Ontario, K1S5B6 Canada

${ }^{2}$ Research Division, Canadian Museum of Nature, Ottawa, ON, K1P 6P4, Canada

${ }^{3}$ Geological Survey of Canada Calgary/ Commission Géologique du Canada, Calgary, Alberta, T2L 2A7, Canada

${ }^{4}$ Environment and Climate Change Canada, 11 Innovation Boulevard, Saskatoon, SK, S7N 3H5, Canada

${ }^{5}$ Northwest Territories Geological Survey, P.O. 4601-B 52 Avenue Yellowknife, NT X1A 2L9, Canada 


\subsection{Abstract}

A $<5 \mathrm{~mm}$ thick volcanic ashfall layer associated with the White River Ash (east lobe [WRAe]) originating from the eruption of Mount Churchill, Alaska (833-850 CE; 1117-1100 cal BP) was observed in two freeze cores obtained from Pocket Lake $\left(62.5090^{\circ} \mathrm{N}, 114.3719^{\circ} \mathrm{W}\right)$, a small subarctic lake located within the city limits of Yellowknife, Northwest Territories, Canada. Here we analyze changes in diatom assemblages to assess impact of tephra deposition on the aquatic biota of a subarctic lake. In a well-dated core constrained by 8 radiocarbon dates, diatom counts were carried out at 1-mm intervals through an interval spanning $\sim 1 \mathrm{~cm}$ above and below the tephra layer with each $1 \mathrm{~mm}$ sub-sample represented about 2 years of deposition. Non-metric Multidimensional Scaling (NMDS) and Stratigraphically Constrained Incremental Sum of Squares (CONISS) analyses were carried out and three distinct diatom assemblages were identified throughout the interval. The lowermost "Pre-WRAe Assemblage (Pre-WRAeA)" was indicative of slightly acidic and eutrophic lacustrine conditions. Winter deposition of the tephra layer drove a subsequent diatom flora shift to the "WRAe Assemblage (WRAeA)" the following spring. The WRAeA contained elevated abundances of taxa associated with oligotrophic, nutrient depleted and slightly more alkaline lake waters. These changes were only apparent in samples within the WRAe containing interval indicating that they were short lived and only sustained for a single year of deposition. Immediately above the WRAe horizon, a third, "Post-WRAe Assemblage (PostWRAeA)" was observed. This assemblage was initially similar to that of the Pre-WRAeA but gradually became more distinct upwards, likely due to climatic patterns independent of the WRAe event. These results suggest that lacustrine environments are sensitive to perturbations such as deposition of ash fall, but that ecological communities in subarctic systems can also have high 
resilience and can recover rapidly. If subsampling of the freeze cores was carried out at a more standard resolution $(0.5-1 \mathrm{~cm})$ these subtle diatom ecological responses to perturbation associated with the WRAe depositional event would not have been observed. This research illustrates the importance of high-resolution subsampling when studying the environmental impact of geologically "near instantaneous" events such as episodic deposition of ashfalls. 


\subsection{Introduction}

Plinian-style volcanic eruptions eject a massive amount of ash into the upper atmosphere. Although rare, these events can present a hazard over a large geographic area and have the potential to impact both societies and environmental systems (Walker and Croasdale, 1971). Significant input of ash into the atmosphere can also impact air quality and elicit changes in global climate (Robock and Mao, 1995). Lacustrine environments are particularly susceptible to such events as the deposition of tephra has the potential to radically alter conditions in a lacustrine environment. For example, previous studies have found that depending on composition of the tephra and lake sediments, dissolution of the tephra can potentially result in lake acidification or a large increase in dissolved silica, which may alter a lake's ecosystem and its ecosystem services (Telford et al., 2004). The introduction of ash into the water column of a lake can also impact water clarity and light penetration, which can impact biological productivity, including marcophyte growth (Abella, 1988; Urrutia et al., 2007).

Due to typically long intervals between Plinian eruptions, modern environmental monitoring is unlikely to be useful for accurately predicting the potential impact of episodic ashfalls (Tilling and Lipman, 1993). Therefore, data pertaining to their ecological impact must be obtained from available proxies. In northern Canada, lake sediments are well suited to fill this role due to their abundance and distribution, the diverse proxies they contain, and the near-continuous archives they provide. Variables related to regional environment and climate such as sedimentation rate, vegetation, precipitation, and bedrock composition influence water quality (e.g. pH, salinity, 
light penetration, nutrient concentration), which can be recorded in various proxies preserved in lake sediments (Batterbee, 2000). Diatoms preserved in lake sediments are particularly useful for reconstruction of past ecological change in northern North America due to their ubiquitous distribution, sensitivity to environmental change, and generally good preservation in lake sediments (Dixit et al., 1992). Diatoms make up a large proportion of the primary producers in most lakes and are a major contributor to carbon fixation (Smetacek, 1999). As a result, they play a key role in energy transfer and nutrient cycling between different trophic levels thereby strongly influencing the overall ecology in a lake (Brett and Muller-Navarra, 1997). Different taxa occupy narrow ecological optima and even small changes in water quality can elicit an observable response in the relative proportions of different species within a population. Differences in the diatom assemblages before and after deposition of tephra can indicate changes in the aquatic environment that resulted from tephra deposition (Dixit et al., 1992). Therefore, establishing a connection between changes in the diatom community and deposition of air fall tephra would provide an effective method for assessing water quality impacts of long-range ash-fall associated with Pliniantype volcanism and provide insight into the potential aquatic ecosystem response to future events. Investigating the diatom response to these events also allows for a more comprehensive understanding of the factors controlling the distribution of different diatom species. This allows for the specific changes in populations to be linked to changes in the lacustrine environment allowing higher quality paleoenvironmental reconstructions to be developed leading to more accurate predictions of future changes and events.

A 3-5 $\mathrm{mm}$ thick layer of volcanic tephra was observed in two freeze cores collected in 2012 from Pocket Lake $\left(62.5090^{\circ} \mathrm{N}, 114.3719^{\circ} \mathrm{W}\right)$, a small subarctic lake located within the city limits of Yellowknife, Northwest Territories, Canada. This material was previously identified as 
part of the White River Ash Eastern Lobe (WRAe), which was deposited following the eruption of Mount Churchill, Alaska (1117-1100 cal BP; Patterson et al., 2017). The Pocket Lake deposit represents the only known occurrence of the WRAe in central NWT. The closest known WRAe deposit in a peatland setting is $\sim 100 \mathrm{~km}$ to the west and the nearest lacustrine accumulation is $\sim 470$ km northwest (Robinson, 2001).

Although several studies have evaluated the algal ecological response to air fall tephra into lacustrine environments (Harper et al., 1986; Lotter et al., 1992; Lotter and Birks, 1993; Hickman and Reasoner, 1994; Hickman and Reasoner, 1998; Lotter et al., 1998; Eastwood et al., 2002 ; Barker et al., 2003; Telford et al., 2004; Cruces et al., 2006; Urrutia et al., 2007; Jovanovska et al., 2016) little data is available for the impact of episodic tephra deposition in lakes in subarctic regions Ash layers reported previously in the literature are also generally at least an order of magnitude thicker than the one observed in Pocket Lake (Harper et al., 1986; Lotter and Birks, 1993; Lotter et al., 1994; Hickman and Reasoner, 1994; Jovanovska et al., 2016). Ecological response of lacustrine systems to ashfall varies considerably, from no observed impact to considerable influence on diatom assemblages, making it difficult to identify causal relationships. The difference in response is likely related to the influence of various confounding variables (e,g., lake morphology, ash lithology, lake sediment composition, water chemistry, pre-existing lake ecology), all of which will influence the species makeup of the diatom assemblages (Lotter and Birks, 1993). The identification of a thin WRAe unit in two cores from Pocket Lake provides a unique opportunity to assess the ecological response of diatoms to the deposition of tephra in a small, subarctic lake. The primary objectives of this study are thus to: 
- Evaluate at high temporal resolution $(1 \mathrm{~mm}=\sim 2$ years $)$ the ecological sensitivity and rate of recovery of diatom communities in Pocket Lake following perturbation of the lacustrine system by the WRAe ash fall;

- Compare the WRAe-driven ecological response of the diatom assemblage in Pocket Lake with previously published data from other lacustrine environments impacted by the deposition of ashfall tephra to better understand how confounding variables influence the response of primary producers in aquatic ecosystems and their impact on overall lake ecology.

\subsection{The Mount Churchill Eruptions and the White River Ash}

The WRA depositional plumes were derived from two eruptions of Mount Churchill and distributed in two spatially distinct lobes. The older ca. 1900 cal BP lobe extended north-south, parallel to the Yukon-Alaska border, while the younger WRAe lobe, dated at ca. 1117-1100 cal BP (833-850 CE), was much larger and extended east-west (Lerbekmo et al., 1975). The latter was the source of the material observed in Pocket Lake (Patterson et al., 2017). The WRAe eruption ejected tephra with a calculated volume of $47 \mathrm{~km}^{3}$ making it one of the largest known Plinian style eruptions during the Holocene (Lerbekmo, 2008). Deposits of the WRAe vary in thickness from $0.5 \mathrm{~m}$ to only a few millimeters at more distal locations (Robinson, 2001; Lerbekmo, 2008; Patterson et al., 2017).

The orientation of each WRA lobe was likely correlated with the prevailing seasonal wind patterns during each eruption (Hanson, 1965; West and Donaldson, 2002). Convincing evidence presented in several previous studies indicates that the eastward oriented WRAe eruption most 
likely occurred during late fall and winter, as winds in Alaska tend to trend eastward during winter (West and Donaldson, 2002). Winter emplacement of this tephra is also supported by the presence of anomalous steeply oriented deposits throughout the region (Hanson, 1965). Deposition of this type can only occur when concentrations of ash become compacted under snow, as rain during warmer seasons of the year would have quickly dispersed the ash (Lerbekmo and Cambell, 1969). Moreover, West (2007) analyzed the stratigraphy of two deposits of the WRAe along Bock's Brook and Danjek River in the Yukon Territory where deposition occurred onto a floodplain and concluded that the eruption probably occurred in the late fall-early winter, just prior to the first snowfall but when seasonal temperatures remained consistently below freezing. At Bock's Brook, the ash is preserved as a distinct layer overlain by a gravel unit with no visible reworking of sediment, suggesting that the ash froze in place immediately after deposition. The ash was subsequently buried during the following spring freshet when flood sediments buried and protected the WRAe deposits from being reworked. At Djenek River, West (2007) observed intact clasts of pumice embedded within the fluvial sediments deposited by the river, a type of deposition which requires frost in order to occur. As with the previous site, this material would have remained frozen until the spring. Spring flooding may have then caused the frozen ash layer to fracture, thereby causing the clasts to become embedded within the fluvial silt. The clasts remained intact, which indicated that they were frozen during fragmentation and transport, otherwise signs of abrasion would have been observed. Due to freezing temperatures and associated ice cover of the lake at the time of deposition, ash materials preserved in the Pocket Lake core were most likely delivered into the lake basin during two phases: the first occurring rapidly during the spring snow melt from the immediate lake area, and; the second being introduced gradually from watershed runoff during the following months. 


\subsection{Study Site}

Pocket Lake $(62.5090 \mathrm{~N}, 114.3719$ W) is a subarctic lake within the City of Yellowknife, Northwest Territories (NWT), Canada. It is a small headwater lake within the southern portion of the Baker Creek watershed. The catchment of Pocket Lake (Fig. 3.1) is less than 5 ha, with outcropping bedrock that drains south into the lake via a soil-filled valley (Spence, 2006). A recent study identified a layer of tephra in two cores collected from Pocket Lake (Patterson et al., 2017). The layer is composed of white-coloured ash forming a band 3-5 mm thick. Based on ${ }^{14} \mathrm{C}$-derived age models, stratigraphy, shard morphology and the geochemical signature of the material, obtained through wavelength dispersive X-ray analysis at Carleton University, the tephra layer was identified to be the White River Ash Eastern Lobe (WRAe). Cryptotephra associated with the WRAe have been recorded in lakes in Newfoundland, Greenland, and even as far east as Poland (Jensen et al., 2014; Watson et al., 2016b). The occurrence of the WRAe in Pocket Lake represents the easternmost recorded macroscopic deposit and is the first reported occurrence of the WRAe in a lacustrine environment from the central NWT (Patterson et al., 2017). 


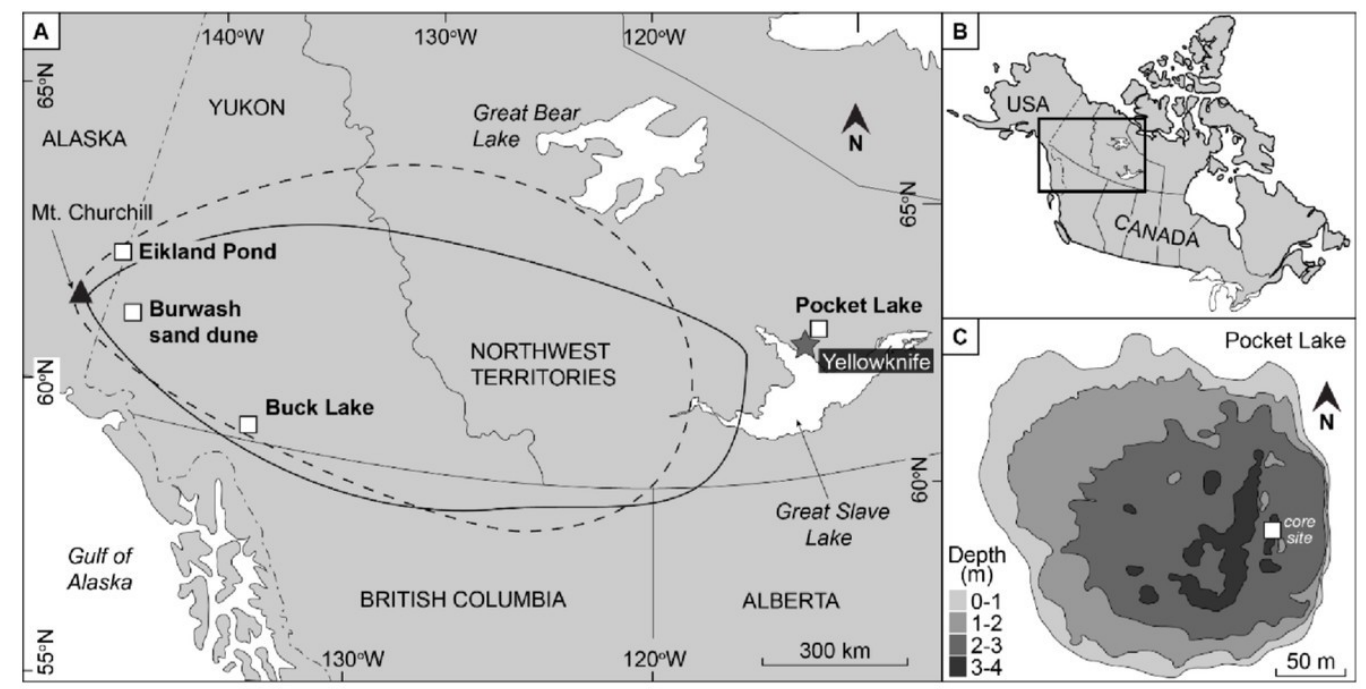

Figure 3.1 The location of the study site relative to Mount Churchill with the WRAe extent given by Lerbekmo (2008; dashed line) and by Robinson2001; solid line). Eilkland Pond, Burwash sand dune, and Buck Lake indicate locations where the WRAe had previously been documented. The previously collected data from these two locations provided a reference with which the geochemical signal of the material in Pocket Lake was compared. Redrafted after Patterson et al. (2017).

\subsection{Methods}

Two cores, approximately $3 \mathrm{~m}$ apart, were collected from Pocket Lake during winter 2012 and provided the material used in this study (Fig. 3.1). The cores, named PKT_1FR and PKT_2FR1, were composed primarily of massive gyttja-type mud. They were collected using a freeze corer, which uses dry ice to freeze to sediment cores in situ to reduce the risk of homogenization of soupy sediment-water interface material and permitted extremely high-resolution sub-sampling 
(Galloway et al., 2010; Macumber et al., 2011). Sub-sampling of cores PKT_1FR and PKT_2FR1 was conducted using a custom sledge microtome (Macumber et al., 2011) at intervals of $1 \mathrm{~mm}$ to $1 \mathrm{~cm}$ throughout their lengths. The first core (PKT_2FR1) was $131 \mathrm{~cm}$ long, while the second core (PKT_1FR) was $180 \mathrm{~cm}$ long. The sediment-water interface was not captured in core PKT_1FR; core PKT_2FR1 was therefore used for detailed study. The tephra appeared as a thin band of white material spanning 55.4-55.7 $\mathrm{cm}$ depth and was visible upon coring. The intact cores were inspected under X-ray and the images generated did not indicate any substantial bioturbation/mixing throughout the interval used here. The contact between the WRAe and the surrounding sediments was sharp and unbroken. Contiguous 1-mm sub-samples from 54.5 to 56.4 $\mathrm{cm}$ spanning an interval from $1 \mathrm{~cm}$ above to $1 \mathrm{~cm}$ below the tephra layer in core PKT_2FR1 were prepared for diatom analysis.

Sub-sampled material was placed in individual centrifuge tubes and freeze dried. Aliquots of $10 \mathrm{mg}$ from each tube were placed in individual beakers. Then $10 \mathrm{ml}$ of concentrated sulfuric $\left(\mathrm{H}_{2} \mathrm{SO}_{4(\mathrm{aq})}\right)$ and nitric $\left(\mathrm{HNO}_{3}(\mathrm{aq})\right)$ acid solution containing both in equal proportions was added and heated to digest organic material. Following digestion, the acid was diluted and removed through centrifugation dilution, and this was repeated 5 times. A $0.8 \mathrm{ml}$ subsample slurry was then placed using a volumetric pipette onto clear coverglass and left to dry for 24 hours. The coverglass subsamples were mounted to glass slides using Naphrax ${ }^{\circledR}$ (Brunel Microscopes, UK), a permanent adhesive with a refractive index of 1.73 .

An age-depth model was generated for both cores based on radiocarbon dates obtained from bulk sediments at eight horizons throughout the $131 \mathrm{~cm}$ long PKT_2FR1 core(Fig. 3.2; Table 1; Patterson et al., 2017). Two of these horizons were located immediately above and below the interval of interest $(57 \mathrm{~cm}$ and $52 \mathrm{~cm}$ ). Dates from these locations along with the previously 
documented time of deposition for the WRAe allowed for a highly accurate age-depth model throughout the study interval $(56.4-54.5 \mathrm{~cm})$. Samples were pretreated with $\mathrm{HCl}$ to remove carbonates. Radiocarbon dates were obtained using the accelerator mass spectrometer at the 14CHRONO Dating Laboratory in Belfast, United Kingdom. AMS radiocarbon dates were calibrated with OxCal v4.2 (Bronk Ramsey, 2009) and the IntCal13 calibration curve (Reimer et al., 2013). Age-depth relationships for the cores were developed using Bacon 2.2 (Blaauw and Chisten, 2011; 2013) applying accumulation rate and memory parameter values based on lakes in the central NWT (Crann et al., 2015).

Diatom counts were made using an Olympus BX51 light microscope at 1000x under oil immersion with a minimum of 600 valves enumerated per sample. Counts were collected from 20 samples at 1-mm intervals between 54.5 and $56.4 \mathrm{~cm}$ depth. Diatom taxa were identified at the lowest possible taxonomic level with reference to photomicrographs of taxa from similar geographic regions and environmental conditions (Krammer and Lange-Bertalot, 1985-1991; Hartley, 1996). Species names were corrected to current taxonomic nomenclature following Algaebase (Guiry and Guiry, 2018). Diatom counts were expressed in relative abundance and plotted stratigraphically using C2 version 1.7 (Juggins, 2014).

Significant taxa were identified using the methodology outlined in Patterson and Fishbien (1989). Only taxa present in significant numbers in at least one sample throughout the interval were included in subsequent analyses. To determine this, the standard error was calculated for the individual taxon in each subsample. If this value exceeded the abundance of a taxon, it was deemed insignificant in that sample (Patterson and Fishbien, 1989). Of the 79 taxa identified throughout the interval only 38 were found to be significant enough to be included. Non-metric multidimensional Scaling (NMDS) analysis was used to ordinate samples based on similar diatom 
taxa to visualize changes at the assemblage scale ( $\mathrm{n}=20$ samples). NMDS allowed visually grouping of samples containing similar assemblages as well as the taxa that defined each group. It was chosen over other multivariant ordination techniques because it allowed for samples to be assessed based solely on similarities in assemblage structure without assuming any underlying variable-environmental gradient relationships (Paliy and Shankar, 2016). In addition, Stratigraphically Constrained Incremental Sum of Squares (CONISS) cluster analysis was conducted using the rioja package in RStudio to identify stratigraphic zones based on changes in the diatom community composition. Visual inspection coupled with the results provided via CONISS and NMDS were used to define stratigraphic zones based on diatom assemblages. 


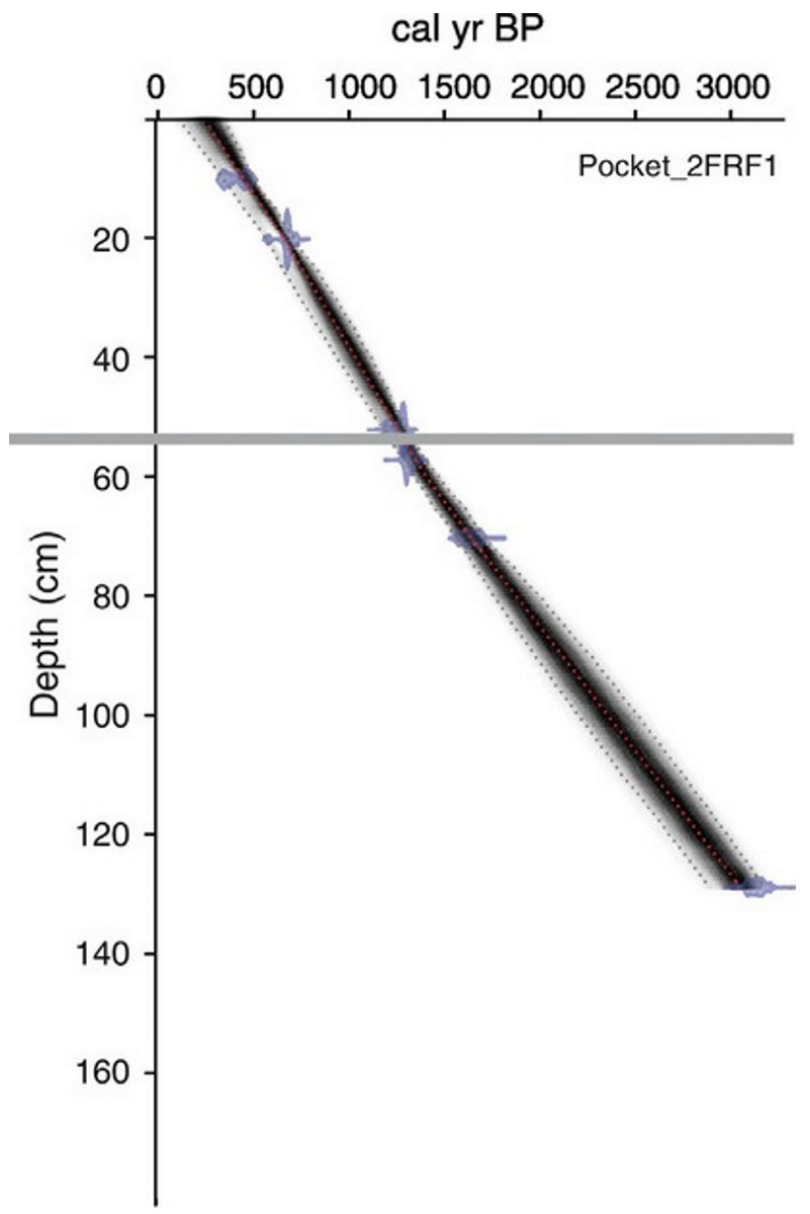

Figure 3.2 Age-depth model produced for PKT_2FR1.The grey line delineates the depth of the WRAe (1,110 \pm 50 cal BP). Redrafted after Patterson et al. (2017).

\begin{tabular}{|c|c|c|c|c|c|}
\hline & Lab ID & $\begin{array}{l}\text { Depth } \\
\text { (cm) }\end{array}$ & $\begin{array}{l}14 C \text { age } B P \pm \\
1 \sigma\end{array}$ & Pretreatment & Cal BP $\pm 2 \sigma$ \\
\hline & UBA- & & & & \\
\hline \multirow{12}{*}{ PKT_2FR1 } & 20676 & $10-10.5$ & $362 \pm 27$ & Acid Only & 500-422 (50.7\%) \\
\hline & & & & & 400-316 (44.7\%) \\
\hline & UBA- & & & & \\
\hline & 22350 & $20-20.5$ & $731 \pm 31$ & Acid Only & 727-653 (95.4\%) \\
\hline & UBA- & & & & \\
\hline & 20679 & $52-52.5$ & $1335 \pm 25$ & Acid Only & 1302-1239 (85.5\%) \\
\hline & & & & & 1205-1186 (9.9\%) \\
\hline & Tephra & $55.4-55.7$ & & & $1110 \pm 50$ \\
\hline & UBA- & & & & \\
\hline & 22351 & $57-57.5$ & $1394 \pm 30$ & Acid Only & 1350-1279 (95.4\%) \\
\hline & UBA- & & & & \\
\hline & 22352 & $70-70.5$ & $1725 \pm 31$ & Acid Only & 1707-1561 (95.4\%) \\
\hline
\end{tabular}


UBA-

20678

$128.5-129 \quad 2966 \pm 26$

Acid Only

3215-3057 (93.9\%)

Table 3.1 Radiocarbon dates from PKT_2FR1. Dates were calibrated with the intCal13

calibration curve (Reimer et al., 2013) using OxCal v4.2.4 following the methods given in Millard (2014). The tephra date is based on wiggle-match date for the WRAe (Jensen et al., 2014). Redrafted after Patterson et al. (2017).

\subsection{Results}

The tephra in core PKT_2FR1 appeared as a 3-5 mm white band composed of clear, glassy shards at 55.4-55.7 cm depth (Patterson et al., 2017; Fig. 3.3). Based on the age-depth model generated for this core, the core captured sediments as old as 3215-3057 cal yr BP. The WRAe horizon, deposited 1117-1100 cal BP, occurred at $55.4 \mathrm{~cm}$ depth, with a modelled sedimentation rate of 2 $\mathrm{yrs} / \mathrm{mm}$ (Patterson et al., 2017). Due to the timing and nature of the Mount Churchill eruption, the addition of the tephra would have led to the amount of material deposited that year being much greater than normal. Consequently, the four samples containing the ash layer $(55.4-55.7 \mathrm{~cm})$ collectively represented a single season of deposition (1 year). The well-defined age of the tephra layer as well as the two radiocarbon dates obtained above and below the interval of interest (52 and $57 \mathrm{~cm}$ depth; Fig. 3.2; Table 1) allowed for a high degree of confidence in the calculated time represented in each sample.

Seventy-nine diatom taxa were identified in the 20 samples examined through the $2 \mathrm{~cm}$ studied interval, which included the WRAe tephra, and were dominated by benthic taxa. Planktic (centric) diatoms such as Discostella pseudostelligera, Cyclotella distinguenda, and Lindavia michiganiana were recorded, but together never exceeded $10 \%$ relative abundance. Above 55.9 
$\mathrm{cm}$, small centric taxa consistently decreased in relative abundance, almost disappearing above $54.8 \mathrm{~cm}$ depth.

Based on the interpretations generated via CONISS and NMDS, three distinct diatom assemblages were identified in the $2 \mathrm{~cm}$ interval of the core: 1) the "Pre-WRAe Assemblage (PreWRAeA)" (56.4-55.7 cm); 2) the "WRAe Assemblage (WRAeA)" (55.6-55.4 cm); and the 3) the overlying "Post-WRAe Assemblage (Post-WRAeA)" (55.3-54.5 cm). Plotted changes in relative abundances of diatom taxa for the interval are used to illustrate these stratigraphic and temporal trends (Fig. 3.4).

The lowermost Pre-WRAeA is indicative of acidic and eutrophic conditions. In the PreWRAeA ( 56.4 to $55.9 \mathrm{~cm}, n=6$ ), Nitzschia palea (sensu lato) was the most common single species with a median abundance of $21.0 \%$ (min: $18.7 \%$, max: $25.3 \%$ ). Navicula species had a median abundance of $23.0 \%$ (min: $19.6 \%$, max: $27.2 \%$ ); the most common species were Navicula schweigeri (2.8\%), Navicula notha (4.9\%) and Navicula cryptotenella (7.2\%). Important taxa of lesser abundance throughout this interval were Brachysira microcephala (12.6\%), Encyonopsis microcephala (8.5\%), Discostella pseudostelligera (2.5\%), Achnanthidium atomus (4.8\%), and Achnanthidium minutissimum (1.8\%; Fig. 3.4). No significant trends were observed in the assemblage present throughout this interval.

A shift to the WRAeA occurred immediately following the deposition event (55.6 to 55.4 $\mathrm{cm}$ inclusive; $\mathrm{n}=3$ ). This interval contains material collectively representing one year of deposition. Although the $55.7 \mathrm{~cm}$ sample contained the tephra contact, the WRAeA was not observed. This could potentially be do to contamination from the underlying lake sediment causing the shift to be obscured. Again, this assemblage was dominated by N. palea (19.6\%) and Navicula spp. (23.1\%). The less abundant Navicula wildii was elevated in relative abundance between 55.6 
and $55.4 \mathrm{~cm}$ depth, increasing from a median of $1.1 \%$ to $2.4 \%$ with a peak of $3.7 \%(55.4 \mathrm{~cm})$. This increase was not observed in other Navicula species. A decrease in relative abundance was recorded for B. microcephala, E. microcephala as well as A. atomus and A. minutissimum for the same interval (Fig. 3.4). The relative abundance of centric diatom L. michiganiana was elevated throughout the tephra interval peaking twice at 55.6 and $55.4 \mathrm{~cm}$ depth, then followed by a sharp decline. Minor constituents of the WRAeA showed greater variability than the primary taxa. The relative abundance of Denticula elegans increased from a median value of $\sim 0.3 \%$ before the tephra to a maximum of $2.1 \%$ in this interval. Slight increases in relative abundances were also recorded for N. amphibia and Pseudostaurosira brevistriata. Conversely, a decrease in abundance was recorded for Encyonema minutum and Hantzschia amphioxys, Encyonema hebridicum, $N$. schweigeri and $N$. ampliatum.

Above 55.4 the Post-WRAeA is observed. The Post-WRAeA is initially similar to the PreWRAeA but becomes more unique upwards. Between $55.1 \mathrm{~cm}$ and $54.5 \mathrm{~cm}$, the relative abundance of centric diatoms consistently decreased from $6.1 \%$ to $2.6 \%$. Nitzschia palea initially decreased from $17.3 \%$ to $12.3 \%$ between $55.2 \mathrm{~cm}$ and $54.7 \mathrm{~cm}$ but subsequently recovered to a relative abundance of $18.6 \%$. The opposite pattern was observed in N. cryptotenella, which increased in abundance over the same interval from $6.3 \%$ to $11.3 \%$. Again, this was followed by a decline to 8.0\%. Similar patterns are observed in the abundance of B. microcephala and S. pupula. For each taxa, a gradual increase is observed from $\sim 55.2 \mathrm{~cm}$ to $\sim 54.7 \mathrm{~cm}$, increasing from $15.7 \%$ to $21.5 \%$ and 2.9 to 6.9 respectively. 

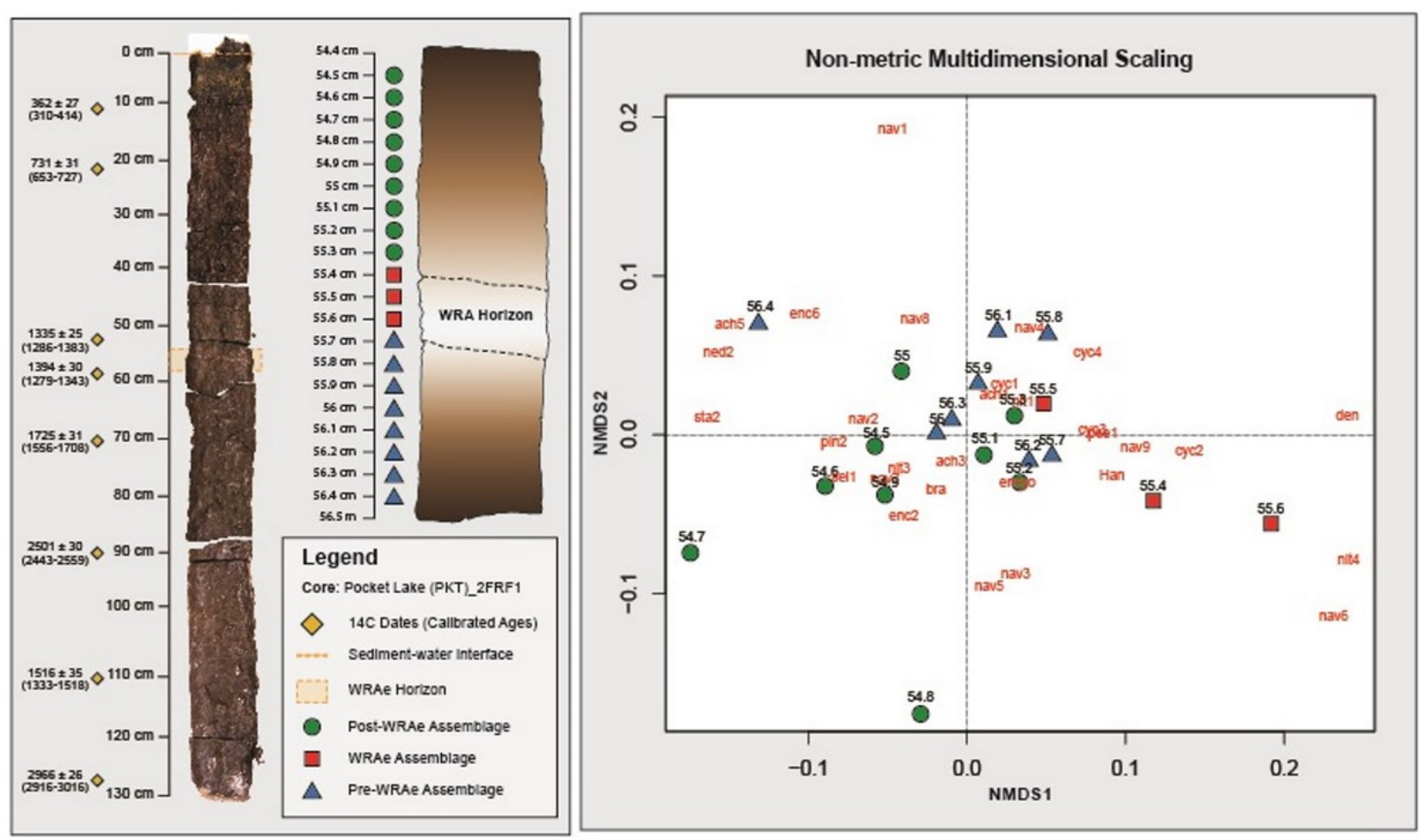

Figure 3.3 Non-metric Multidimensional Scaling analysis.

Samples containing a similar diatom composition are grouped. Grouping is observed between the Pre-WRAe Assemblage (green), the WRAe Associated Assemblage (red), and the Post-WRAe Assemblage (blue). Stratigraphic location of each sample in the core is indicated on the left panel and the radiocarbon dates used to develop the age-depth model are plotted beside the photographed core. Dotted lines illustrate the top and bottom of the WRAe horizon. The first three letters of each taxon represents the genus name and each numeric value indicates a unique species within the genera. Where only the genus name is given, only one member was recorded. Nav, Navicula; Ency, Encyonema; Sell, Sellaphora; Pseud, Pseudostaurosira; Psam, Psamnothidium; Cyc, Cyclotella sensu lato; Den, Denticula; Bra, Brachysira; Ach, Achnanthidium; Ned, Neidium; Cym, 
Cymbopleura; Staur, Stauroneis; Pinn, Pinnularia; Han, Hantzschia.

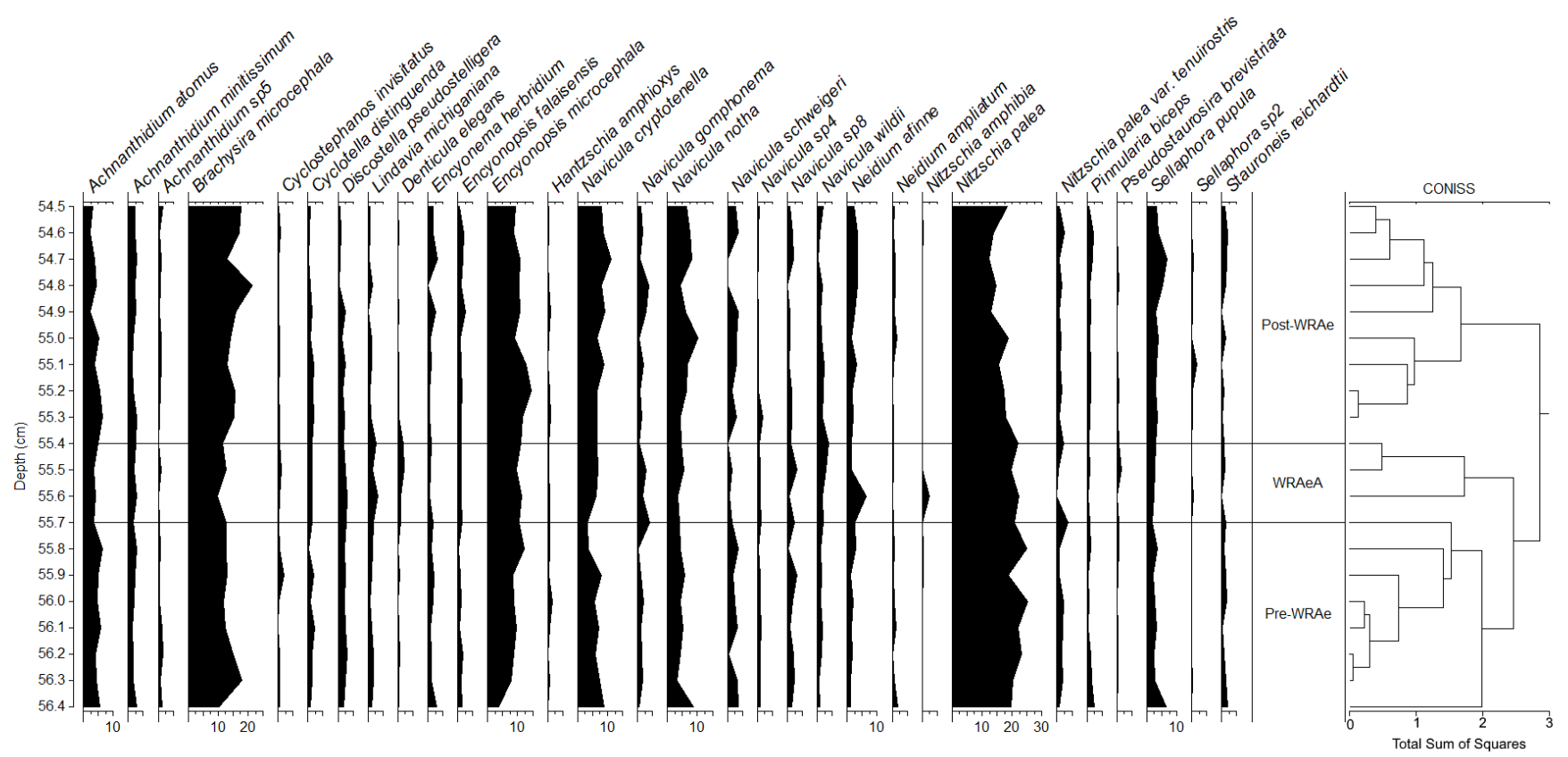

Figure 3.4: Relative abundance profiles of diatom taxa from Pocket Lake (PKT_2FR1).

Taxa are grouped based on morphology. Only taxa deemed statistically significant in at least one sample are included.

\subsection{Discussion}

The samples throughout the $54.5-56.4 \mathrm{~cm}$ depth interval were consistently dominated by benthic diatom taxa. Pocket Lake is $6 \mathrm{~m}$ deep at its $-Z_{\max }$ and has a surface area of 4 ha (Spence, 2000; Reid, 1997). The high proportion of benthic taxa may be related to the northern location and shallow depth of Pocket Lake. Shallower lakes allow more light penetration to the bottom of the lake resulting in the success of benthic taxa. Long periods of seasonal ice cover present in lakes in cold, northern climates limit light penetration, nutrient supply and the planktic zone for a 
significant part of the year leading to a diatom composition dominated by tychoplanktic and benthic taxa that are competitive in the moat surrounding retreating ice in spring (Smol, 1988).

Three distinct diatom assemblages characterized the $2 \mathrm{~cm}$ interval of the core: the lowermost Pre-WRAeA, the overlying WRAeA and the uppermost Post-WRAeA characterized by a partial return to pre-WRAe conditions. The lowermost Pre-WRAeA $(56.4-55.7 \mathrm{~cm})$ is indicative of slightly acidic and eutrophic conditions. Navicula palea and B. microcephala are tolerant of both acidic conditions and nutrient enrichment (Lange-Bertalot, 1979; Hamilton et al., 2015). The most common Navicula species in the Pocket Lake core are $N$. schweigeri and $N$. cryptotenella, which are moderately tolerant to pollution and are often associated with waters rich in organic material (Lange-Bertalot, 1979). Results from NMDS analysis show overlap between the upper samples of the Pre-WRAeA and the lowermost samples of the Post-WRAeA. This potentially indicates that the changes this assemblage change was likely primarily derived from broad regional environmental trends independent from the Mount Churchill eruption. That is, the WRAe deposition was only a driving force in the first assemblage change, to the WRAeA and not the second shift. Hydrologic changes in Pocket Lake resulting from the WRAe were only sustained for the growing season immediately following the Mount Churchill event. Changes observed in the samples following the WRAe interval were therefore largely due to other broader environmental changes and not the Mount Churchill event. Taxa that dominated the Pre-WRAeA (e.g. N. palea and various Navicula spp) continued to be the most common taxa in the PostWRAeA. However, gradual changes in the relative abundances of several other taxa (e.g. $B$. microcephala, several Navicula species, S. reichardtii, N. ampliatum) continued stratigraphically upwards through samples comprising the Post-WRAeA. Higher abundances of small planktic centric diatoms is often associated with warmer climates. Their observed decline in the Post- 
WRAeA potentially indicates that the region experienced a cooling climate (Lotter et al., 1998; Winder et al., 2009; Saros and Anderson, 2015).

The WRAeA (55.6-55.4 cm), which developed immediately after WRAe deposition, was characterized by a higher relative abundance of taxa associated with decreased productivity and more alkaline waters. This is most apparent in the relative abundances of Navicula wildii (1.2\% to a peak of $3.7 \%)$, Lindavia michiganiana (1.2\% to a peak of 3.5\%), Pseudostaurosira brevistriata $(\sim 0.3 \%$ to a peak of $0.8 \%)$ and Denticula elegans $(<1 \%$ to a peak of $2.1 \%)$. These species indicate a slight shift away from the moderately eutrophic conditions inferred for Pocket Lake prior to deposition of the ash (Lange-Bertalot, 2001; Le Blanc et al., 2004). Increases in the abundance of D. elegans suggest greater sedimentation rates as the ash eroded into the lake from the catchment (Le Blanc et al. 2004). Tephra material added to a shallow lake like Pocket Lake may have led to increased turbidity that limited light penetration (Hickman and Reasoner, 1994). Additionally, tephra material covering the lakebed may have inhibited nutrient diffusion from the normal lake sediments into the overlying water column causing depletion in dissolved concentrations of certain nutrients (Hickman and Reasoner, 1998). Both mechanisms may have collectively reduced the overall productivity in the lake leading to the increase in oligotrophic taxa and reduction of taxa tolerant of eutrophic, and acidic, conditions. The relative abundance of several Achnanthidium species, particularly A. minutissimum, along with B. microcephala, decreased coincident within the tephra containing interval. Competition from other species favoured by the moderate changes in water chemistry might also be a contributing factor to the decrease in relative abundance for these (Lotter et al., 1998). However, in the Lotter et al. (1998) study, dissolution of tephra shards did not influence observed changes in diatom composition. Geochemical analysis of the tephra shards by Patterson et al. (2017), found them to be primarily rhyodacitic, with the dissolution rate 
being closely tied to the silica content present in the shard. Experimental studies have found that such silica-rich material will still require thousands of years to dissolve, even under slightly acidic conditions, and would thus not impact the water chemistry of the lake (Wolff-Boenisch et al., 2004a; 2004b). Other research has found that bacterial communities in natural water bodies can mediate the dissolution process of silica-rich tephra, substantially increasing the rate of dissolution but still not to the degree required to alter the water chemistry of Pocket Lake within the short time interval where changes in diatom composition are observed (Thorseth et al., 1995; Staudigel et al., 1998; Brehm et al. 2004).

The observed diatom assemblage response to the WRAe deposition was most apparent in samples containing tephra material, indicating that major changes in water property characteristics were only sustained during one season of deposition. The winter eruption of Mount Churchill resulted in the bulk of the volcanic ash falling out onto snow cover, which entered Pocket Lake the following spring carried in snow melt runoff from the catchment (Robinson, 2001; Lerbekmo, 2008; Patterson et al., 2017). Therefore, the samples containing the WRAe $(55.4-55.7 \mathrm{~cm}$ inclusive; $n=4$ ) material likely represent the same year. Results from both CONISS and NMDS indicated a shift to a new assemblage in samples contained within this interval. The samples above the interval form a third distinct group indicating the WRAe was not a significant factor controlling diatom assemblage beyond the year in which it was deposited. Although results from both CONISS and NMDS support the assemblages above and below the WRAe interval being distinct groups, plotted results from NMDS analysis show some overlap between them. Overlap between these two groups indicates that the diatom composition present in each was very similar. This shift back to an assemblage similar A shift back to an assemblage close in structure to the one preceding the 
WRAe suggests that at least a partial return to pre- WRAe conditions occurred the following year with the tephra no longer having a significant influence on hydrologic conditions within the lake.

Similar changes have been observed in several previous studies (e.g. Lotter and Birks (1993), 10 mm thick layer in two ancient lake beds; Birks and Lotter (1994), 78-mm thick layer, Holzmaar, Germany; Jovanovska et al. (2016), $15 \mathrm{~cm}$ thick in cores from Lakes Ohrid and Prespa). Other studies have reported no clear relationship between tephra layer thickness and impact on the diatom community (e.g. Hickman and Reasoner, 1994; 1998, in studies on $=\sim 10 \mathrm{~cm}$ thick and $\sim 5$ $\mathrm{cm}$ thick tephra layers). As discussed below sampling resolution may have influenced the ability to detect temporary ecological responses to tephra deposition.

The recovery rate of diatom populations reported in previous studies of lakes impacted by ash falls, and where the ash has impacted lake ecology, varies substantially. For example, one study documented gradual recovery of diatom populations over hundreds of years (Hickman and Reasoner, 1994), another reported a much shorter, 2-20-year recovery period (Hickman and Reasoner, 1998), and in Germany short-lived impacts of tephra deposition on lacustrine diatom communities ranging from $\sim 5-20$ years were observed in the Black Forest region (Lotter and Birks, 1993). In other examples, Hickman and Reasoner $(1994,1998)$ assessed the impact of tephra units on the diatom flora in alpine lakes from Yoho and Banff national parks, Alberta, Canada, and found little change in the composition of the diatom community following tephra deposition aside from a slight increase in diversity. Similar to the transition from the Pre-WRAeA to the PostWRAeA, Hickman and Reasoner (1998) attributed their observed changes in the relative abundance of diatoms to coeval changes in other environmental variables (e.g. precipitation, temperature, changes in vegetation) unrelated to tephra deposition. 
Based on the varying responses of diatom assemblages to tephra deposition described above it is obvious that a variety of environmental factors influence diatom ecological responses to tephra deposition including lake morphology, water chemistry, lake sedimentology and the volume and thickness of tephra deposited (Lotter and Birks, 1993; Telford et al., 2004). In deeper lakes with established populations of planktic diatoms, the deposition of an ash layer appears to primarily impact benthic diatoms, leading to an increase in the relative abundance of planktic taxa (Lotter and Birks, 1993; Jovanovska et al., 2016). In shallow lakes, or lakes in regions with long periods of ice cover, a significant population of planktic diatoms cannot develop, and this pattern will not be observed (Wetzel, 1983; Rühland and Smol, 2005). Although many studies reported some response to the deposition of tephra, the significance of the relationship isn't clear. Lotter and Birks (1993) used partial RDA analysis to determine differences in the response of diatoms to the Laacher See Tephra in two different sampling sites in the Black Forest, Southern Germany. They found that in their cases the tephra as well as the lake sedimentology contributed to the variance that was observed, but it was unclear which was most important as both variables interacted with each other. Observed changes in sedimentology could have resulted from the deposition of the tephra but may also be explained by unrelated phenomena.

Observation of the brief temporal response and subsequent rapid recovery of the diatom community to deposition of the WRAe in Pocket Lake may in part be a result of the high resolution of sub-sampling carried out in this study, which contrasts with the coarser temporal resolution analyses carried out on similar lakes where no diatom response to tephra deposition was recorded (Hickman and Reasoner, 1994; 1998). It's possible that the coarse sample resulted in the diatom tephra response to obscured and therefore not observed. In Pocket Lake, major changes in the proportion of different taxa only persisted for approximately one year. The importance of carrying 
out high-resolution sub-sampling of cores to test diatom ecological response may also be evident in the Lotter and Birks (1993) study on the impact of the Lascher See Tephra in Holzmaar, Germany. There the impact of the tephra deposition on the environment was also short lived, with recovery occurring in 10-20 years, but due to the sampling resolution employed these changes could only be observed at decadal resolution (Lotter and Birks, 1993).

\subsection{Conclusions}

The results of this assessment of the ecological impact of WRAe tephra deposition in Pocket Lake show that there were short-duration changes in diatom flora. NMDS coupled with CONISS analysis reveal three distinct assemblages throughout the $2.0 \mathrm{~cm}$ interval, which included a $3-5$ mm thick tephra layer; the "Pre-WRAe Assemblage (Pre-WRAeA)", the "WRAe Assemblage (WRAeA)", and the "Post-WRAe Assemblage (Post-WRAeA)". In the basal Pre-WRAeA, the observed taxa are indicative of slightly acidic and eutrophic lake conditions. The WRAeA is associated with deposition of the WRAe, and is characterized by taxa associated with nutrient depletion and oligotrophic and mildly alkaline conditions. The WRAeA also suggests a change in lake conditions associated with deposition of the volcanic ash that resulted in a decrease in overall productivity, reduced water clarity and a slow down in nutrient exchange with lake bottom sediments. This shift was only sustained for a single year following ash deposition, after which the lake diatom community partially recovered. Immediately above the WRAe interval, a shift to the Post-WRAeA occurs. This assemblage is initially similar in structure to the Pre-WRAeA but moving up within the interval, this assemblage becomes gradually more unique showing an increase in taxa associated with decreased acidity and a colder climate. These trends are likely 
driven by changes in water quality associated with broader regional climatic trends. These results suggest that diatom communities in Pocket Lake were sensitive to deposition of the WRAe, but once the tephra was no longer being eroded from the watershed, and the hydrology of the lake was able to partially recover to its initial conditions; the diatoms community rapidly recovered and sustained no long-term impact related to the WRAe depositional event. This was in part due to the very slow dissolution of the rhyodacitic tephra, which was therefore essentially inert once deposited on the lake bottom. Due to the short-lived nature of the ecological shift, a mm-scale high-resolution subsampling strategy was necessary in order for the changes in the diatom assemblage to be recognized. In previous lakes studies where little to no response to an ash fall was observed, it is possible that similar short-lived changes in composition occurred but were not observed because the sub-sampling approach employed was too coarse. These findings emphasize the necessity of high-resolution sub-sampling strategies for paleolimnological studies attempting to recognize changes that might be relatively short lived or those that result from rare, instantaneous events. 


\subsection{Conclusion}

The primary objective of this research was to reconstruct historical changes in the lacustrine environment of Pocket Lake based on changes in diatom assemblage with reference to geochemical and particle size datasets as well as previous paleoclimatic reconstructions for the region. This study is notable due to the detailed high-resolution subsampling enabled using a freeze corer and a custom sledge microtome. Two different resolutions were employed with the purpose of investigating both the impact of broader climatic trends as well as the response to an instantaneous volcanic event.

In chapter 2 , changes were evident in diatom assemblages over the past $\sim 2800$ years of the latest Holocene at a resolution of $\sim 20-30$ years. The resulting dataset was then integrated with geochemical and grainsize datasets to investigate any potential relationship between diatom assemblage and these parameters. Analysis of temporal variation in these datasets with reference to previous paleoclimatic reconstructions for the region indicated that conditions within Pocket Lake were sensitive to past climate change. Water quality was found to vary substantially throughout the core. In the oldest section of the core, the diatom assemblage was rich in species favouring cold, alkaline waters, most notably Staurosira venter, which was the most common single species in the most basal section but virtually disappeared by 2240 cal yr BP. Cold, alkaline conditions were also supported by low abundances of warm water taxa and a strong association between the diatom assemblage present and calcium concentration. This is a stark contrast to more recent conditions. The diatom population present from between $1070-815 \mathrm{cal} \mathrm{yr}$ BP show elevated abundances of warm water species such as Sellaphora pupula as well acidophile species such as Brachysira microcephala. The timing of this assemblage overlaps with the Medieval Warm Period (1000-700 cal yr BP; Upiter et al., 2014) indicating that the 
increase in these species could be driven by warming climatic conditions. Another notable phenomenon was the substantial increase in Cyclotella species sensu lato, particularly Discotella stelligera. An elevated abundance of Cyclotella species is often associated with warmer conditions, however, the timing of their increase coincides with the Little Ice Age (500-250 cal yr BP; Mann et al., 2009), where colder, drier conditions prevailed. Although the specific driver of this trend is not clear, this observation highlights both the sensitivity of lakes in high-latitude locations to climate change as well as the complexity of their response.

The diatom response to the deposition of airfall tephra associated with White River Ash Eastern Lobe (WRAe), originating from the eruption of Mt. Churchill $\sim 117-1100 \mathrm{cal}$ BP is presented in chapter 3 . In contrast to the broader decadal climate phenomena investigated in Chapter 2, the deposition of the WRAe likely occurred as an instantaneous event. Most prior research into the diatom response to similar events involved layers of tephra at least an order of magnitude thicker and at a much coarser resolution than what was used here. However, due to the instantaneous nature of the event and the small amount of material deposited, the influence of this event was likely short lived and would be obscured if the subsampling resolution was not sufficiently fine. The use of a freeze corer and custom sledge microtome allowed for an unprecedented resolution of $\sim 1.5$ years per sample allowing for insight into the response in the years immediately following the WRAe event. Visual analysis of the results generated via Nonmetric Multidimensional Scaling (NMDS) and Stratigraphically Constrained Incremental Sum of Squares (CONISS) revealed a significant change in assemblage coincident with the tephra layer, unique from the assemblages above and below it. This assemblage was enriched in diatom taxa associated with oligotrophic, nutrient depleted, and slightly more alkaline waters. It was only documented in the samples containing tephra material indicating that the changes resulting from 
the WRAe deposition event were short-lived with the lake recovering by the following spring. These results suggest that that lacustrine environments are sensitive to instantaneous events, such as the deposition of airfall tephra, but are also resilient and can rapidly recover. If a more standard subsampling resolution had been used, these changes would not have been observed. These finding emphasize the importance of high-resolution subsampling when investigating the impact of geologically near instantaneous events, such as the episodic deposition of airfall tephra.

The results of these two studies showcase the sensitivity of lakes in these highly sensitive locations to both long-term climate change and instantaneous events (natural and anthropogenic). Climate change in the $21^{\text {st }}$ century has the potential to radically alter environmental conditions, particularly those of high-latitude locations. In order to accurately predict the impact of future climate change and episodic events such as volcanic ashfall, knowledge of prior events is required. This research provides insight into the impact of climate events throughout the latest Holocene on lacustrine environments which will help develop a more comprehensive understanding of how these environments might be impacted by climate change in the $21^{\text {st }}$ century. 


\subsection{References}

Abella S. 1988. The effect of the Mt. Mazama ashfall on the planktonic diatom community of Lake Washington. Paleoecology, 33(4), 1376-1385.

ACIA, 2004. Impacts of a Warming Arctic: Arctic Climate Impact Assessment. Cambridge, UK.

Barker P, Williamson D, Gasse F, Gibert E. 2003. Climatic and volcanic forcing revealed in a 50,000-year diatom record from Lake Massoko, Tanzania. Quaternary Research, 60(3), 368376. http://doi.org/10.1016/j.yqres.2003.07.001

Battarbee RW. 1984. Diatom analysis and the acidification of Lakes. Philosophical Transactions of the Royal Society of London. B305, 451-477

Battarbee RW. 2000. Palaeolimnological approaches to climate change, with special regard to the biological record. Quaternary Science Reviews, 19(1-5), 107-124. https://doi.org/10.1016/S0277-3791(99)00057-8

Blaauw M, Christen JA. 2011. Flexible paleoclimate age-depth models using an autoregressive gamma process. Bayesian Analysis. 6, 457-474.

Blaauw M, Christen JA. 2013. Bacon Manual. Available at. http://chrono.qub.ac.uk/ blaauw/manualBacon_2.2.pdf.

Birks HJB, Lotter AF. 1994. The impact of the Laacher See Volcano (11000 yr BP) on terrestrial vegetation and diatoms. Journal of Paleolimnology 11: 313-322.

Bouchard G, Gajewski K, Hamilton PB. 2004. Freshwater diatom biogeography in the Canadian Arctic Archipelago. Journal of Biogeography, 31(12), 1955-1973.

https://doi.org/10.1111/j.1365-2699.2004.01143.x 
Bourgeois JC, Koerner RM, Gajewski K, \& Fisher DA. 2000. A Holocene Ice-Core Pollen

Record from Ellesmere Island, Nunavut, Canada. Quaternary Research, 54(2), 275-283. https://doi.org/10.1006/qres.2000.2156

Boyle JF. 2001. Inorganic geochemical methods in palaeolimnology. In: Last, W.M., Smol, J.P. (Eds.), Tracking Environmental Change Using Lake Sediments. Volume 2: Physical and Geochemical Methods. Kluwer Academic Publishers, Dordrecht, pp. 83-142 https://doi.org/10.1007/0-306-47670-3_5.

Boyle RW. 1960. The Geology, Geochemistry and Origin of Gold Deposits of the Yellowknife District; Geological Survey of Canada Memoir 310. Department of Mines and Technical Surveys Canada, Ottawa, Ontario, 193

Brahney J, Clague JJ, Menounos B, Edwards TWD. 2007. Geochemical reconstruction of late Holocene drainage and mixing in Kluane Lake, Yukon Territory. Journal of Paleolimnology, 40(1), 489-505. https://doi.org/10.1007/s10933-007-9177-z

Brehm U, Gorbushima A, Mottershead D. 2004. The role of microorganisms and biofilms in the breakdown and dissolution of quartz and glass. Palaeogeography, Palaeoclimatology, Palaeoecology, 219, 117-129.

Brett MT, Muller-Navarra DC. 1997. The role of highly unsaturated fatty acids in aquatic food web processes. Freshwater Biology. 38, 483-499. (doi:10.1046/j.1365-2427. 1997.00220.x) Bronk-Ramsey C. 2009. Bayesian analysis of radiocarbon dates. Radiocarbon, 51, 337-360. Bullen WD, \& Robb ME. 2004. Socioeconomic Contribution of Gold Mining in the Yellowknife Mining District, 1-9. Retrieved from file://C:/Users/Cloudy Dydy/Google Drive/Robb-BullenSocio-Economic Impacts of Gold Mining in Yellowknife2004.pdf 
Callaghan TV, Jonasson C, Thierfelder T, Yang Z, Hedena H, Johansson M, Molau U, Van Bogaert R, Michelsen A, Olofsson J, Gwynn-Jones D, Bokhorst S, Phoenix G, Bjerke JW, Tømmervik H, Christensen TR, Hanna E, Koller EK, Sloan VL. 2013. Ecosystem change and stability over multiple decades in the Swedish subarctic: complex processes and multiple drivers. Philosophical Transactions of the Royal Society B: Biological Sciences, 368(1624), 2012048820120488. https://doi.org/10.1098/rstb.2012.0488

Crann CA, Patterson RT, Macumber AL, Galloway JM, Roe HM, Blaauw M, Falck H. 2015. Sediment accumulation rates in subarctic lakes: insights from 22 dated lake re-cords and applications with age-depth modeling. Quaternary Geochronology. 27, 131-144

Cruces F, Urrutia R, Parra O, Araneda A, Treutler H, Bertrand S, Fagel N, Torres L, Barra R, Chirinos L. 2006. Changes in diatom assemblages in an Andean lake in response to a recent volcanic event. Archiv Für Hydrobiologie, 165(1), 23-35. http://doi.org/10.1127/0003-

\section{6/2006/0165-0023}

Cousens BL. 2000. Geochemistry of the Archean Kam Group, Yellowknife greenstone belt, Slave Province, Canada. Journal of Geology. 108, 181-197.

Cousens BL, Facey K, Falck H. 2002. Geochemistry of the late Archean Banting Group, Yellowknife greenstone belt, Slave Province, Canada: simultaneous melting of the upper mantle and juvenile mafic crust. Canadian Journal of Earth Science. 39, 1635-1656.

Dalton AS, Patterson TR, Roe HM, Macumber AL, Swindles GT, Galloway JM, Swindles GT, Vermaire JC, Falck H. 2018. Late Holocene climatic variability in Subarctic Canada: Insights from a high-resolution lake record from the central Northwest Territories. PLoS ONE, 13(6), 121. https://doi.org/10.1371/journal.pone.0199872 
Delworth TL, Zeng F, Vecchi GA, Yang X, Zhang L, Zhang R. 2016. The North Atlantic Oscillation as a driver of rapid climate change in the Northern Hemisphere. Nature Geoscience, 9(7), 509-512. https://doi.org/10.1038/ngeo2738

Deser C, Alexander MA, Xie S-P, Phillips AS. Sea Surface Temperature Variability: Patterns and Mechanisms. Annual Review of Marine Science. 2010; 2:115-43.

https://doi.org/10.1146/annurev-marine- 120408-151453 PMID: 2114166014.

Dietze E, Maussion F, Ahlborn M, Diekmann B, Hartmann K, Henkel K, Kasper T, Lockot G, Opitz S, Haberzettl T. 2014. Sediment transport processes across the Tibetan Plateau inferred from robust grain-size end members in lake sediments. Climate of the Past, 10(1), 91-106. https://doi.org/10.5194/cp-10-91-2014

Dietze E, Hartmann K, Diekmann B, IJmker J, Lehmkuhl F, Opitz S, Stauch G, Wünnemann B, Borchers A. 2012. An end-member algorithm for deciphering modern detrital processes from lake sediments of Lake Donggi Cona, NE Tibetan Plateau, China. Sedimentary Geology, 243244, 169-180. https://doi.org/10.1016/j.sedgeo.2011.09.014

Dietze M, Dietze E. 2016. EMMAgeo: End-Member Model- ling of Grain-Size Data. R package version 0.94. Available at: https://CRAN.R-project.org/package=EMMAgeo.

Dixit SS, Smol JP, Kingston JC, Charles DF. 1992. Diatoms: Powerful Indicators of Environmental Change. Environmental Science and Technology, 26(1), 22-33. https://doi.org/10.1021/es00025a002

Dixit AS, Alpay S, Dixit SS, Smol JP. 2007. Paleolimnological reconstructions of RouynNoranda lakes within the zone of influence of the Horne Smelter, Québec, Canada. Journal of Paleolimnology, 38(2), 209-226. https://doi.org/10.1007/s10933-006-9072-z 
Eastwood WJ, Tibby J, Roberts N, Birks HJB, Lamb HF. 2002. The environmental impact of the Minoan eruption of Santorini (Thera): statistical analysis of palaeoecological data from Gölhisar, southwest Turkey. The Holocene, 12(4), 431-444. http://doi.org/10.1191/0959683602h1557rp Fallu MA, Allaire N, Peinitz R. 2000. Freshwater diatoms from northern Québec and Labrador (Canada). Species-environment relationships in lakes of boreal forest, forest-tundra and tundra regions Bibliotheca Diatomologica 45: 1-200

Fawcett SE, Jamieson HE, Nordstrom DK, McCleskey RB. 2015. Arsenic and antimony geochemistry of mine wastes, associated waters and sediments at the Giant Mine, Yellowknife, Northwest Territories, Canada. Applied Geochemistry 62, 3-17. (doi:10.1016/j. apgeochem.2014.12.012)

Galloway JM, Macumber AL, Patterson RT, Falck H, Hadlari T, Madsen E. 2010. NWT Open Report 2010-002: Paleoclimatological Assessment of the Southern Northwest Territories and Implications for the Long-Term Viability of the Tibbitt to Contwoyto Winter Road, Part I : Core Collection, 002(August), 23.

Galloway JM, Swindles GT, Jamieson HE, Palmer M, Parsons MB, Sanei H, Macumber AL, Patterson TR, Falck H. 2018. Organic matter control on the distribution of arsenic in lake sediments impacted by $\sim 65$ years of gold ore processing in subarctic Canada. Science of the Total Environment, 622-623, 1668-1679. https://doi.org/10.1016/j.scitotenv.2017.10.048 Gajewski K, Garneau M, Bourgeois JC. 1995. Paleoenvironments of the Canadian high arctic derived from pollen and plant macrofossils: Problems and potentials. Quaternary Science Reviews, 14(6), 609-629. https://doi.org/10.1016/0277-3791(95)00015-H 
Gajewski K, Hamilton PB, McNeely R. 1997. A high-resolution proxy-climate record from an arctic lake with annually-laminated sediments on Devon Island, Nunavut, Canada. Journal of Paleolimnology, 17(2), 215-225. https://doi.org/10.1023/A:1007984617675

Gregory-Eaves I, Smol JP, Finney BP, Edwards ME. 1999. Diatom-based transfer functions for inferring past climatic and environmental changes in Alaska, U.S.A. Arctic Antarctic and Alpine Research. 31: 353-365.

Guiry MD, Guiry GM. 2018. AlgaeBase. World-wide electronic publication, National University of Ireland, Galway. http://www.algaebase.org; searched on 30 January 2018.

Gray LJ, Beer J, Geller M, Haigh JD, Lockwood M, Matthes K, Cubasch U, Fleitmann D, Harrison G, Hood L, Luterbacher J, Meehl GA, Shindell D, van Geel B, White W. 2010. Solar Influences on Climate. Reviews of Geophysics, 50(1). https://doi.org/10.1029/2011rg000387 Hamilton PB, Lavoie I, Alpay S, Ponader K. 2015. Using diatom assemblages and sulphur in sediments to uncover the effects of historical mining on Lake Arnoux (Quebec, Canada): A retrospective of economic benefits versus environmental debt. Frontiers in Ecology and Evolution, 3(September), 1-16. https://doi.org/10.3389/fevo.2015.00099

Hanson LW. 1965. Size distribution of the White River ash, Yukon Territory. M.Sc. thesis, University of Alberta, Edmonton, Alberta.

Hargrave BT. 1972. Aerobic Decomposition of Sediment and Detritus As a Function of Particle Area and Organic Content. Limnology and Oceanography, 17(July), 583-596.

https://doi.org/10.4319/10.1972.17.4.0583

Harper MA, Howorth R, McLeod M. 1986. Late Holocene diatoms in Lake Poukawa: Effects of airfall tephra and changes in depth. New Zealand Journal of Marine and Freshwater Research, 20(1), 107-118. http://doi.org/10.1080/00288330.1986.9516135 
Hartley B. 1996. An Atlas of British Diatoms. Biopress Limited.

Herndon EM, Havig JR, Singer DM, McCormick ML, Kump LR. 2018. Manganese and iron geochemistry in sediments underlying the redox-stratified Fayetteville Green Lake. Geochimica et Cosmochimica Acta, 231, 50-63. https://doi.org/10.1016/j.gca.2018.04.013

Hickman M, Reasoner MA. 1994. Diatom responses to late Quaternary vegetation and climate change, and to deposition of two tephras in an alpine and a sub-alpine lake in Yoho National Park, British Columbia. Journal of Paleolimnology, 11(2), 173-188.

http://doi.org/10.1007/BF00686864

Hickman M, Reasoner MA. 1998. Late quaternary diatom response to vegetation and climate change in a subalpine lake in Banff National Park, Alberta. Journal of Paleolimnology, 20(3), 253-265. http://doi.org/10.1023/A:1007978730349

Jensen BJL, Pyne-O’Donnell S, Plunkett G, Froese DG, Hughes PDM, Sigl M, Pilcher JR. 2014. Transatlantic distribution of the Alaskan White River Ash. Geology, 42(10), 875-878. https://doi.org/10.1130/G35945.1

Joynt III EH, Wolfe AP. 2001. Paleoenvironmental inference models from sediment diatom assemblages in Baffin Island lakes (Nunavut, Canada) and reconstruction of summer water temperature. Canadian Journal of Fisheries and Aquatic Sciences, 58(6), 1222-1243.

\section{https://doi.org/10.1139/f01-071}

Jovanovska E, Cvetkoska A, Hauffe T, Levkov Z, Wagner B, Sulpizio R, Franke A, Albrecht C, Wilke T. 2016. Differential resilience of ancient sister lakes Ohrid and Prespa to environmental disturbances during the Late Pleistocene. Biogeosciences, 13(4), 1149-1161.

http://doi.org/10.5194/bg-13-1149-2016 
Juggins S. 2014. C2 Version 1.7.6: Software for Ecological and Palaeoecological Data Analysis and Visualisation. Newcastle University.

Juggins S, Birks HJB. 2002. Tracking Environmental Change Using Lake Sediments (Vol. 3). https://doi.org/10.1007/0-306-47668-1

Karst-Riddoch TL, Pisaric MFJ, Smol JP. 2005. Diatom responses to 20th century climaterelated environmental changes in high-elevation mountain lakes of the northern Canadian Cordillera. Journal of Paleolimnology, 33(3), 265-282. https://doi.org/10.1007/s10933-004-

\section{$\underline{5334-9}$}

Kerr DE. 2006. Chapter 20: quaternary geology and exploration geochemistry. In: Anglin, C.D., Falck, H., Wright, D.F., Ambrose, E.J. (Eds.), GAC Special Publication No.3, Gold in the Yellowknife Greenstone Belt, Northwest Territories: Results of the Extech III Multidisciplinary Research Project. Pp. 301-324.

Kling H, Håkansson H. 1988. A light and electron microscope study of Cyclotella species (Bacillariophyceae) from central and northern Canadian lakes. Diatom Research 3, 55-82. Krammer K, Lange-Bertalot H. 1985-1991. Süßwasserflora von Mittleuropa, eds H. Ettl, J. Gerloff, H. Heyinig, \& D. Mollenhauer (Stuttgart; New York, NY: Gustav Fischer Verlag) Laing TE, Ru KM, Smol JP. 1999. Past environmental and climatic changes related to tree-line shifts inferred from fossil diatoms from a lake near the Lena River Delta, Siberia. The Holocene, $5,547-557$.

Lange-Bertalot H. 1979. Pollution tolerance as a criterion for water quality estimation. Nova Hedwigia 64:285-304

Lange-Bertalot H. 2001. Diatoms of Europe Vol. 2: Navicula sensu stricto. 10 Genera Separated from Navicula sensu lato. Frustulia. A.R.G. Ganter Verlag K.G., Ruggell, Liechtenstein 
Le Blanc M, Gajewski K, Hamilton PB. 2004. A diatom-based Holocene palaeoenvironmental record from a mid-arctic lake on Boothia Peninsula, Nunavut, Canada. The Holocene, 14(3), 417-425. http://doi.org/10.1191/0959683604hl717rp

Lerbekmo JF, Campbell FA. 1968. Distribution, composition, and source of the White River Ash, Yukon Territory. Canadian Journal of Earth Sciences, 109, 109-116.

Lerbekmo JF, Westgate JA, Smith DGW, Denton GH. 1975. New data on the character and history of the White River volcanic eruption, Alaska: in Quaternary studies: selected papers from IX INQUA congress, Royal Society of New Zealand Bulletin 0013, p. 203-209.

Lerbekmo JF. 2008. The White river ash: largest Holocene Plinian tephra. Canadian Journal of Earth Science, 45, 693-700

Leuz AK, Mönch H, Johnson CA. 2006. Sorption of Sb(III) and Sb(V) to Goethite: Influence on Sb(III) Oxidation and Mobilization. Environmental Science \& Technology, 40(23), 7277-7282. http://doi.org/10.1021/es061284b

Lim DSS, Smol JP, Douglas MSV. 2008. Recent environmental changes on Banks Island (N.W.T., Canadian Arctic) quantified using fossil diatom assemblages. Journal of Paleolimnology, 40(1), 385-398. https://doi.org/10.1007/s10933-007-9168-0

Lim D, Douglas M, Smol J. 2001. Diatoms and their relationship to environmental variables from lakes and ponds on Bathust Island, Nunavut, Canadian High Arctic. Hydrobiologia, 450, 215-230. Retrieved from file://c/My Documents/Sofie Docs/Articles/Phytoplankton diversity/Lim2001.pdf

Lotter AF, Eicher U, Siegenthaler U, Birks HJB. 1992. Late-glacial climatic oscillations as recorded in Swiss lake sediments. Journal of Quaternary Science, 7(3), 187-204. http://doi.org/10.1002/jqs.3390070302 
Lotter AF, Bigler C. 2000. Do diatoms in the Swiss Alps reflect the length of ice-cover? Aquatic Sciences, 62(2), 125-141. https://doi.org/10.1007/s000270050002

Lotter AF, Birks HJB. 1993. The impact of the Laacher See Tephra on terrestrial and aquatic ecosystems in the Black Forest, southern Germany. Journal of Quaternary Science, 8, 263-276.

Lotter AF, Birks HJB, Zolitschka B. 1994. Late-glacial pollen and diatom changes in response to two different environmental perturbations: volcanic eruption and Younger Dryas cooling. Journal of Paleolimnology, 15(3), 229-245. https://doi.org/10.1016/0167-9236(95)00013-V Lotter AF, Birks HJB, Hofmann W, Marchetto A. 1998. Modern diatom, cladocera, chironomid, and chrysophyte cyst assemblages as quantitative indicators for the reconstruction of past environmental conditions in the Alps. II. Nutrients. Journal of Paleolimnology, 19(4), 443-463. http://doi.org/10.1023/A:1007994206432

Macdonald RW, Harner T, Fyfe J. 2005. Recent climate change in the Arctic and its impact on contaminant pathways and interpretation of temporal trend data. Science of the Total Environment, 342(1-3), 5-86. https://doi.org/10.1016/j.scitotenv.2004.12.059

Macumber AL, Patterson RT, Neville LA, Falck H. 2011. A sledge microtome for high resolution subsampling of freeze cores. Journal of Paleolimnology, 45(2), 307-310. http://doi.org/10.1007/s10933-010-9487-4

Macumber, AL, Patterson RT, Galloway JM, Falck H, Swindles GT. 2018. Reconstruction of Holocene hydroclimatic variability in subarctic treeline lakes using lake sediment grain-size endmembers. Holocene, 28(6), 845-857. https://doi.org/10.1177/0959683617752836

Manabe S, Spelman MM, Stouffer RJ. 1992. Transient responses of a coupled ocean-atmosphere model to gradual changes in atmospheric CO2. Journal of Climate. 5:105-26. 
Mann ME, Zhang Z, Rutherford S, Bradley RS, Hughes MK, Shindell D, Ammann C, Faluvegi

G, Ni F (2009) Global signatures and dynamical origins of the Little Ice Age and Medieval

Climate Anomaly. Science 326:1256-1260

Mitchell JFB, Johns TC, Gergory JM, Tett SFB. Climate response to increasing levels of greenhouse gases and sulphate aerosols. Nature 1995;376:501-4.

Murray, M., 2002. Is laser particle size determination possible for carbonate-rich lake sediments? Journal of Paleolimnology 27, 173-183

Naeher S, Gilli A, North RP, Hamann Y, Schubert CJ. 2013. Tracing bottom water oxygenation with sedimentary Mn/Fe ratios in Lake Zurich, Switzerland. Chemical Geology, 352, 125-133. https://doi.org/10.1016/j.chemgeo.2013.06.006

Neff JC, Ballantyne AP, Farmer GL, Mahowald NM, Conroy JL, Landry CC, Overpeck JT, Overpeck J, Hughen K, Hardy D, Bradley R, Case R, Douglas M, Finney B, Gajewski K, Jacoby G, Jennings A, Lamoureux S, Lasca A, MacDonald G, Moore J, Retelle M, Smith S, Wolfe A, Zielinski G. 1997. Arctic environmental change of the last four centuries. Science 278(5341), 1251-1256. https://doi.org/10.1126/science.278.5341.1251

Paliy O, Shankar V. 2016. Application of multivariate statistical techniques in microbial ecology. Molecular Ecology, 25: 1032-1057. doi:10.1111/mec.13536

Patterson RT, Crann CA, Cutts JA, Courtney Mustaphi CJ, Nasser NA, Macumber AL, Galloway J, Swindles P, Falck H. 2017. New occurrences of the White River Ash (east lobe) in Subarctic Canada and utility for estimating freshwater reservoir effect in lake sediment archives. Palaeogeography, Palaeoclimatology, Palaeoecology, 477, 1-9.

http://doi.org/10.1016/j.palaeo.2017.03.031 
Pienitz R, Smol JP, Birks HJB. 1995. Assessment of freshwater diatoms as quantitative indicators of past climatic change in the Yukon and Northwest Territories, Canada. Journal of Paleolimnology, 13(1), 21-49. https://doi.org/10.1007/BF00678109

Pienitz R, Smol JP, Macdonaldt GM. 1999. Paleolimnological Reconstruction of Holocene Climatic Trends from Two Boreal Treeline Lakes, Northwest Territories, Canada. Arctic, Antarctic, and Alpine Research, 31(1), 82-83.

Reimer PJ, Bard E, Bayliss A, Beck WJ, Blackwell PG, Bronk Ramsey C, Buck CE, Cheng H, Lawrence ER, Friedrich M, Grootes PM, Guilderson TP, Haflidason H, Hajdas I, Hatté C, Heaton TJ, Hoffmann DL, Hogg AG, Hughen KA, Kaiser FK, Kromer B, Manning SW, Niu M, Reimer RW, Richards DA, Scott ME, Southon JR, Staff RA, Turney CSM, van der Plicht J. 2013. IntCal13 andMarine13 radiocarbon age calibration curves $0-50,000$ years cal BP. Radiocarbon 55, 1869-1887.

Ritchie VJ, Ilgen AG, Mueller SH, Trainor TP, Goldfarb RJ. 2013. Mobility and chemical fate of antimony and arsenic in historic mining environments of the Kantishna Hills district, Denali National Park and Preserve, Alaska. Chemical Geology, 335, 172-188.

http://doi.org/10.1016/j.chemgeo.2012.10.016

Robinson SD. 2001. Extending the late Holocene White River ash distribution, northwestern Canada. Arctic, 54(2), 157-161.

Robock A, Mao J. 1995. The Volcanic Signal in Surface Temperature Observations. Journal of Climate. 8, 1086-1103.

Rühland K, Smol JP. 2005. Diatom shifts as evidence for recent Subarctic warming in a remote tundra lake, NWT, Canada. Palaeogeography, Palaeoclimatology, Palaeoecology, 226(1-2), 116. http://doi.org/10.1016/j.palaeo.2005.05.001 
Saros JE, Anderson NJ. 2015. The ecology of the planktonic diatom Cyclotella and its implications for global environmental change studies. Biological Reviews, 90(2), 522-541.

\section{https://doi.org/10.1111/brv.12120}

Siver PA, Hamilton PB, Stachura-Suchoples K, Kociolek KP. 2005. Diatoms of North America: the freshwater flora of Cape Cod, Massachusetts, U.S.A. Iconographia Diatomologica 14: 1-463 Smedley PL, Kinniburgh DG. 2002. A review of the source, behaviour and distribution of arsenic in natural waters. Applied Geochemistry, 17, 517-568. https://doi.org/10.1016/S0883-

\section{7(02)00018-5}

Smetacek V. 1999. Diatoms and the ocean carbon cycle. Protist, 150, 25-32.

Spence C. 2006. Hydrological processes and streamflow in a lake dominated watercourse.

Hydrological Processes, 20, 3665-3681. http://doi.org/10.1002/hyp

Spence CS, Kokelj V, Kokelj SA, McCluskie M, Hedstrom N. 2015. Evidence of a change in water chemistryin Canada's subarctic associatedwith enhanced winter streamflow, Journal of Geophysics Research: Biogeosciences 120,113-127,doi:10.1002/2014JG002809

Staudigel H, Yayanos A, Chastain R, Davies G, Verdurmen EAT, Schiffman P, Bourcier R, De Baar H. 1998. Biologically mediated dissolution of volcanic glass in seawater. Earth and Planetary Science Letters, 164, 233-244.

Steinhilber F, Beer J, Fröhlich C. 2009. Total solar irradiance during the Holocene. Geophysical Research Letters, 36(19):L19704.

Szczepocka E, Szulc B. 2009. The use of benthic diatoms in estimating water quality of variously polluted rivers. Oceanological and Hydrobiological Studies, 38(1), 17-26.

https://doi.org/10.2478/v10009-009-0012-x 
Telford RJ, Barker P, Metcalfe S, Newton A. 2004. Lacustrine responses to tephra deposition: Examples from Mexico. Quaternary Science Reviews, 23(23-24), 2337-2353.

\section{http://doi.org/10.1016/j.quascirev.2004.03.014}

Thorseth IH, Furnes H, Tumyr O. 1995. Textural and chemical effects of bacterial activity on basaltic glass: an experimental approach. Chemical Geology 119, 139-160.

Tilling RI, Lipman PW. 1993. Lessons in reducing volcanic risk. Nature, v. 364, 277-280. https://doi.org/10.1038/364277a0

Upiter LM, Vermaire JC, Patterson RT, Crann CA, Galloway JM, Macumber AL, Neville LA, Swindles GT, Falck H, Roe HM, Pisaric MFJ. 2014. Middle to late Holocene chironomidinferred July temperatures for the central Northwest Territories, Canada. Journal of Paleolimnology, 52(1-2), 11-26. https://doi.org/10.1007/s10933-014-9775-5

Urrutia R, Araneda A, Cruces F, Torres L, Chirinos L, Treutler HC, Chapron E. 2007. Changes in diatom, pollen, and chironomid assemblages in response to a recent volcanic event in Lake Galletue (Chilean Andes). Limnologica, 37(1), 49-62.

http://doi.org/10.1016/j.1imno.2006.09.003

Van Hengstum PJ, Reinhardt EG, Boyce JI, Clark C. 2007. Changing sedimentation patterns due to historical land-use change in Frenchman's Bay, Pickering, Canada: Evidence from highresolution textural analysis. Journal of Paleolimnology, 37(4), 603-618. https://doi.org/10.1007/s10933-006-9057-y

White AF, Blum AE. 1995. Effects of climate on chemical weathering in watersheds. Geochimica et Cosmochimica Acta 59, 1729-47. 
Walker GPL, Croasdale R. 1971. Two Plinian-type eruptions in the Azores. Journal of the Geological Society, 127(1), 17 LP-55. Retrieved from

http://jgs.lyellcollection.org/content/127/1/17.abstract

Weckstrom J, Korhola A, Blom T. 1997. Diatoms as quantitative indicators of $\mathrm{pH}$ and water temperature in subarctic Fennoscandian lakes. Hydrobiologia, 347, 171-184.

https://doi.org/10.1023/A:1003091923476

Winder M, Reuter JE, Schladow SG. 2009. Lake warming favours small-sized planktonic diatom species. Proceedings. Biological Sciences / The Royal Society, 276(1656), 427-435.

http://doi.org/10.1098/rspb.2008.1200

West KD, Donaldson JA. 2002. Resedimentation of the late Holocene White River tephra, Yukon Territory and Alaska. Yukon Exploration and Geology. Whitehorse: Exploration and Geological Services Division. p.239 - 247.

West KD. 2007. Resedimentation of the late Holocene White River ash, Yukon Territory, Canada and Alaska, United States: Carleton University (Canada).

Wetzel RG. 1983. Periphyton of Aquatic Ecosystems. The Hague: B.V. Junk Publishers. Wolfe BB, Edwards TWD, Aravena R, Macdonaldt GM. 1996. Rapid Holocene hydrologic change along boreal treeline revealed by $513 \mathrm{C}$ and 6180 in organic lake sediments, Northwest Territories, Canada. Journal of Paleolimnology, 171-181. https://doi.org/10.1007/BF00196779 Wolff-Boenisch D, Gislason SR, Oelkers EH. 2004a. The effect of fluoride on the dissolution rates of natural glasses at $\mathrm{pH} 4$ and $25^{\circ} \mathrm{C}$. Geochimica et Cosmochimica Acta, 68(22), 45714582. https://doi.org/https://doi.org/10.1016/j.gca.2004.05.026 
Wolff-Boenisch D, Gislason SR, Oelkers EH, Putnis CV. 2004b. The dissolution rates of natural glasses as a function of their composition at $\mathrm{pH} 4$ and 10.6, and temperatures from 25 to $74^{\circ} \mathrm{C}$. Geochimica et Cosmochimica Acta, 68, 4843-4858

Yamashita K, Creaser RA, Stemler JU, Zimaro TW. 1999. Geochemical and Nd-Pb iso-topic systematics of late Archean granitoids, southwestern Slave Province, Canada: constraints for granitoid origin and crustal isotopic structure. Canadian Journal of Earth Science. 36, 11311147.

Żarczyński M, Wacnik A, Tylmann W. 2019. Tracing lake mixing and oxygenation regime using the $\mathrm{Fe} / \mathrm{Mn}$ ratio in varved sediments: 2000 year-long record of human-induced changes from Lake Żabińskie (NE Poland). Science of the Total Environment, 657, 585-596.

https://doi.org/10.1016/j.scitotenv.2018.12.078

Zwiers FW. 2002. The 20-year forecast. Nature, 416, 690-691 


\section{Appendix A: Comprehensive Diatom Counts for PKT_2FR2}

Diatom taxa were identified with reference to photomicrographs of taxa from similar geographic regions and environmental conditions (Krammer and Lange-Bertalot, 1985-1991; Hartley, 1996). Species names were then corrected to current taxonomic nomenclature following Algaebase (Guiry and Guiry, 2018). This dataset is relevant to chapter 2. 


\begin{tabular}{|c|c|c|c|c|c|c|c|c|c|c|c|c|c|}
\hline $\begin{array}{l}\text { Updated Species Name (Guiry and Guiry, } \\
\text { 2018) }\end{array}$ & $\begin{array}{l}\text { Dep } \\
\text { (cm } \\
13\end{array}$ & 14 & 15 & 16 & 17 & 18 & 19 & 20 & 21 & 22 & 23 & 24 & 25 \\
\hline Achnanthidium atomus & 12 & 18 & 1 & 19 & 2 & 22 & 24 & 12 & 26 & 11 & 21 & 9 & 5 \\
\hline $\begin{array}{l}\text { Achnanthidium minutissimum } \\
\text { Achnanthidium sp6 }\end{array}$ & 4 & 15 & 15 & 15 & 21 & 15 & 23 & 2 & 11 & 16 & 8 & 17 & 9 \\
\hline Achnanthidium sp7 & & & & & & & & & 1 & 1 & & & \\
\hline Amphora ovalis & & & & & & & & 1 & & 1 & & & \\
\hline Aneumastus sp1 & & & & & & & & & & & & 1 & \\
\hline Brachysira microcephala & 69 & 113 & 73 & 84 & 86 & 51 & 83 & 73 & 81 & 75 & 68 & 58 & 53 \\
\hline Cyclostephanos invisitatus & & & & 1 & 1 & 3 & 2 & & & & & 4 & 2 \\
\hline Cyclotella distinguenda & 6 & 6 & 1 & 3 & 1 & 1 & 1 & 1 & 2 & 1 & & & 3 \\
\hline Cyclotella intermedia & 3 & 44 & 25 & 26 & 17 & 4 & 8 & 9 & 14 & 1 & 1 & 6 & 13 \\
\hline Cyclotella sp6 & & & & & & & 1 & 2 & & & & & 1 \\
\hline Cymbella sp1 & 3 & 9 & 9 & 5 & 5 & 1 & 2 & 3 & & 1 & 2 & & 3 \\
\hline Cymbopleura angustata & & & & 1 & 2 & 3 & 3 & 2 & 2 & 3 & 4 & 3 & 3 \\
\hline Cymbopleura ehrenbergii & & 1 & 1 & 1 & 2 & 3 & 3 & 2 & & & 1 & 1 & \\
\hline Cymbopleura sp2 & & & & & 1 & & 1 & 3 & 2 & & & 1 & 6 \\
\hline Denticula elegans & 4 & 4 & 1 & 7 & 6 & 1 & 9 & 2 & 6 & 6 & & 4 & \\
\hline Dipuneis occulata & & & & & 1 & & 2 & 4 & 4 & 7 & 8 & 11 & 6 \\
\hline Discostella pseudostelligera & 13 & 2 & 12 & 11 & 12 & & 1 & 17 & 1 & 8 & 7 & 9 & 27 \\
\hline Discostella stelligera & 15 & 16 & 6 & 17 & 21 & 19 & 3 & 25 & 7 & 17 & 32 & 25 & 49 \\
\hline $\begin{array}{l}\text { Encyonema cesatii sensu strata } \\
\text { Encyonema elginese }\end{array}$ & 3 & 2 & & 1 & 2 & & 3 & 6 & 3 & 5 & 6 & 8 & 3 \\
\hline $\begin{array}{l}\text { Encyonema silesiacum } \\
\text { Encyonema sp3 }\end{array}$ & & 1 & 1 & & 1 & & & 1 & 4 & 4 & & 1 & \\
\hline Encyonema sp5 & & & & & & & & & 5 & & 1 & & 2 \\
\hline Encyonema minuta & & & & & & & & & & & & & \\
\hline Encyonema silicum & & & & & & & & & & & & & 1 \\
\hline Encyonopsis cesetii & & & & & & & & 1 & & 2 & 1 & 1 & \\
\hline Encyonopsis falaisensis & 4 & 7 & 4 & 6 & 8 & 6 & 1 & 9 & 2 & 5 & 4 & 13 & 5 \\
\hline Encyonopsis microcephala & 13 & 26 & 19 & 24 & 31 & 24 & 35 & 29 & 49 & 31 & 32 & 31 & 48 \\
\hline Fragillaria sp1 & & 1 & 1 & & 1 & & & 1 & & & 4 & 3 & \\
\hline Frustrulia vulgaris & & & & & & & & & & & & & \\
\hline Gomphoneis sp1 & & & & & & & & & & & & & \\
\hline Hantzschia amphioxys & & & & & & & & & & & & & \\
\hline Lindavia michiganiana & 33 & 45 & 24 & 3 & 28 & 13 & 27 & 28 & 23 & 31 & 18 & 24 & 26 \\
\hline Mayamaea sp1 & 1 & 4 & 4 & 2 & 2 & & & & & & & & \\
\hline
\end{tabular}




\begin{tabular}{|c|c|c|c|c|c|c|c|c|c|c|c|c|c|}
\hline $\begin{array}{l}\text { Updated Species Name (Guiry and Guiry, } \\
\text { 2018) }\end{array}$ & $\begin{array}{c}\begin{array}{c}\text { Dept } \\
\text { (cm) }\end{array} \\
13\end{array}$ & 14 & 15 & 16 & 17 & 18 & 19 & 20 & 21 & 22 & 23 & 24 & 25 \\
\hline Navicula antonii & 4 & 4 & 1 & 5 & 3 & 6 & 5 & 1 & 3 & 2 & & 3 & \\
\hline Navicula cryptocephala & 1 & 9 & 1 & 5 & 8 & 1 & 6 & 8 & 12 & 5 & 12 & 1 & 15 \\
\hline Navicula cryptotenella & 4 & 5 & 22 & 32 & 23 & 1 & 2 & 2 & 26 & 4 & 39 & 32 & 23 \\
\hline Navicula gomphonema & & & & & & 1 & 1 & & 2 & 1 & 3 & & \\
\hline Nupela impexiformis & 1 & 14 & 7 & 7 & 3 & & & & & & & & \\
\hline Navicula notha & 1 & 4 & 4 & 1 & 12 & 18 & 15 & 4 & 12 & 9 & 4 & 2 & 11 \\
\hline Navicula Radiosa & & & & & & & & & 4 & 2 & 1 & 1 & \\
\hline Navicula schweigeri & 1 & 27 & 24 & 15 & 17 & 1 & 1 & 15 & 15 & 1 & 7 & 7 & 17 \\
\hline Navicula wildii & 3 & 2 & & 4 & 5 & 7 & 8 & 5 & 5 & 7 & 6 & 6 & 16 \\
\hline Navicula sp4 & 3 & 2 & & 1 & & & & 1 & 2 & 1 & & 5 & \\
\hline Navicula sp8 & & 9 & 12 & 13 & 17 & 18 & 18 & 8 & 6 & 14 & 9 & 13 & 5 \\
\hline Navicula sp9 & & & & 1 & 3 & 3 & 5 & 5 & 2 & & 7 & 4 & 14 \\
\hline Navicula sp 10 & & & & & & & & & & & 1 & & \\
\hline Navicula sp12 & & & & & & 1 & 1 & & & & & & \\
\hline Navicula sp13 & 1 & 4 & 4 & 2 & 2 & & 1 & 2 & 1 & 1 & & & \\
\hline Navicula sp14 & & & & & 2 & & 3 & 6 & & & & 1 & \\
\hline Neidium afinne & & 2 & 3 & 3 & 4 & 6 & 4 & & & & & & \\
\hline Neidium sp2 & 7 & 12 & 7 & 8 & 5 & 4 & 3 & & & & & & \\
\hline Nitzschia amphibia & & & & & & & & & 3 & 2 & & & \\
\hline Nitzschia minuta & & & & 3 & 4 & 7 & 6 & 2 & 8 & 2 & 2 & 2 & \\
\hline Nitzchia palacea & 1 & 2 & 1 & 1 & 1 & 1 & 1 & & & & & & \\
\hline Nitzschia palea sensu lato & 4 & 5 & 22 & 49 & 59 & 49 & 76 & 64 & 46 & 51 & 71 & 53 & 5 \\
\hline Nitzschia recta & 3 & 11 & 12 & 7 & 1 & 3 & 7 & 8 & 6 & & 5 & & \\
\hline Nitzschia sp6 & & 2 & 3 & 1 & 1 & & & & & & & & \\
\hline Pinnularia biceps (var 1) & & 4 & 6 & 2 & 3 & & 1 & 2 & 5 & & 1 & 4 & \\
\hline \multicolumn{14}{|l|}{ Pinnularia biceps (var 2) } \\
\hline Pinnularia sp4 & & & & & & & & & & & 1 & & \\
\hline Pinnularia sp5 & 1 & 1 & & & & & & & & & & & \\
\hline \multicolumn{14}{|l|}{ Pinnularia sp6 } \\
\hline Psamnothidium sp1 & & 1 & 1 & & & & & & & & & & \\
\hline Pseudostaurosira brevistriata & & & & 2 & 2 & 6 & 4 & & & & & & \\
\hline Rhopalodia gibba & 4 & 4 & 1 & 2 & & & & & & & 1 & & \\
\hline Rossitidium petersonii & & 1 & 1 & 1 & 1 & 1 & 1 & & 4 & & & & 2 \\
\hline Sellaphora capitata & & & & & & & & & & & 1 & & \\
\hline Sellaphora pupula & 4 & 7 & 4 & 11 & 12 & 16 & 15 & 6 & 7 & 3 & 3 & 9 & 5 \\
\hline
\end{tabular}




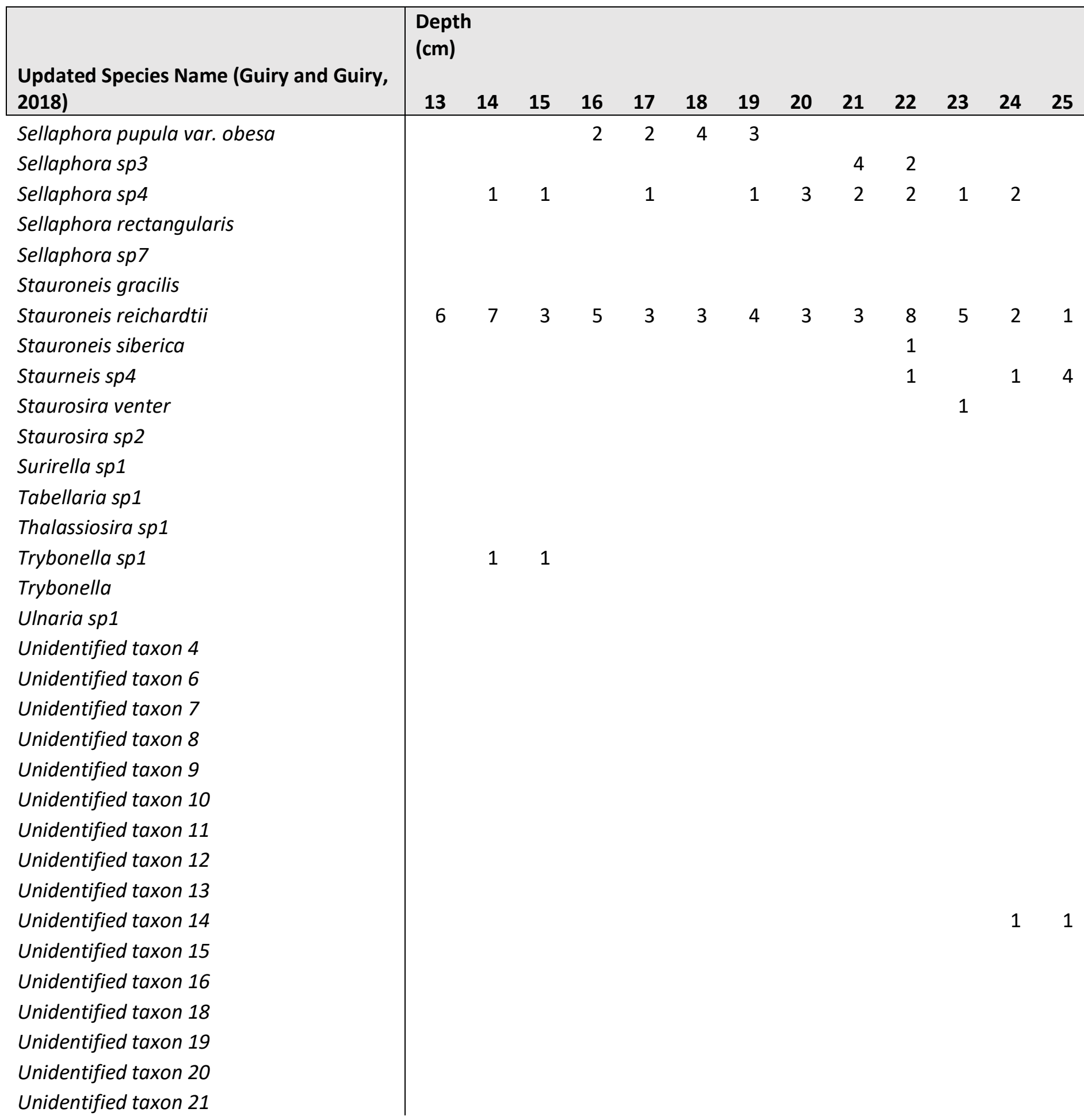




\begin{tabular}{|c|c|c|c|c|c|c|c|c|c|c|}
\hline Updated Species Name (Guiry and Guiry, 2018) & $\begin{array}{c}\begin{array}{c}\text { Dept } \\
\text { (cm) } \\
26\end{array} \\
\end{array}$ & 27 & 28 & 29 & 30 & 31 & 32 & 33 & 34 & 35 \\
\hline Achnanthidium atomus & 8 & 15 & 11 & 8 & 17 & 15 & 15 & 3 & 15 & 19 \\
\hline Achnanthidium minutissimum & 17 & 9 & 11 & 15 & 14 & 6 & 11 & 7 & 18 & 17 \\
\hline Achnanthidium sp6 & & & & & & & & & & 1 \\
\hline \multicolumn{11}{|l|}{ Achnanthidium sp7 } \\
\hline \multicolumn{11}{|l|}{ Amphora ovalis } \\
\hline \multicolumn{11}{|l|}{ Aneumastus sp1 } \\
\hline Brachysira microcephala & 57 & 49 & 55 & 64 & 71 & 39 & 72 & 43 & 86 & 71 \\
\hline Cyclostephanos invisitatus & 9 & 5 & 3 & 1 & 1 & 1 & 2 & 1 & 1 & \\
\hline Cyclotella distinguenda & & 2 & 2 & 3 & 1 & & & & & \\
\hline Cyclotella intermedia & 3 & 1 & 11 & 14 & 12 & 4 & 1 & 7 & 1 & 6 \\
\hline \multicolumn{11}{|l|}{ Cyclotella sp6 } \\
\hline Cymbella sp1 & 2 & 5 & 3 & 2 & 3 & 3 & 5 & 3 & 3 & 2 \\
\hline Cymbopleura angustata & 1 & 5 & 7 & 1 & 7 & 1 & 3 & 3 & 9 & 1 \\
\hline Cymbopleura ehrenbergii & 1 & 2 & 1 & 2 & 2 & 1 & 2 & 1 & 1 & \\
\hline Cymbopleura sp2 & & 2 & 2 & 3 & 9 & 9 & 9 & 1 & 4 & 4 \\
\hline Denticula elegans & 1 & & & & 1 & 1 & 3 & 3 & 4 & 3 \\
\hline Dipuneis occulata & 5 & 5 & 2 & & & & & & & \\
\hline Discostella pseudostelligera & 7 & 7 & 3 & & & & & & 2 & 3 \\
\hline Discostella stelligera & 4 & 38 & 35 & 33 & 56 & 43 & 46 & 9 & 9 & 2 \\
\hline Encyonema cesatii sensu strata & 3 & 5 & 4 & 4 & 3 & 1 & 5 & 4 & 3 & \\
\hline \multicolumn{11}{|l|}{ Encyonema elginese } \\
\hline Encyonema silesiacum & 1 & 1 & & 1 & 1 & 1 & 1 & & 1 & 2 \\
\hline Encyonema sp3 & & & & & & & 1 & 1 & 1 & \\
\hline Encyonema sp5 & & 2 & 1 & 2 & 3 & 3 & 11 & 1 & 9 & 1 \\
\hline Encyonema minuta & & & & 2 & 1 & & & & & \\
\hline \multicolumn{11}{|l|}{ Encyonema silicum } \\
\hline Encyonopsis cesetii & 1 & & & & & & & & 2 & 4 \\
\hline Encyonopsis falaisensis & 9 & 8 & 8 & 9 & 1 & 6 & 6 & 1 & 3 & 3 \\
\hline Encyonopsis microcephala & 27 & 3 & 36 & 45 & 4 & 16 & 39 & 28 & 45 & 31 \\
\hline Fragillaria sp1 & & & & 1 & & & & & 2 & 3 \\
\hline \multicolumn{11}{|l|}{ Frustrulia vulgaris } \\
\hline \multicolumn{11}{|l|}{ Gomphoneis sp1 } \\
\hline Hantzschia amphioxys & & & & 2 & 1 & & & & & \\
\hline Lindavia michiganiana & 29 & 24 & 32 & 43 & 49 & 28 & 43 & 21 & 4 & 33 \\
\hline Mayamaea sp1 & & & & & 3 & 4 & 6 & 3 & 3 & 2 \\
\hline
\end{tabular}




\begin{tabular}{|c|c|c|c|c|c|c|c|c|c|c|}
\hline Updated Species Name (Guiry and Guiry, 2018) & $\begin{array}{c}\text { Dept } \\
\text { (cm) } \\
26\end{array}$ & 27 & 28 & 29 & 30 & 31 & 32 & 33 & 34 & 35 \\
\hline Navicula antonii & 2 & 2 & 1 & 1 & & & 3 & 4 & 9 & 8 \\
\hline Navicula cryptocephala & 24 & 9 & 5 & 1 & 4 & 4 & 3 & & 7 & 11 \\
\hline Navicula cryptotenella & 38 & 31 & 42 & 57 & 5 & 19 & 38 & 24 & 33 & 19 \\
\hline Navicula gomphonema & 4 & & & & 1 & 1 & 3 & 3 & 2 & \\
\hline Nupela impexiformis & & & & & 5 & 6 & 11 & 7 & 6 & \\
\hline Navicula notha & 7 & 3 & 4 & 7 & 1 & 7 & 22 & 18 & 25 & 14 \\
\hline Navicula Radiosa & 1 & 3 & 1 & & 3 & 4 & 7 & 4 & 5 & 2 \\
\hline Navicula schweigeri & 1 & 11 & 17 & 25 & 25 & 12 & 3 & 22 & 35 & 23 \\
\hline Navicula wildii & 12 & 27 & 16 & 6 & 18 & 18 & 25 & 1 & 2 & 17 \\
\hline Navicula sp4 & 1 & 2 & 1 & 1 & & & 3 & 4 & 4 & 1 \\
\hline Navicula sp8 & 1 & 2 & 2 & 3 & 9 & 9 & 17 & 1 & 18 & 14 \\
\hline Navicula sp9 & 5 & & & & 1 & 1 & 1 & & 6 & 9 \\
\hline Navicula sp 10 & & & & 1 & & & & & & \\
\hline \multicolumn{11}{|l|}{ Navicula sp12 } \\
\hline Navicula sp13 & & & & 1 & & & & & & \\
\hline Navicula sp14 & 4 & & 1 & 4 & 2 & & & & & 1 \\
\hline Neidium afinne & & & & & & & 3 & 4 & 4 & 1 \\
\hline Neidium sp2 & & & 2 & 5 & 5 & 3 & 9 & 7 & 11 & 8 \\
\hline Nitzschia amphibia & 1 & & & & & & 1 & 1 & 1 & 1 \\
\hline Nitzschia minuta & 1 & & 1 & 4 & 4 & 3 & 5 & 3 & 7 & 7 \\
\hline \multicolumn{11}{|l|}{ Nitzchia palacea } \\
\hline Nitzschia palea sensu lato & 55 & 65 & 64 & 66 & 77 & 45 & 83 & 49 & 9 & 7 \\
\hline Nitzschia recta & & & 1 & 4 & 7 & 6 & 5 & & & \\
\hline \multicolumn{11}{|l|}{ Nitzschia sp6 } \\
\hline Pinnularia biceps (var 1) & 2 & 3 & 1 & & 1 & 1 & 3 & 3 & 2 & \\
\hline \multicolumn{11}{|l|}{ Pinnularia biceps (var 2) } \\
\hline \multicolumn{11}{|l|}{ Pinnularia sp4 } \\
\hline \multicolumn{11}{|l|}{ Pinnularia sp5 } \\
\hline \multicolumn{11}{|l|}{ Pinnularia sp6 } \\
\hline \multicolumn{11}{|l|}{ Psamnothidium sp1 } \\
\hline Pseudostaurosira brevistriata & & & & 2 & 1 & & & & & \\
\hline Rhopalodia gibba & 2 & 4 & 3 & 2 & 6 & 6 & 5 & & & \\
\hline Rossitidium petersonii & & 1 & & & & & & & 2 & 3 \\
\hline Sellaphora capitata & 1 & & & & & & & & & 1 \\
\hline Sellaphora pupula & 8 & 6 & 5 & 5 & 3 & & & & 4 & 7 \\
\hline
\end{tabular}




\begin{tabular}{|c|c|c|c|c|c|c|c|c|c|c|}
\hline Updated Species Name (Guiry and Guiry, 2018) & \multicolumn{10}{|c|}{$\begin{array}{l}\text { Depth } \\
\text { (cm) }\end{array}$} \\
\hline Sellaphora pupula var. obesa & & & & 2 & 1 & & 2 & 3 & 3 & 1 \\
\hline Sellaphora sp3 & 3 & 2 & 1 & 1 & & & & & & \\
\hline Sellaphora sp4 & & & & & & & & & & \\
\hline Sellaphora rectangularis & & 6 & 3 & & & & & & & \\
\hline Sellaphora sp7 & & & & & & & & & & \\
\hline Stauroneis gracilis & & & & & & & & & & \\
\hline Stauroneis reichardtii & 1 & 3 & 3 & 4 & 2 & & 1 & 1 & 4 & 5 \\
\hline Stauroneis siberica & & & & 1 & & & & & & 1 \\
\hline Staurneis sp 4 & 2 & 8 & 4 & & & & & & & \\
\hline Staurosira venter & 2 & & & & & & & & & \\
\hline Staurosira sp2 & & & & & & & & & & \\
\hline Surirella sp1 & & & & & & & & & & \\
\hline Tabellaria sp1 & & & & & & & & & & \\
\hline Thalassiosira sp1 & & & & & & & & & & \\
\hline Trybonella sp1 & & & & & & & & & & \\
\hline Trybonella & & & & & & & & & & \\
\hline Ulnaria sp1 & & & & & & & & & & \\
\hline Unidentified taxon 4 & & & & & & & & & & \\
\hline Unidentified taxon 6 & & & & & & & & & & \\
\hline Unidentified taxon 7 & & & & & & & & & & \\
\hline Unidentified taxon 8 & & & & & & & & & & \\
\hline Unidentified taxon 9 & & & & & & & & & & \\
\hline Unidentified taxon 10 & & & & & & & & & & \\
\hline Unidentified taxon 11 & & & & 2 & 1 & & & & & \\
\hline Unidentified taxon 12 & & & & & & & & & & \\
\hline Unidentified taxon 13 & & & & & & & & & & \\
\hline Unidentified taxon 14 & & & & & & & & & & \\
\hline Unidentified taxon 15 & & & & & & & & & & \\
\hline Unidentified taxon 16 & & & & & & & & & & \\
\hline Unidentified taxon 18 & & & & & & & & & & \\
\hline Unidentified taxon 19 & & & & & & & & & & \\
\hline Unidentified taxon 20 & & & & & & & & & & \\
\hline Unidentified taxon 21 & & & & & & & & & & \\
\hline
\end{tabular}




\begin{tabular}{|c|c|c|c|c|c|c|c|c|c|c|c|}
\hline \multirow[b]{2}{*}{ Updated Species Name (Guiry and Guiry, 2018) } & \multicolumn{11}{|c|}{ Depth (cm) } \\
\hline & 36 & 37 & 38 & 39 & 40 & 41 & 42 & 43 & 44 & 45 & 46 \\
\hline Achnanthidium atomus & 25 & 1 & 2 & 32 & 26 & 21 & 34 & 23 & 23 & 22 & 36 \\
\hline Achnanthidium minutissimum & 6 & 13 & 2 & 1 & 12 & 13 & 6 & 15 & 6 & 12 & 13 \\
\hline \multicolumn{12}{|l|}{ Achnanthidium sp6 } \\
\hline \multicolumn{12}{|l|}{ Achnanthidium sp7 } \\
\hline Amphora ovalis & & & & & & & & 1 & & & \\
\hline \multicolumn{12}{|l|}{ Aneumastus sp1 } \\
\hline Brachysira microcephala & 59 & 77 & 87 & 14 & 62 & 62 & 48 & 63 & 64 & 76 & 9 \\
\hline Cyclostephanos invisitatus & & 2 & & & & & 2 & & & & \\
\hline Cyclotella distinguenda & 3 & & 1 & & & & & 1 & 1 & & \\
\hline Cyclotella intermedia & 28 & 7 & & & & 8 & 3 & & 7 & 5 & 13 \\
\hline Cyclotella sp6 & & & 9 & 6 & & & & & & & \\
\hline Cymbella sp1 & 3 & 4 & 2 & 1 & & & 3 & 1 & 3 & 1 & \\
\hline Cymbopleura angustata & 7 & 3 & & 3 & 5 & 7 & 4 & 5 & 7 & 5 & 4 \\
\hline Cymbopleura ehrenbergii & 2 & 1 & & & 1 & & & 1 & 3 & & 4 \\
\hline Cymbopleura sp2 & 5 & 1 & & 1 & 2 & 2 & & 9 & 4 & 1 & \\
\hline Denticula elegans & & 6 & 2 & 1 & & & & & 4 & & \\
\hline \multicolumn{12}{|l|}{ Dipuneis occulata } \\
\hline Discostella pseudostelligera & 1 & 13 & 18 & 16 & 6 & 2 & 4 & 1 & 4 & 12 & 1 \\
\hline Discostella stelligera & 14 & 16 & 57 & 39 & & 2 & 1 & 5 & 3 & 1 & 7 \\
\hline Encyonema cesatii sensu strata & 1 & 3 & 2 & 4 & 5 & 4 & 1 & 1 & 2 & 3 & 4 \\
\hline \multicolumn{12}{|l|}{ Encyonema elginese } \\
\hline Encyonema silesiacum & & 1 & 2 & 1 & & & & 1 & & & \\
\hline Encyonema sp3 & 3 & & & & & & & & & & \\
\hline Encyonema sp5 & & 6 & 1 & 1 & 1 & 2 & 2 & & 1 & & \\
\hline \multicolumn{12}{|l|}{ Encyonema minuta } \\
\hline \multicolumn{12}{|l|}{ Encyonema silicum } \\
\hline Encyonopsis cesetii & 8 & 6 & 4 & 4 & 2 & 1 & & 1 & 1 & 1 & 5 \\
\hline Encyonopsis falaisensis & 1 & 4 & 8 & 6 & 2 & 1 & 8 & 6 & 4 & 3 & 1 \\
\hline Encyonopsis microcephala & 31 & 22 & 17 & 35 & 33 & 51 & 48 & 32 & 25 & 23 & 4 \\
\hline Fragillaria sp1 & 5 & 1 & 1 & & & & & 4 & 1 & 2 & 1 \\
\hline \multicolumn{12}{|l|}{ Frustrulia vulgaris } \\
\hline \multicolumn{12}{|l|}{ Gomphoneis sp1 } \\
\hline Hantzschia amphioxys & & & 4 & 2 & & & & & & & \\
\hline Lindavia michiganiana & 31 & 29 & 27 & 3 & 16 & 12 & 17 & 16 & 17 & 19 & 25 \\
\hline Mayamaea sp1 & & & 3 & 2 & & & & & & & \\
\hline
\end{tabular}




\begin{tabular}{|c|c|c|c|c|c|c|c|c|c|c|c|}
\hline \multirow{2}{*}{$\begin{array}{l}\text { Updated Species Name (Guiry and } \\
\text { Guiry, 2018) }\end{array}$} & \multicolumn{11}{|c|}{ Depth (cm) } \\
\hline & 36 & 37 & 38 & 39 & 40 & 41 & 42 & 43 & 44 & 45 & 46 \\
\hline Navicula antonii & 11 & & & 2 & 3 & 5 & 5 & 1 & 5 & 3 & 3 \\
\hline Navicula cryptocephala & 12 & 4 & 3 & 4 & 3 & 4 & 12 & 1 & 9 & 2 & 5 \\
\hline Navicula cryptotenella & 23 & 32 & 27 & 49 & 43 & 7 & 69 & 59 & 45 & 44 & 61 \\
\hline Navicula gomphonema & & & 2 & 6 & 7 & & 1 & 3 & 3 & 5 & 5 \\
\hline \multicolumn{12}{|l|}{ Nupela impexiformis } \\
\hline Navicula notha & 25 & 13 & 7 & 13 & 12 & 18 & 9 & 13 & 13 & 15 & 16 \\
\hline Navicula Radiosa & 3 & 2 & 3 & 2 & 1 & 1 & 2 & 5 & 2 & 3 & 4 \\
\hline Navicula schweigeri & 22 & 12 & 13 & 22 & 19 & 2 & 8 & 5 & & 5 & 6 \\
\hline Navicula wildii & 12 & 4 & 13 & 13 & 6 & 5 & 3 & 3 & 7 & 1 & 1 \\
\hline Navicula sp4 & & 1 & & & & 1 & 2 & 2 & 1 & & 2 \\
\hline Navicula sp8 & 8 & 16 & 2 & 3 & 3 & 1 & 3 & 5 & & 3 & 3 \\
\hline Navicula sp9 & 12 & 13 & 4 & 2 & & & & & & & \\
\hline \multicolumn{12}{|l|}{ Navicula sp 10} \\
\hline Navicula sp12 & & & 1 & & & & & & & & \\
\hline Navicula sp13 & 1 & & & & & 1 & 1 & 1 & 2 & 2 & 3 \\
\hline Navicula sp14 & & 1 & 3 & 2 & & & 1 & 8 & 1 & 1 & \\
\hline Neidium afinne & & 1 & & & & & & & & 1 & 1 \\
\hline Neidium sp2 & 9 & 5 & 12 & 1 & 3 & 2 & 6 & 2 & 3 & 1 & 6 \\
\hline Nitzschia amphibia & 3 & 2 & & & & & & & 2 & & \\
\hline Nitzschia minuta & 22 & 7 & & & & & & 3 & 2 & 2 & 2 \\
\hline Nitzchia palacea & & & & & & & & 1 & & 1 & 1 \\
\hline Nitzschia palea sensu lato & 88 & 81 & 46 & 87 & 78 & 65 & 1 & 98 & 98 & 131 & 144 \\
\hline Nitzschia recta & 2 & 9 & 2 & 2 & 2 & 1 & & & & & \\
\hline \multicolumn{12}{|l|}{ Nitzschia sp6 } \\
\hline Pinnularia biceps (var 1) & 8 & 3 & 5 & 4 & 1 & 1 & 2 & 3 & 1 & 2 & 5 \\
\hline Pinnularia biceps (var 2) & & & & & 1 & & & & & & \\
\hline \multicolumn{12}{|l|}{ Pinnularia sp4 } \\
\hline \multicolumn{12}{|l|}{ Pinnularia sp5 } \\
\hline \multicolumn{12}{|l|}{ Pinnularia sp6 } \\
\hline \multicolumn{12}{|l|}{ Psamnothidium sp1 } \\
\hline Pseudostaurosira brevistriata & 4 & & & 6 & 9 & & & 2 & 2 & 1 & 5 \\
\hline Rhopalodia gibba & & & & & & & 1 & & 1 & & \\
\hline Rossitidium petersonii & 5 & & 3 & 2 & & 1 & & & 2 & 3 & 4 \\
\hline Sellaphora capitata & & & & & & 2 & 2 & 2 & & 1 & 2 \\
\hline Sellaphora pupula & 1 & 18 & 4 & 14 & 16 & 13 & 19 & 8 & 1 & 13 & 19 \\
\hline
\end{tabular}




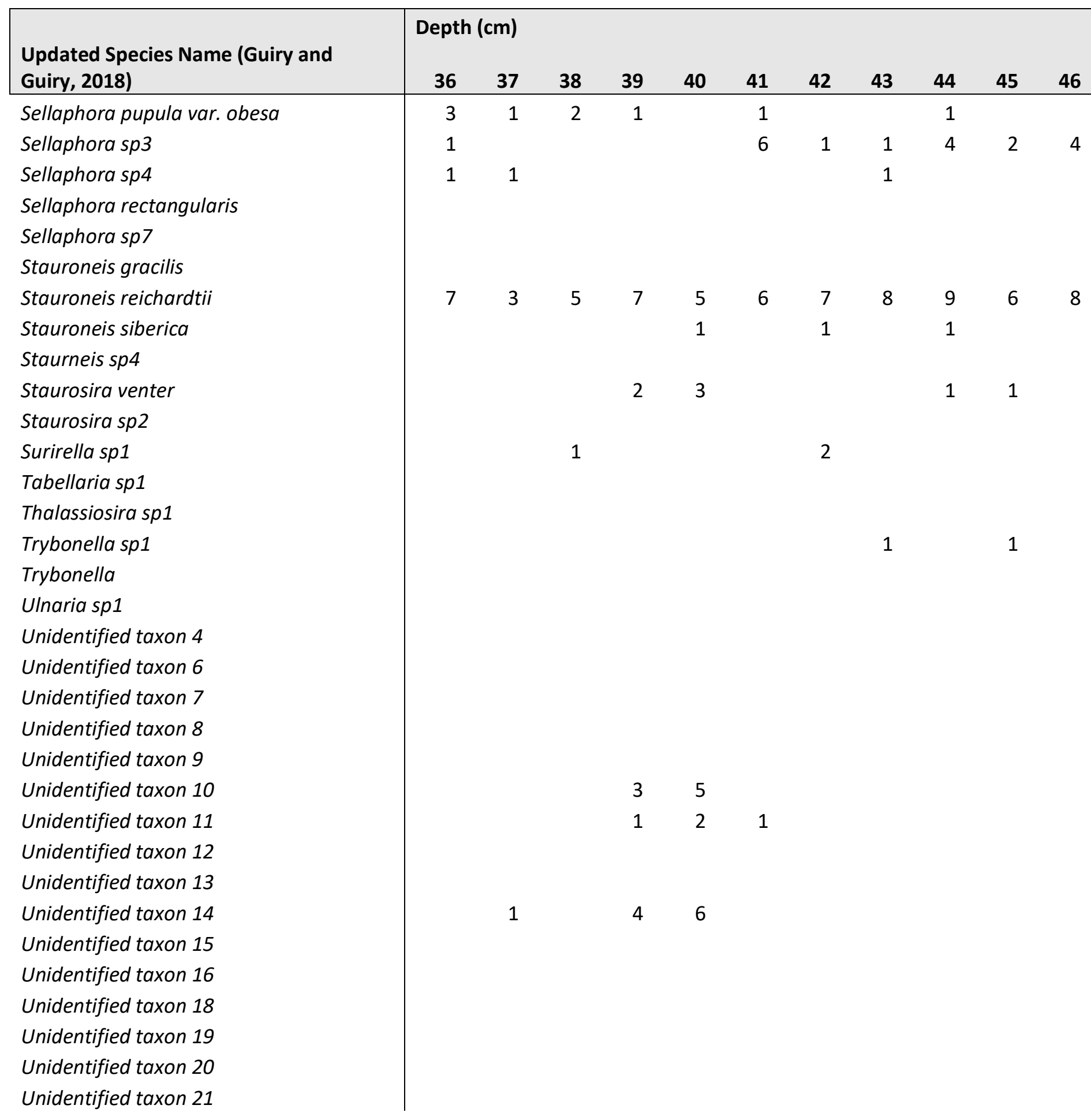




\begin{tabular}{|c|c|c|c|c|c|c|c|c|c|c|c|c|}
\hline $\begin{array}{l}\text { Updated Species Name (Guiry and } \\
\text { Guiry, 2018) }\end{array}$ & \multicolumn{12}{|c|}{$\begin{array}{l}\text { Depth } \\
\text { (cm) }\end{array}$} \\
\hline Achnanthidium atomus & 32 & 27 & 22 & 14 & 26 & 41 & 28 & 41 & 24 & 27 & 42 & 6 \\
\hline Achnanthidium minutissimum & 8 & 12 & 18 & 22 & 7 & 21 & 15 & 47 & 35 & 25 & 63 & 35 \\
\hline Achnanthidium sp6 & & 2 & 1 & & & & & & & & & \\
\hline Achnanthidium sp7 & & & & & & & & & & & & \\
\hline Amphora ovalis & & 1 & & & & & 3 & & & & & \\
\hline Aneumastus sp1 & & & & & & & & & & & & \\
\hline Brachysira microcephala & 58 & 6 & 73 & 75 & 64 & 75 & 42 & 91 & 88 & 82 & 88 & 53 \\
\hline Cyclostephanos invisitatus & 1 & 2 & 1 & 1 & 1 & & 11 & 3 & 6 & 6 & 9 & 5 \\
\hline Cyclotella distinguenda & & & & 1 & & 7 & 5 & 11 & 1 & 23 & 1 & 13 \\
\hline Cyclotella intermedia & 14 & 1 & & & & & & & & & & \\
\hline Cyclotella sp6 & & & & & & 2 & & 6 & & 5 & 2 & \\
\hline Cymbella sp1 & & 2 & 2 & 3 & 3 & & & & & & & \\
\hline Cymbopleura angustata & 1 & 2 & 2 & 2 & 1 & & & 2 & & 2 & 1 & \\
\hline Cymbopleura ehrenbergii & 7 & 2 & 4 & 6 & 13 & & & & & & & \\
\hline Cymbopleura sp2 & & 1 & 1 & 1 & 1 & & & & & & & \\
\hline Denticula elegans & 1 & & 1 & 2 & 3 & 2 & 2 & 4 & 6 & 3 & 5 & 7 \\
\hline Dipuneis occulata & & & & & 1 & & & & & & & \\
\hline Discostella pseudostelligera & 4 & 2 & 3 & 4 & 5 & 12 & 1 & 11 & 13 & 25 & 16 & 15 \\
\hline Discostella stelligera & 1 & 1 & 5 & 8 & 6 & 3 & 2 & 3 & 1 & 3 & 14 & 2 \\
\hline Encyonema cesatii sensu strata & 4 & 4 & 2 & & 5 & 7 & 4 & 2 & 1 & 4 & 2 & 5 \\
\hline Encyonema elginese & & & & & & & & & & & & \\
\hline Encyonema silesiacum & & 4 & 2 & & & 2 & 14 & 1 & 1 & 1 & 2 & 2 \\
\hline Encyonema sp3 & & & & & & & 1 & 1 & & 1 & & \\
\hline Encyonema sp5 & 1 & & 1 & 2 & 5 & 3 & 8 & 2 & 15 & 9 & 6 & 1 \\
\hline Encyonema minuta & & & & & & & & & & & & \\
\hline Encyonema silicum & & 1 & & & & & & & & & & \\
\hline Encyonopsis cesetii & 7 & & & & 3 & 7 & 2 & 4 & 1 & 1 & 3 & 8 \\
\hline Encyonopsis falaisensis & & & 1 & 2 & 4 & 1 & 5 & 19 & 17 & 14 & 5 & 7 \\
\hline Encyonopsis microcephala & 37 & 27 & 24 & 18 & 32 & 53 & 15 & 68 & 75 & 61 & 44 & 58 \\
\hline Fragillaria sp1 & & & 3 & 6 & 2 & & 1 & & & & & \\
\hline Frustrulia vulgaris & & & & & & & 2 & & & & & \\
\hline Gomphoneis sp1 & & & & & & & & & & & & \\
\hline Hantzschia amphioxys & & 1 & & & & & & 1 & 3 & 4 & & \\
\hline Lindavia michiganiana & 19 & 8 & 8 & 8 & 7 & 4 & 2 & 6 & 26 & 11 & 14 & 18 \\
\hline Mayamaea sp1 & & & & & & & & 1 & & & & 1 \\
\hline
\end{tabular}




\begin{tabular}{|c|c|c|c|c|c|c|c|c|c|c|c|c|}
\hline $\begin{array}{l}\text { Updated Species Name (Guiry and } \\
\text { Guiry, 2018) }\end{array}$ & $\begin{array}{c}\begin{array}{c}\text { Depth } \\
\text { (cm) }\end{array} \\
47\end{array}$ & 48 & 49 & 50 & 51 & 52 & 53 & 54 & 55 & 56 & 57 & 58 \\
\hline Navicula antonii & 2 & 12 & 9 & 6 & & 27 & 26 & 19 & 26 & 11 & 24 & 18 \\
\hline Navicula cryptocephala & 6 & 1 & 5 & 9 & 4 & 1 & & 6 & 2 & 3 & 5 & 4 \\
\hline Navicula cryptotenella & 47 & 57 & 48 & 32 & 28 & 2 & 15 & 17 & 11 & 25 & 27 & 27 \\
\hline Navicula gomphonema & 3 & 5 & 5 & 5 & 3 & 13 & 23 & 1 & 13 & 19 & 17 & 17 \\
\hline Nupela impexiformis & & & & & & 1 & & 1 & 1 & & 6 & 3 \\
\hline Navicula notha & 1 & 7 & 9 & 1 & 8 & 1 & 12 & 12 & 5 & 5 & 1 & 1 \\
\hline Navicula Radiosa & 4 & 1 & & & 3 & 1 & 6 & & & 7 & & 3 \\
\hline Navicula schweigeri & 5 & 8 & 9 & 9 & 23 & & & 2 & & 2 & 1 & \\
\hline Navicula wildii & 1 & 9 & 7 & 5 & 3 & 4 & 1 & 1 & 8 & 12 & 14 & 7 \\
\hline Navicula sp4 & 3 & 1 & 1 & 2 & & & 2 & 1 & 1 & 2 & 1 & 2 \\
\hline Navicula sp8 & 2 & & 2 & 4 & 5 & 22 & 2 & 22 & 24 & 18 & 17 & 2 \\
\hline \multicolumn{13}{|l|}{ Navicula spg } \\
\hline \multicolumn{13}{|l|}{ Navicula sp 10} \\
\hline Navicula sp12 & & & & 1 & & 1 & 2 & 3 & 4 & 3 & 3 & \\
\hline Navicula sp13 & 3 & & & 1 & & & & & & & & \\
\hline \multicolumn{13}{|l|}{ Navicula sp14 } \\
\hline Neidium afinne & 1 & & & & 1 & 4 & 1 & 4 & 2 & 2 & 2 & 3 \\
\hline Neidium sp2 & 8 & 6 & 5 & 5 & 9 & 5 & 16 & 3 & 2 & & & 3 \\
\hline Nitzschia amphibia & & 1 & & & & & & & 3 & & 4 & \\
\hline Nitzschia minuta & 2 & 2 & 2 & 3 & & & & & & & & \\
\hline Nitzchia palacea & 1 & & & 1 & & 2 & & 4 & 2 & 7 & & 5 \\
\hline Nitzschia palea sensu lato & 83 & 95 & 97 & 85 & 84 & 118 & 89 & 118 & 122 & 155 & 144 & 154 \\
\hline Nitzschia recta & & & & & & & & & & & & 2 \\
\hline Nitzschia sp6 & & & & & & & & & & & & \\
\hline Pinnularia biceps (var 1) & 6 & 8 & 15 & 21 & 18 & 23 & 9 & 21 & 14 & 4 & 15 & 2 \\
\hline Pinnularia biceps (var 2) & & & & & & & & & & & 6 & 3 \\
\hline \multicolumn{13}{|l|}{ Pinnularia sp4 } \\
\hline \multicolumn{13}{|l|}{ Pinnularia sp5 } \\
\hline \multicolumn{13}{|l|}{ Pinnularia sp6 } \\
\hline Psamnothidium sp1 & & & & & & & & & & 1 & 1 & \\
\hline Pseudostaurosira brevistriata & 7 & & 1 & 2 & 2 & 1 & 8 & 3 & 2 & 3 & 3 & 5 \\
\hline Rhopalodia gibba & 1 & 3 & 1 & & & & & & & & 8 & \\
\hline Rossitidium petersonii & 4 & 1 & 2 & 3 & & 4 & 2 & 6 & 4 & 8 & & \\
\hline Sellaphora capitata & 3 & 1 & & & & & & & & & & \\
\hline Sellaphora pupula & 16 & 25 & 17 & 7 & 23 & 32 & 58 & 32 & 32 & 19 & 24 & 24 \\
\hline
\end{tabular}




\begin{tabular}{|c|c|c|c|c|c|c|c|c|c|c|c|c|}
\hline $\begin{array}{l}\text { Updated Species Name (Guiry and } \\
\text { Guiry, 2018) }\end{array}$ & $\begin{array}{c}\begin{array}{c}\text { Dept } \\
\text { (cm) }\end{array} \\
47\end{array}$ & 48 & 49 & 50 & 51 & 52 & 53 & 54 & 55 & 56 & 57 & 58 \\
\hline Sellaphora pupula var. obesa & & 1 & 2 & 4 & 4 & & & 5 & & & & \\
\hline Sellaphora sp3 & 4 & 5 & 4 & 3 & 2 & & & & & & & \\
\hline Sellaphora sp4 & 1 & & 1 & 2 & & & & & & & & \\
\hline Sellaphora rectangularis & & & & & & & & & & & & \\
\hline Sellaphora sp7 & & & & & & & & & & & & \\
\hline Stauroneis gracilis & & & & & & & & & & & & \\
\hline Stauroneis reichardtii & 7 & 16 & 14 & 1 & 17 & 26 & 48 & & 8 & 2 & 6 & 5 \\
\hline Stauroneis siberica & & 4 & 2 & & & 13 & 2 & & 4 & 5 & 4 & 4 \\
\hline Staurneis sp4 & & & & & & & & & & & & \\
\hline Staurosira venter & & & & & & & & & & & & \\
\hline Staurosira sp2 & & & & & 4 & & & & & & & \\
\hline Surirella sp1 & & & & & & & & & & & & \\
\hline Tabellaria sp1 & & & & & & & & & & & & \\
\hline Thalassiosira sp1 & & & & & & & & & & & & \\
\hline Trybonella sp1 & & & & & & 1 & & & & 2 & & \\
\hline Trybonella & & & & & & & & & & & & \\
\hline Ulnaria sp1 & & 1 & & & & & & & & 1 & & \\
\hline Unidentified taxon 4 & & & & & & & 1 & & & & 3 & \\
\hline Unidentified taxon 6 & & & & & & 1 & 1 & & 1 & 2 & & \\
\hline Unidentified taxon 7 & & & & & & & 1 & 1 & & 1 & & \\
\hline Unidentified taxon 8 & & & & & & & & & & 1 & & \\
\hline Unidentified taxon 9 & & & & & & & & & & & & \\
\hline Unidentified taxon 10 & & & & & & 4 & & & & & & \\
\hline Unidentified taxon 11 & & & & & & & & & & & & \\
\hline Unidentified taxon 12 & & & & & & & & & & & & \\
\hline Unidentified taxon 13 & & & & & & & & & & & & \\
\hline Unidentified taxon 14 & & & & & & & & & & & & \\
\hline Unidentified taxon 15 & & & & & & & & & & & & \\
\hline Unidentified taxon 16 & & & & & & & & & & & & \\
\hline Unidentified taxon 18 & & & & & & & & & & & & \\
\hline Unidentified taxon 19 & & & & & & & & & & & & \\
\hline Unidentified taxon 20 & & & & & & & & & & & & \\
\hline Unidentified taxon 21 & & & & & & & & & & & & \\
\hline
\end{tabular}




\begin{tabular}{|c|c|c|c|c|c|c|c|c|c|c|c|}
\hline \multirow{2}{*}{$\begin{array}{l}\text { Updated Species Name (Guiry and } \\
\text { Guiry, 2018) }\end{array}$} & \multicolumn{11}{|c|}{ Depth (cm) } \\
\hline & 59 & 60 & 61 & 62 & 63 & 64 & 65 & 66 & 67 & 68 & 69 \\
\hline Achnanthidium atomus & 57 & 45 & 38 & 39 & 56 & 21 & 18 & 7 & 16 & 8 & 2 \\
\hline Achnanthidium minutissimum & 5 & 11 & 18 & 26 & 22 & 1 & 12 & 7 & 14 & 6 & 13 \\
\hline Achnanthidium sp6 & & & & & 5 & & & & & & \\
\hline \multicolumn{12}{|l|}{ Achnanthidium sp7 } \\
\hline Amphora ovalis & & & & 1 & & & & & & & \\
\hline Aneumastus sp1 & & & & & 2 & & & & & & \\
\hline Brachysira microcephala & 86 & 61 & 19 & 78 & 26 & 3 & 34 & 19 & 51 & 28 & 42 \\
\hline Cyclostephanos invisitatus & 15 & 6 & & & 9 & & & & 2 & 2 & 4 \\
\hline Cyclotella distinguenda & 27 & 18 & 5 & 1 & 11 & 1 & 4 & 4 & 4 & & 3 \\
\hline \multicolumn{12}{|l|}{ Cyclotella intermedia } \\
\hline Cyclotella sp6 & & & & 1 & 5 & & & & & & \\
\hline Cymbella sp1 & & & & & 1 & 5 & 4 & 1 & 3 & 2 & 2 \\
\hline Cymbopleura angustata & & & 5 & 3 & 7 & 7 & 5 & 1 & 2 & 1 & 2 \\
\hline Cymbopleura ehrenbergii & & & & & & 1 & 1 & 1 & 3 & 2 & 2 \\
\hline Cymbopleura sp2 & & & & & 3 & & & & 1 & 1 & \\
\hline Denticula elegans & 2 & 12 & 5 & 7 & 8 & & & & 2 & 2 & 1 \\
\hline Dipuneis occulata & & & & & & & & & 3 & 3 & 2 \\
\hline Discostella pseudostelligera & 16 & 14 & 11 & 9 & 1 & 1 & & & & & \\
\hline Discostella stelligera & & & & & 2 & 2 & 3 & 3 & 2 & & 1 \\
\hline Encyonema cesatii sensu strata & 5 & 4 & 1 & 4 & 4 & & 2 & 3 & 2 & & 4 \\
\hline Encyonema elginese & & & & & 3 & & & & & & \\
\hline Encyonema silesiacum & & 4 & 2 & 2 & 2 & 2 & 1 & & & & \\
\hline Encyonema sp3 & 3 & 6 & & & 2 & 5 & 8 & 6 & 6 & 1 & 5 \\
\hline Encyonema sp5 & 2 & 6 & 11 & 4 & & & & & 2 & 2 & 1 \\
\hline \multicolumn{12}{|l|}{ Encyonema minuta } \\
\hline \multicolumn{12}{|l|}{ Encyonema silicum } \\
\hline Encyonopsis cesetii & 3 & & & 1 & & 2 & 1 & & 2 & 2 & 2 \\
\hline Encyonopsis falaisensis & 19 & 11 & 6 & & 17 & & 2 & 3 & 7 & 4 & 6 \\
\hline Encyonopsis microcephala & 51 & 46 & 58 & 44 & 24 & 16 & 17 & 9 & 24 & 13 & 28 \\
\hline Fragillaria sp1 & & & & & 5 & 5 & 5 & 3 & 2 & & 1 \\
\hline Frustrulia vulgaris & 1 & & 1 & & 2 & & & & & & \\
\hline Gomphoneis sp1 & & & & & & & & & 1 & 1 & \\
\hline Hantzschia amphioxys & & & 2 & & & & & & & & \\
\hline Lindavia michiganiana & 15 & 14 & 3 & 2 & 14 & 18 & 15 & 6 & 9 & 3 & 6 \\
\hline Mayamaea sp1 & 1 & & & & & & & & & & \\
\hline
\end{tabular}




\begin{tabular}{|c|c|c|c|c|c|c|c|c|c|c|c|}
\hline \multirow{2}{*}{$\begin{array}{l}\text { Updated Species Name (Guiry and } \\
\text { Guiry, 2018) }\end{array}$} & \multicolumn{11}{|c|}{ Depth (cm) } \\
\hline & 59 & 60 & 61 & 62 & 63 & 64 & 65 & 66 & 67 & 68 & 69 \\
\hline Navicula antonii & 29 & 11 & 31 & 36 & 17 & 7 & 1 & 7 & 1 & 3 & 6 \\
\hline Navicula cryptocephala & 1 & & & & 2 & 2 & 6 & 6 & 6 & 1 & 5 \\
\hline Navicula cryptotenella & 37 & 23 & 5 & 43 & 23 & 19 & 24 & 15 & 4 & 22 & 48 \\
\hline Navicula gomphonema & 25 & 29 & 16 & 21 & 9 & & & & & & \\
\hline Nupela impexiformis & 3 & 4 & & & 18 & & & & & & \\
\hline Navicula notha & 17 & 1 & 3 & 19 & 27 & 17 & 19 & 1 & 18 & 7 & 13 \\
\hline Navicula Radiosa & 3 & & 4 & 2 & & & & & 4 & 4 & 3 \\
\hline Navicula schweigeri & & 3 & 1 & 2 & 13 & 12 & 2 & 15 & 2 & 5 & 15 \\
\hline Navicula wildii & 5 & 4 & 1 & 3 & 1 & 1 & 7 & 1 & 9 & 7 & 8 \\
\hline Navicula sp4 & 5 & 3 & 3 & 1 & 1 & 5 & 5 & 3 & 2 & & 2 \\
\hline Navicula sp8 & 6 & 15 & 2 & 3 & 6 & 6 & 8 & 6 & 8 & 2 & 6 \\
\hline \multicolumn{12}{|l|}{ Navicula sp9 } \\
\hline \multicolumn{12}{|l|}{ Navicula sp 10} \\
\hline Navicula sp12 & & & 1 & 3 & & & & & & & \\
\hline Navicula sp13 & & & & & & & 1 & 1 & 1 & & \\
\hline \multicolumn{12}{|l|}{ Navicula sp14 } \\
\hline Neidium afinne & 7 & 3 & 6 & 4 & 4 & 6 & 4 & 1 & 1 & & 2 \\
\hline Neidium sp2 & 2 & 5 & 3 & 2 & & & 1 & 1 & 1 & & 1 \\
\hline Nitzschia amphibia & 2 & & & 2 & & & & & & & \\
\hline Nitzschia minuta & & & & & & 8 & 12 & 9 & 8 & & 7 \\
\hline Nitzchia palacea & & 15 & 3 & 1 & 1 & & 2 & 3 & 2 & & 2 \\
\hline Nitzschia palea sensu lato & 155 & 13 & 175 & 182 & 148 & 155 & 168 & 88 & 172 & 74 & 178 \\
\hline Nitzschia recta & & & & & & & & & 2 & 2 & 1 \\
\hline Nitzschia sp6 & & & & & 8 & & & & & & \\
\hline Pinnularia biceps (var 1) & 19 & 14 & 1 & 16 & 11 & 14 & 12 & 4 & 1 & 5 & 13 \\
\hline Pinnularia biceps (var 2) & & & & & 4 & & & & & & \\
\hline \multicolumn{12}{|l|}{ Pinnularia sp4 } \\
\hline \multicolumn{12}{|l|}{ Pinnularia sp5 } \\
\hline \multicolumn{12}{|l|}{ Pinnularia sp6 } \\
\hline \multicolumn{12}{|l|}{ Psamnothidium sp1 } \\
\hline Pseudostaurosira brevistriata & 12 & 26 & 5 & 11 & 11 & & & & & & \\
\hline \multicolumn{12}{|l|}{ Rhopalodia gibba } \\
\hline Rossitidium petersonii & & & 2 & 2 & 5 & 5 & 4 & 1 & 1 & & 1 \\
\hline \multicolumn{12}{|l|}{ Sellaphora capitata } \\
\hline Sellaphora pupula & 27 & 41 & 2 & 16 & 24 & 35 & 3 & 12 & 19 & 7 & 22 \\
\hline
\end{tabular}




\begin{tabular}{|c|c|c|c|c|c|c|c|c|c|c|c|}
\hline $\begin{array}{l}\text { Updated Species Name (Guiry and } \\
\text { Guiry, 2018) }\end{array}$ & $\begin{array}{r}\text { Deptr } \\
59 \\
\end{array}$ & $\mathrm{~cm})$ & 61 & 62 & 63 & 64 & 65 & 66 & 67 & 68 & 69 \\
\hline Sellaphora pupula var. obesa & & & & & 4 & 4 & 5 & 3 & 7 & 4 & 5 \\
\hline Sellaphora sp3 & & & & & 4 & 4 & 11 & 1 & 12 & 2 & 9 \\
\hline Sellaphora sp4 & & & & & 3 & 3 & 1 & & & & \\
\hline Sellaphora rectangularis & & & & & & & & & & & \\
\hline Sellaphora sp7 & & & & & & & & & & & \\
\hline Stauroneis gracilis & & & & & & 1 & & & & & \\
\hline Stauroneis reichardtii & 7 & 9 & 13 & 4 & 5 & 6 & 8 & 6 & 14 & 7 & 12 \\
\hline Stauroneis siberica & & & 4 & 4 & 4 & 4 & 3 & 1 & 2 & 1 & 2 \\
\hline Staurneis sp4 & & & & & 1 & 1 & & & & & \\
\hline Staurosira venter & & & & & & & & & & & \\
\hline Staurosira sp2 & & & & & 1 & & & & & & \\
\hline Surirella sp1 & & & & & & & & & & & \\
\hline Tabellaria sp1 & & & & & & & & & & & \\
\hline Thalassiosira sp1 & & & & & & & & & & & \\
\hline Trybonella sp1 & & & & & & & & & & & \\
\hline Trybonella & & & & & & & & & & & \\
\hline Ulnaria sp1 & & & & & & & & & & & \\
\hline Unidentified taxon 4 & 1 & & & & & & & & & & \\
\hline Unidentified taxon 6 & & & & 2 & 1 & & & & & & \\
\hline Unidentified taxon 7 & & & 2 & & & & & & & & \\
\hline Unidentified taxon 8 & & & & & & & & & & & \\
\hline Unidentified taxon 9 & & & & & & & & & & & \\
\hline Unidentified taxon 10 & & & & & 9 & & & & & & \\
\hline Unidentified taxon 11 & & & & & & & & & & & \\
\hline Unidentified taxon 12 & & & & & & & & & & & \\
\hline Unidentified taxon 13 & & & & & & & & & & & \\
\hline Unidentified taxon 14 & & & & & & 1 & & & & & \\
\hline Unidentified taxon 15 & & & & & 1 & & & & & & \\
\hline Unidentified taxon 16 & & & & & & & & & & & \\
\hline Unidentified taxon 18 & & & & & & & & & & & \\
\hline Unidentified taxon 19 & & & & & & & & & & & \\
\hline Unidentified taxon 20 & & & & & & & & & & & \\
\hline Unidentified taxon 21 & & & & & 2 & & & & & & \\
\hline
\end{tabular}




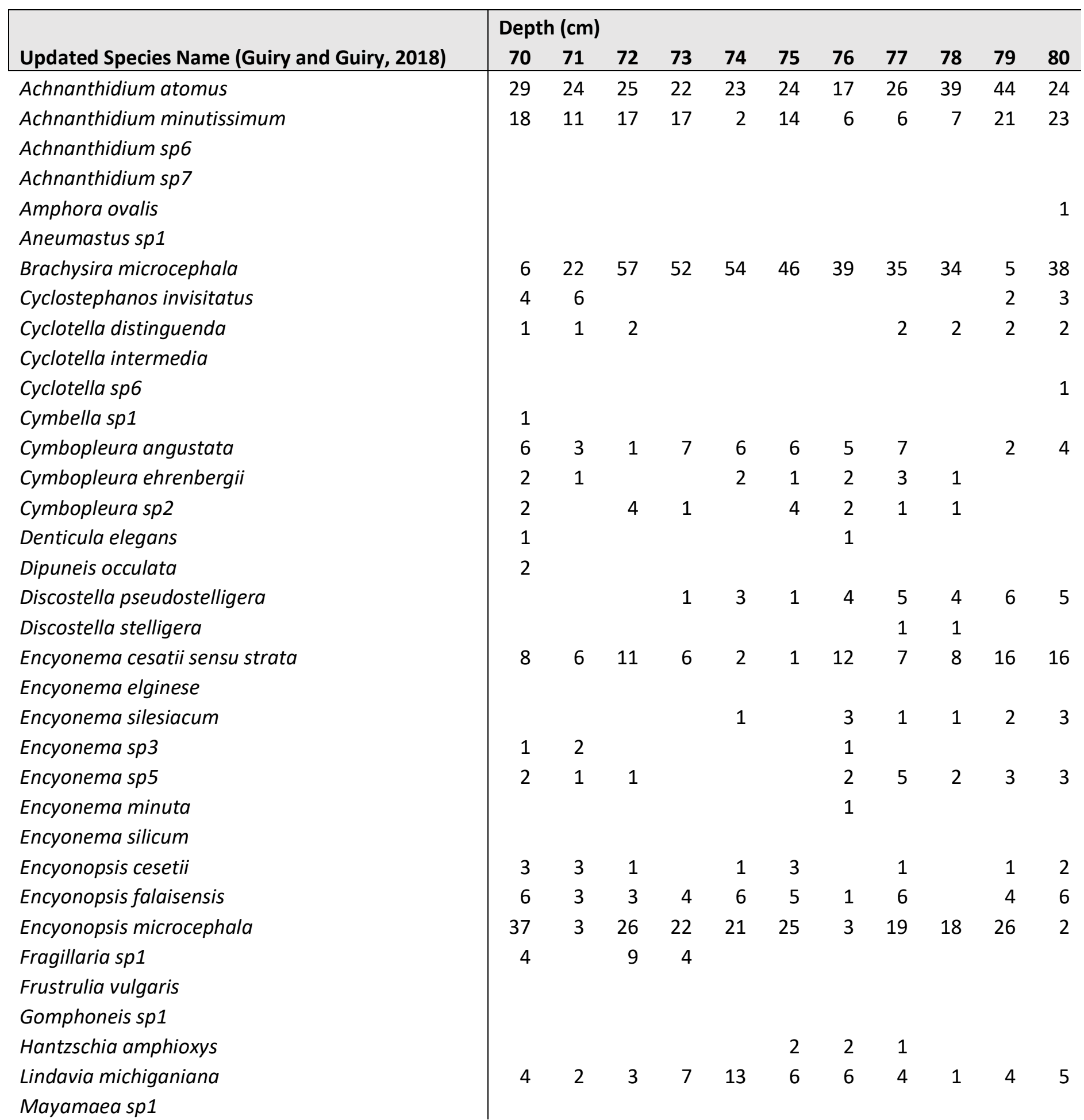




\begin{tabular}{|c|c|c|c|c|c|c|c|c|c|c|c|}
\hline Updated Species Name (Guiry and Guiry, 2018) & 70 & 71 & 72 & 73 & 74 & 75 & 76 & 77 & 78 & 79 & 80 \\
\hline Navicula antonii & 5 & & 7 & 3 & & 3 & & 1 & 3 & 2 & 1 \\
\hline Navicula cryptocephala & 6 & 3 & 8 & 7 & 7 & 1 & 7 & 4 & 8 & 5 & \\
\hline Navicula cryptotenella & 62 & 54 & 39 & 44 & 56 & 55 & 56 & 54 & 45 & 56 & 35 \\
\hline Navicula gomphonema & 5 & & 11 & 5 & & 2 & & 3 & & & \\
\hline \multicolumn{12}{|l|}{ Nupela impexiformis } \\
\hline Navicula notha & 12 & 4 & 11 & 11 & 13 & 7 & 13 & 17 & 9 & 14 & 12 \\
\hline Navicula Radiosa & 3 & 1 & & & 2 & 3 & 2 & & 1 & & \\
\hline Navicula schweigeri & 8 & 6 & 4 & 8 & 14 & 2 & 14 & 19 & 7 & 8 & 5 \\
\hline Navicula wildii & 1 & 5 & 4 & 3 & 3 & 11 & 3 & 6 & 1 & 4 & 6 \\
\hline Navicula sp4 & & 1 & & & & 1 & & 1 & 2 & 2 & 1 \\
\hline Navicula sp8 & 6 & 2 & 8 & 4 & 1 & 6 & 1 & 4 & 4 & 2 & \\
\hline \multicolumn{12}{|l|}{ Navicula sp9 } \\
\hline \multicolumn{12}{|l|}{ Navicula sp 10} \\
\hline \multicolumn{12}{|l|}{ Navicula sp12 } \\
\hline Navicula sp13 & & & & 1 & 3 & & 3 & & & & 1 \\
\hline \multicolumn{12}{|l|}{ Navicula sp14 } \\
\hline Neidium afinne & 2 & 3 & 2 & & & 1 & & 2 & & & 1 \\
\hline Neidium sp2 & 1 & 1 & 2 & & & 6 & & 3 & 3 & 3 & 2 \\
\hline Nitzschia amphibia & & & & & 1 & & 1 & & & & \\
\hline Nitzschia minuta & 3 & 4 & 3 & 3 & 4 & & 4 & 2 & 2 & 4 & 5 \\
\hline Nitzchia palacea & & 1 & 1 & & & 2 & & 2 & 3 & 4 & 3 \\
\hline Nitzschia palea sensu lato & 185 & 159 & 13 & 11 & 13 & 125 & 13 & 147 & 121 & 167 & 117 \\
\hline Nitzschia recta & 1 & & & & & & & & & & \\
\hline \multicolumn{12}{|l|}{ Nitzschia sp6 } \\
\hline Pinnularia biceps (var 1) & 17 & 16 & 13 & 8 & 5 & 22 & 5 & 7 & 9 & 9 & 5 \\
\hline Pinnularia biceps (var 2) & & & 1 & & & & & & 1 & 7 & 1 \\
\hline \multicolumn{12}{|l|}{ Pinnularia sp4 } \\
\hline \multicolumn{12}{|l|}{ Pinnularia sp5 } \\
\hline \multicolumn{12}{|l|}{ Pinnularia sp6 } \\
\hline \multicolumn{12}{|l|}{ Psamnothidium sp1 } \\
\hline Pseudostaurosira brevistriata & & & 1 & & & 7 & & 1 & 2 & 2 & 1 \\
\hline Rhopalodia gibba & & & & & 1 & & 1 & & & & \\
\hline Rossitidium petersonii & & 1 & & & & 3 & & & 3 & 2 & \\
\hline \multicolumn{12}{|l|}{ Sellaphora capitata } \\
\hline Sellaphora pupula & 23 & 23 & 14 & 15 & 18 & 25 & 18 & 2 & 35 & 4 & 23 \\
\hline
\end{tabular}




\begin{tabular}{|c|c|c|c|c|c|c|c|c|c|c|c|}
\hline \multirow[b]{2}{*}{ Updated Species Name (Guiry and Guiry, 2018) } & \multicolumn{11}{|c|}{ Depth (cm) } \\
\hline & 70 & 71 & 72 & 73 & 74 & 75 & 76 & 77 & 78 & 79 & 80 \\
\hline Sellaphora pupula var. obesa & 4 & 2 & & & 2 & & 2 & 4 & & 2 & 3 \\
\hline Sellaphora sp3 & 6 & 4 & 6 & 8 & 13 & 5 & 13 & 4 & 11 & 9 & 3 \\
\hline \multicolumn{12}{|l|}{ Sellaphora sp4 } \\
\hline \multicolumn{12}{|l|}{ Sellaphora rectangularis } \\
\hline \multicolumn{12}{|l|}{ Sellaphora sp7 } \\
\hline \multicolumn{12}{|l|}{ Stauroneis gracilis } \\
\hline Stauroneis reichardtii & 12 & 9 & 6 & 4 & 3 & 11 & & 8 & 17 & 18 & 1 \\
\hline Stauroneis siberica & 3 & 1 & 4 & 2 & 2 & 9 & 2 & 2 & 4 & 4 & 2 \\
\hline \multicolumn{12}{|l|}{ Staurneis sp4 } \\
\hline Staurosira venter & & & & & & & & & 1 & 1 & 1 \\
\hline \multicolumn{12}{|l|}{ Staurosira sp2 } \\
\hline Surirella sp1 & & & 1 & & & & & & & & \\
\hline \multicolumn{12}{|l|}{ Tabellaria sp1 } \\
\hline \multicolumn{12}{|l|}{ Thalassiosira sp1 } \\
\hline \multicolumn{12}{|l|}{ Trybonella sp1 } \\
\hline \multicolumn{12}{|l|}{ Trybonella } \\
\hline \multicolumn{12}{|l|}{ Ulnaria sp1 } \\
\hline \multicolumn{12}{|l|}{ Unidentified taxon 4} \\
\hline \multicolumn{12}{|l|}{ Unidentified taxon 6} \\
\hline \multicolumn{12}{|l|}{ Unidentified taxon 7} \\
\hline \multicolumn{12}{|l|}{ Unidentified taxon 8} \\
\hline \multicolumn{12}{|l|}{ Unidentified taxon 9} \\
\hline \multicolumn{12}{|l|}{ Unidentified taxon 10} \\
\hline Unidentified taxon 11 & & & 1 & & & & & & & & \\
\hline \multicolumn{12}{|l|}{ Unidentified taxon 12} \\
\hline \multicolumn{12}{|l|}{ Unidentified taxon 13} \\
\hline Unidentified taxon 14 & & & & & 2 & & & & 2 & 1 & \\
\hline \multicolumn{12}{|l|}{ Unidentified taxon 15} \\
\hline \multicolumn{12}{|l|}{ Unidentified taxon 16} \\
\hline \multicolumn{12}{|l|}{ Unidentified taxon 18} \\
\hline \multicolumn{12}{|l|}{ Unidentified taxon 19} \\
\hline \multicolumn{12}{|l|}{ Unidentified taxon 20} \\
\hline Unidentified taxon 21 & & & & & & & & & & & \\
\hline
\end{tabular}




\begin{tabular}{|c|c|c|c|c|c|c|c|c|c|c|c|c|}
\hline \multirow[b]{2}{*}{ Updated Species Name (Guiry and Guiry, 2018) } & \multicolumn{12}{|c|}{ Depth (cm) } \\
\hline & 81 & 82 & 83 & 84 & 85 & 86 & 87 & 88 & 89 & 90 & 91 & 92 \\
\hline Achnanthidium atomus & 36 & 25 & 16 & 28 & 37 & 19 & 27 & 35 & 14 & 25 & 27 & 34 \\
\hline Achnanthidium minutissimum & 2 & 18 & 12 & 2 & 19 & 1 & 13 & 19 & 5 & 9 & 1 & 29 \\
\hline \multicolumn{13}{|l|}{ Achnanthidium sp6 } \\
\hline \multicolumn{13}{|l|}{ Achnanthidium sp7 } \\
\hline \multicolumn{13}{|l|}{ Amphora ovalis } \\
\hline \multicolumn{13}{|l|}{ Aneumastus sp1 } \\
\hline Brachysira microcephala & 45 & 31 & 24 & 36 & 41 & 17 & 33 & 33 & 16 & 32 & 38 & 17 \\
\hline Cyclostephanos invisitatus & 1 & 2 & & 2 & 3 & 2 & 1 & 2 & 2 & 1 & & \\
\hline Cyclotella distinguenda & 1 & & & & & & & & 1 & & & 1 \\
\hline Cyclotella intermedia & & 1 & & 1 & 1 & 2 & & 1 & & & & \\
\hline \multicolumn{13}{|l|}{ Cyclotella sp6 } \\
\hline Cymbella sp1 & 2 & 6 & 4 & 7 & 13 & 8 & 7 & 7 & 5 & 4 & & 1 \\
\hline Cymbopleura angustata & 3 & 5 & 3 & 6 & 6 & 5 & 4 & 7 & 1 & 2 & 4 & 9 \\
\hline Cymbopleura ehrenbergii & 2 & 1 & 3 & 2 & 4 & 1 & 2 & 2 & 2 & 2 & 2 & 1 \\
\hline Cymbopleura sp2 & 2 & 2 & 3 & 2 & 6 & 2 & 3 & 4 & 4 & 3 & & 3 \\
\hline Denticula elegans & & & & & & 1 & & 2 & & & & 5 \\
\hline Dipuneis occulata & & & & & & & 25 & 29 & & 48 & 11 & \\
\hline Discostella pseudostelligera & 3 & 1 & & 1 & & & & & & & & \\
\hline \multicolumn{13}{|l|}{ Discostella stelligera } \\
\hline Encyonema cesatii sensu strata & 1 & 6 & & 7 & 2 & 2 & 2 & 3 & 1 & 3 & 6 & \\
\hline \multicolumn{13}{|l|}{ Encyonema elginese } \\
\hline Encyonema silesiacum & 1 & 1 & & 1 & & 1 & & 1 & & & 2 & 1 \\
\hline Encyonema sp3 & & & & & 1 & & & 1 & 2 & 1 & & \\
\hline Encyonema sp5 & 2 & 3 & & 4 & 5 & 5 & 3 & 4 & 2 & 2 & 1 & 2 \\
\hline Encyonema minuta & & & & & & & & 1 & & & 1 & 3 \\
\hline \multicolumn{13}{|l|}{ Encyonema silicum } \\
\hline Encyonopsis cesetii & & & & & 1 & & & 1 & 2 & 1 & & 2 \\
\hline Encyonopsis falaisensis & 5 & 4 & 4 & 5 & 5 & 1 & 4 & 5 & 2 & 4 & 6 & 7 \\
\hline Encyonopsis microcephala & 22 & 21 & 1 & 24 & 28 & 19 & 21 & 25 & 8 & 17 & 22 & 18 \\
\hline \multicolumn{13}{|l|}{ Fragillaria sp1 } \\
\hline \multicolumn{13}{|l|}{ Frustrulia vulgaris } \\
\hline \multicolumn{13}{|l|}{ Gomphoneis sp1 } \\
\hline \multicolumn{13}{|l|}{ Hantzschia amphioxys } \\
\hline Lindavia michiganiana & 7 & 9 & 9 & 11 & 16 & 8 & 11 & 1 & 5 & 8 & 9 & 4 \\
\hline Mayamaea sp1 & 2 & 1 & 4 & 2 & 2 & & 1 & & & & & \\
\hline
\end{tabular}




\begin{tabular}{|c|c|c|c|c|c|c|c|c|c|c|c|c|}
\hline \multirow[b]{2}{*}{ Updated Species Name (Guiry and Guiry, 2018) } & \multicolumn{12}{|c|}{ Depth (cm) } \\
\hline & 81 & 82 & 83 & 84 & 85 & 86 & 87 & 88 & 89 & 90 & 91 & 92 \\
\hline Navicula antonii & 6 & 4 & 9 & 5 & 12 & 1 & 8 & 6 & 7 & 8 & 5 & 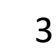 \\
\hline Navicula cryptocephala & 3 & 1 & & 1 & 4 & 2 & 3 & 6 & 3 & 4 & 3 & 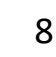 \\
\hline Navicula cryptotenella & 47 & 27 & 22 & 31 & 32 & 11 & 34 & 45 & 12 & 41 & 65 & 47 \\
\hline Navicula gomphonema & 2 & 1 & 4 & 2 & 6 & & 6 & 7 & 4 & 8 & 1 & 9 \\
\hline Nupela impexiformis & & 1 & 1 & 1 & 1 & 1 & & & & & & \\
\hline Navicula notha & 16 & 14 & 12 & 16 & 26 & 1 & 17 & 22 & 13 & 16 & 11 & 23 \\
\hline Navicula Radiosa & & 3 & & 3 & 5 & 6 & 5 & 7 & 1 & 5 & 1 & 3 \\
\hline Navicula schweigeri & 12 & 8 & 13 & 9 & 16 & 2 & 1 & 1 & 7 & 9 & 7 & 1 \\
\hline Navicula wildii & 3 & 3 & & 4 & 2 & 3 & 1 & 2 & & & 2 & \\
\hline Navicula sp4 & 3 & 1 & 3 & 1 & 1 & & 1 & & & & 1 & \\
\hline Navicula sp8 & 3 & 3 & 3 & 3 & 1 & 4 & 8 & 9 & 7 & 1 & 9 & \\
\hline Navicula sp9 & & & & & & & & & 1 & & & \\
\hline \multicolumn{13}{|l|}{ Navicula sp 10} \\
\hline Navicula sp12 & & 1 & & 1 & 2 & 2 & 1 & 1 & 1 & & & \\
\hline Navicula sp13 & & & & & & & & 1 & 1 & & & \\
\hline \multicolumn{13}{|l|}{ Navicula sp14 } \\
\hline Neidium afinne & 1 & 2 & 1 & 2 & 2 & 2 & 1 & 1 & & & & \\
\hline Neidium sp2 & 4 & 3 & 4 & 3 & 8 & 1 & 7 & 9 & 6 & 1 & 11 & \\
\hline Nitzschia amphibia & 1 & 1 & 3 & 1 & 1 & & 1 & & & & & \\
\hline Nitzschia minuta & 3 & 1 & & 1 & 6 & & 3 & 5 & 8 & 6 & & \\
\hline Nitzchia palacea & 2 & 1 & & 1 & & & & & & & & \\
\hline Nitzschia palea sensu lato & 141 & 98 & 64 & 112 & 128 & 6 & 71 & 83 & 48 & 42 & 2 & 87 \\
\hline Nitzschia recta & & & 1 & & & & & & & & & \\
\hline \multicolumn{13}{|l|}{ Nitzschia sp6 } \\
\hline Pinnularia biceps (var 1) & 14 & 1 & 15 & 11 & 19 & 4 & 14 & 13 & 8 & 13 & 13 & 12 \\
\hline Pinnularia biceps (var 2) & 4 & 4 & & 5 & 1 & 2 & & 1 & & & & \\
\hline Pinnularia sp4 & & & & & & & & & & & 1 & \\
\hline Pinnularia sp5 & 1 & 1 & 3 & 1 & 2 & & 1 & & 1 & & & \\
\hline \multicolumn{13}{|l|}{ Pinnularia sp6 } \\
\hline \multicolumn{13}{|l|}{ Psamnothidium sp1 } \\
\hline Pseudostaurosira brevistriata & 1 & & & & & & & & & & & 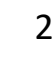 \\
\hline Rhopalodia gibba & & & & & & & & & & & 1 & \\
\hline Rossitidium petersonii & 1 & & & & & 1 & & & & & & \\
\hline \multicolumn{13}{|l|}{ Sellaphora capitata } \\
\hline Sellaphora pupula & 36 & 26 & 19 & 29 & 34 & 19 & 26 & 27 & 9 & 21 & 28 & 15 \\
\hline
\end{tabular}




\begin{tabular}{|c|c|c|c|c|c|c|c|c|c|c|c|c|}
\hline \multirow[b]{2}{*}{ Updated Species Name (Guiry and Guiry, 2018) } & \multicolumn{12}{|c|}{ Depth (cm) } \\
\hline & 81 & 82 & 83 & 84 & 85 & 86 & 87 & 88 & 89 & 90 & 91 & 92 \\
\hline Sellaphora pupula var. obesa & 3 & 2 & 3 & 2 & 6 & & 4 & 4 & 6 & 6 & 3 & 2 \\
\hline Sellaphora sp3 & 11 & 9 & 9 & 1 & 22 & 8 & 14 & 15 & 13 & 15 & 8 & 6 \\
\hline \multicolumn{13}{|l|}{ Sellaphora sp4 } \\
\hline \multicolumn{13}{|l|}{ Sellaphora rectangularis } \\
\hline \multicolumn{13}{|l|}{ Sellaphora sp7 } \\
\hline Stauroneis gracilis & 2 & 2 & 4 & 3 & 5 & 2 & 2 & 1 & 1 & & & \\
\hline Stauroneis reichardtii & 17 & 13 & 1 & 15 & 21 & 1 & 14 & 15 & 8 & 11 & 1 & 11 \\
\hline Stauroneis siberica & 4 & 2 & 3 & 2 & 3 & 1 & 2 & 2 & 1 & 2 & 3 & 3 \\
\hline Staurneis sp4 & 3 & 3 & 6 & 3 & 4 & 1 & 2 & & & & & \\
\hline \multicolumn{13}{|l|}{ Staurosira venter } \\
\hline \multicolumn{13}{|l|}{ Staurosira sp2 } \\
\hline \multicolumn{13}{|l|}{ Surirella sp1 } \\
\hline \multicolumn{13}{|l|}{ Tabellaria sp1 } \\
\hline \multicolumn{13}{|l|}{ Thalassiosira sp1 } \\
\hline \multicolumn{13}{|l|}{ Trybonella sp1 } \\
\hline \multicolumn{13}{|l|}{ Trybonella } \\
\hline \multicolumn{13}{|l|}{ Ulnaria sp1 } \\
\hline \multicolumn{13}{|l|}{ Unidentified taxon 4} \\
\hline \multicolumn{13}{|l|}{ Unidentified taxon 6} \\
\hline \multicolumn{13}{|l|}{ Unidentified taxon 7} \\
\hline \multicolumn{13}{|l|}{ Unidentified taxon 8} \\
\hline \multicolumn{13}{|l|}{ Unidentified taxon 9} \\
\hline \multicolumn{13}{|l|}{ Unidentified taxon 10} \\
\hline \multicolumn{13}{|l|}{ Unidentified taxon 11} \\
\hline \multicolumn{13}{|l|}{ Unidentified taxon 12} \\
\hline \multicolumn{13}{|l|}{ Unidentified taxon 13} \\
\hline \multicolumn{13}{|l|}{ Unidentified taxon 14} \\
\hline \multicolumn{13}{|l|}{ Unidentified taxon 15} \\
\hline \multicolumn{13}{|l|}{ Unidentified taxon 16} \\
\hline Unidentified taxon 18 & & & & & & & & & & & & \\
\hline Unidentified taxon 19 & & & & & & & & & & & & \\
\hline Unidentified taxon 20 & & & & & & & & & & & & \\
\hline Unidentified taxon 21 & & & & & & & & & & & & \\
\hline
\end{tabular}




\begin{tabular}{|c|c|c|c|c|c|c|c|c|c|c|c|c|}
\hline \multirow[b]{2}{*}{ Updated Species Name (Guiry and Guiry, 2018) } & \multicolumn{12}{|c|}{ Depth (cm) } \\
\hline & 93 & 94 & 95 & 96 & 97 & 98 & 99 & 100 & 101 & 102 & 103 & 10 \\
\hline Achnanthidium atomus & 35 & 17 & 43 & 44 & 49 & 3 & 44 & 34 & 35 & 3 & 54 & 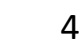 \\
\hline Achnanthidium minutissimum & 7 & 12 & 17 & 13 & 19 & 14 & 9 & 16 & 4 & 5 & 18 & 1 \\
\hline Achnanthidium sp6 & & & & & & 1 & & & & & & \\
\hline Achnanthidium sp7 & & & & & & & & & & & & \\
\hline Amphora ovalis & 2 & & & & & & 1 & & & & & \\
\hline Aneumastus sp1 & & & & & & & & & & & & \\
\hline Brachysira microcephala & 32 & 39 & 31 & 41 & 38 & 17 & 34 & 26 & 57 & 23 & 55 & 28 \\
\hline Cyclostephanos invisitatus & & 1 & & 1 & & 1 & 1 & & & & 3 & 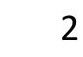 \\
\hline Cyclotella distinguenda & & & & & & 3 & 1 & & & & 4 & 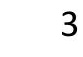 \\
\hline Cyclotella intermedia & & & & & & & & 1 & & & & \\
\hline Cyclotella sp6 & & & & & & & & & & 5 & & \\
\hline Cymbella sp1 & & 1 & 5 & & 2 & 2 & 6 & 2 & & 1 & 9 & \\
\hline Cymbopleura angustata & 6 & 6 & 2 & 4 & 1 & 6 & 3 & 2 & & 3 & 6 & \\
\hline Cymbopleura ehrenbergii & 2 & & 4 & 1 & 6 & 1 & 3 & 5 & 13 & 5 & 13 & \\
\hline Cymbopleura sp2 & & & 6 & 5 & 2 & 3 & 1 & 3 & 3 & 4 & 4 & \\
\hline Denticula elegans & & 3 & & & & 5 & & & 2 & & 3 & \\
\hline Dipuneis occulata & & & 4 & 1 & 3 & 3 & 1 & & & & & \\
\hline Discostella pseudostelligera & 1 & 1 & & & 1 & & 2 & 5 & & 1 & 7 & \\
\hline Discostella stelligera & & & & & & & & & & & & \\
\hline Encyonema cesatii sensu strata & 5 & 1 & 8 & 11 & 5 & 1 & 1 & 12 & 5 & 1 & 1 & 3 \\
\hline Encyonema elginese & 4 & & & & & & & & & & & \\
\hline Encyonema silesiacum & 3 & 4 & & & 1 & 4 & & 1 & 2 & 1 & 3 & \\
\hline Encyonema sp3 & & & & & & 1 & & & & 1 & & \\
\hline Encyonema sp5 & 4 & 2 & 2 & 3 & 1 & 9 & 2 & 5 & 17 & 3 & 12 & \\
\hline Encyonema minuta & & & & & & & & 2 & 5 & 14 & 6 & \\
\hline Encyonema silicum & & & & 1 & & & & 1 & 7 & 4 & 6 & 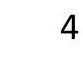 \\
\hline Encyonopsis cesetii & 2 & 1 & & & 2 & & & & & 1 & 4 & 3 \\
\hline Encyonopsis falaisensis & 3 & 4 & 6 & 6 & 2 & 6 & 2 & & 5 & 1 & 7 & \\
\hline Encyonopsis microcephala & 32 & 19 & 18 & 32 & 23 & 32 & 27 & 27 & 33 & 27 & 43 & 27 \\
\hline Fragillaria sp1 & & & 4 & & & 1 & 2 & & & & 3 & 2 \\
\hline Frustrulia vulgaris & & & & & & & & & & & & \\
\hline Gomphoneis sp1 & & & & & 1 & & & & & & & \\
\hline Hantzschia amphioxys & & & 1 & 1 & 1 & & 1 & & 1 & & & \\
\hline Lindavia michiganiana & 3 & 3 & 4 & 2 & 6 & 8 & 7 & 8 & 4 & 3 & 7 & \\
\hline Mayamaea sp1 & & & & & & & & & & 1 & & \\
\hline
\end{tabular}




\begin{tabular}{|c|c|c|c|c|c|c|c|c|c|c|c|c|}
\hline \multirow[b]{2}{*}{ Updated Species Name (Guiry and Guiry, 2018) } & \multicolumn{12}{|c|}{ Depth (cm) } \\
\hline & 93 & 94 & 95 & 96 & 97 & 98 & 99 & 100 & 101 & 102 & 103 & 10 \\
\hline Navicula antonii & & 2 & & 4 & 4 & 4 & 1 & & & & & \\
\hline Navicula cryptocephala & 2 & 1 & 2 & 1 & 1 & & & & 1 & 1 & & \\
\hline Navicula cryptotenella & 43 & 47 & 6 & 42 & 48 & 5 & 54 & 46 & 48 & 24 & & \\
\hline Navicula gomphonema & 11 & 2 & 3 & 2 & 3 & 1 & & 6 & 3 & 4 & & \\
\hline \multicolumn{13}{|l|}{ Nupela impexiformis } \\
\hline Navicula notha & 9 & 11 & 5 & 5 & 4 & 2 & 5 & 1 & 1 & 5 & & \\
\hline Navicula Radiosa & & 2 & 5 & 1 & 1 & 2 & 7 & 2 & 5 & & & \\
\hline Navicula schweigeri & 16 & 11 & 7 & 9 & 14 & 7 & 4 & 12 & 1 & 3 & & 28 \\
\hline Navicula wildii & & & 1 & 1 & 1 & 3 & 4 & 2 & 3 & & & \\
\hline Navicula sp4 & 2 & 1 & 3 & 3 & & & 2 & & 1 & & & \\
\hline Navicula sp8 & 11 & 15 & 15 & 4 & 7 & 11 & 1 & & 18 & 1 & & \\
\hline Navicula sp9 & & & & & & & & & 2 & 1 & & \\
\hline \multicolumn{13}{|l|}{ Navicula sp 10} \\
\hline Navicula sp12 & & 1 & & & & 1 & & 1 & & & & \\
\hline Navicula sp13 & 2 & 1 & & & & 1 & 1 & 2 & & & & \\
\hline Navicula sp14 & & & & & 1 & & 4 & 2 & & & & \\
\hline Neidium afinne & 3 & & & 1 & & & 1 & 1 & & 1 & & \\
\hline Neidium sp2 & 3 & 4 & 2 & 4 & 6 & 4 & 5 & 8 & 7 & 4 & & \\
\hline Nitzschia amphibia & & & & 1 & 1 & & & & & & & \\
\hline Nitzschia minuta & & & 1 & 1 & 5 & 4 & & & 45 & 15 & & \\
\hline Nitzchia palacea & & & & & & & & & 1 & & & \\
\hline Nitzschia palea sensu lato & 14 & 116 & 8 & 16 & 114 & 79 & 95 & 14 & 87 & 7 & & 1 \\
\hline \multicolumn{13}{|l|}{ Nitzschia recta } \\
\hline Nitzschia sp6 & & & & & & 3 & & & & & & \\
\hline Pinnularia biceps (var 1) & 15 & 14 & 17 & 4 & 6 & 1 & 11 & 13 & 5 & 7 & & 1 \\
\hline Pinnularia biceps (var 2) & & & & & 1 & 4 & & & 1 & & & \\
\hline Pinnularia sp4 & & & 1 & & 1 & & & & & & & \\
\hline \multicolumn{13}{|l|}{ Pinnularia sp5 } \\
\hline Pinnularia sp6 & & & 1 & & & & & & & & & \\
\hline Psamnothidium sp1 & & & & & 1 & & & & & & & \\
\hline Pseudostaurosira brevistriata & & & & & 1 & 2 & 3 & & 2 & 5 & & \\
\hline Rhopalodia gibba & & 2 & 1 & 2 & 1 & & & & & & & \\
\hline Rossitidium petersonii & 1 & 1 & 3 & 8 & & 2 & 2 & 4 & & & 7 & \\
\hline Sellaphora capitata & & 3 & 2 & 3 & 2 & 3 & & & & & & \\
\hline Sellaphora pupula & 18 & 19 & 28 & 17 & 25 & 2 & 26 & 39 & 24 & 27 & & 32 \\
\hline
\end{tabular}




\begin{tabular}{|c|c|c|c|c|c|c|c|c|c|c|c|c|}
\hline Updated Species Name (Guiry and Guiry, 2018) & 93 & 94 & 95 & 96 & 97 & 98 & 99 & 100 & 101 & 102 & 103 & 104 \\
\hline Sellaphora pupula var. obesa & 2 & 4 & 2 & 4 & 1 & 3 & 1 & 2 & 2 & 5 & & 4 \\
\hline Sellaphora sp3 & 8 & 13 & 6 & 9 & 7 & 9 & 11 & 7 & 22 & 18 & & 1 \\
\hline Sellaphora sp4 & & & & & & & & & 3 & 1 & & \\
\hline \multicolumn{13}{|l|}{ Sellaphora rectangularis } \\
\hline Sellaphora sp7 & & 2 & 3 & 6 & & & & & & & & \\
\hline Stauroneis gracilis & 1 & & & & & & & & & & & \\
\hline Stauroneis reichardtii & 5 & 9 & 11 & 12 & 11 & 12 & 15 & 9 & 1 & 15 & & 1 \\
\hline Stauroneis siberica & & 3 & 2 & 3 & 1 & 6 & 4 & & 2 & 7 & & 6 \\
\hline Staurneis sp4 & & & & & & & & & 1 & 1 & & 1 \\
\hline Staurosira venter & & & & & & & 1 & 2 & 7 & 24 & & 23 \\
\hline \multicolumn{13}{|l|}{ Staurosira sp2 } \\
\hline \multicolumn{13}{|l|}{ Surirella sp1 } \\
\hline Tabellaria sp1 & & & & & & & & & & 1 & & \\
\hline \multicolumn{13}{|l|}{ Thalassiosira sp1 } \\
\hline Trybonella sp1 & & & & & & & & & & 1 & & \\
\hline \multicolumn{13}{|l|}{ Trybonella } \\
\hline \multicolumn{13}{|l|}{ Ulnaria sp1 } \\
\hline \multicolumn{13}{|l|}{ Unidentified taxon 4} \\
\hline \multicolumn{13}{|l|}{ Unidentified taxon 6} \\
\hline \multicolumn{13}{|l|}{ Unidentified taxon 7} \\
\hline \multicolumn{13}{|l|}{ Unidentified taxon 8} \\
\hline \multicolumn{13}{|l|}{ Unidentified taxon 9} \\
\hline \multicolumn{13}{|l|}{ Unidentified taxon 10} \\
\hline Unidentified taxon 11 & 6 & 2 & & & & & & & & & & \\
\hline \multicolumn{13}{|l|}{ Unidentified taxon 12} \\
\hline \multicolumn{13}{|l|}{ Unidentified taxon 13} \\
\hline Unidentified taxon 14 & & & 1 & & & 1 & & & & 8 & & \\
\hline \multicolumn{13}{|l|}{ Unidentified taxon 15} \\
\hline Unidentified taxon 16 & & & & & & & & 1 & & & & \\
\hline \multicolumn{13}{|l|}{ Unidentified taxon 18} \\
\hline \multicolumn{13}{|l|}{ Unidentified taxon 19} \\
\hline \multicolumn{13}{|l|}{ Unidentified taxon 20} \\
\hline Unidentified taxon 21 & & & & & & & & & & & & \\
\hline
\end{tabular}




\begin{tabular}{|c|c|c|c|c|c|c|c|c|c|c|c|c|}
\hline $\begin{array}{l}\text { Updated Species Name (Guiry and Guiry, } \\
\text { 2018) }\end{array}$ & $\begin{array}{l}\text { Dept } \\
105 \\
\end{array}$ & $\begin{array}{l}\mathrm{h}(\mathrm{cm}) \\
106 \\
\end{array}$ & 107 & 108 & 109 & 110 & 111 & 112 & 113 & 114 & 115 & 116 \\
\hline Achnanthidium atomus & 63 & 51 & 71 & 41 & 35 & 76 & 61 & 37 & 87 & 59 & 44 & 2 \\
\hline Achnanthidium minutissimum & 16 & 8 & 9 & 6 & 8 & 19 & 3 & 5 & 4 & 7 & 7 & 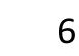 \\
\hline Achnanthidium sp6 & & & & & & 1 & & 1 & & & & \\
\hline Achnanthidium sp7 & & & & & & & & & & & & \\
\hline Amphora ovalis & & & 1 & & & & & & & & & \\
\hline Aneumastus sp1 & & & & & & & & & & & & \\
\hline Brachysira microcephala & 56 & 41 & 56 & 39 & 28 & 42 & 27 & 9 & 3 & 24 & 18 & 18 \\
\hline Cyclostephanos invisitatus & 2 & 1 & & 1 & & 5 & & & & 1 & 1 & 3 \\
\hline Cyclotella distinguenda & 3 & 1 & 1 & 1 & & 4 & 2 & 1 & 1 & & 1 & \\
\hline Cyclotella intermedia & & & & & & & & & & & & \\
\hline Cyclotella sp6 & & & & & & & 1 & & & & & \\
\hline Cymbella sp1 & 5 & & & & & & & & & 2 & 6 & \\
\hline Cymbopleura angustata & 5 & 4 & 3 & 4 & 6 & 3 & 1 & 3 & 1 & 1 & & \\
\hline Cymbopleura ehrenbergii & 11 & 4 & 1 & 2 & & 7 & 2 & 1 & 8 & 6 & 8 & \\
\hline Cymbopleura sp2 & 2 & 1 & & 3 & & & & & & 2 & 2 & \\
\hline Denticula elegans & 2 & & 2 & & & 2 & & & 2 & & 3 & \\
\hline Dipuneis occulata & 2 & 3 & 2 & 2 & 3 & 1 & & 3 & 6 & 5 & 3 & \\
\hline Discostella pseudostelligera & 4 & & 1 & 1 & & 4 & & & 1 & & 1 & \\
\hline Discostella stelligera & & & & & & & & & & & & \\
\hline Encyonema cesatii sensu strata & 9 & 6 & 8 & 8 & 4 & 13 & 6 & 7 & 7 & 6 & 3 & \\
\hline Encyonema elginese & & & & & & 1 & & 1 & & & & \\
\hline Encyonema silesiacum & 1 & & 1 & & & & 1 & & 3 & 1 & 1 & 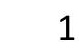 \\
\hline Encyonema sp3 & & & & & & & & 3 & & 1 & & \\
\hline Encyonema sp5 & 9 & 3 & 5 & 3 & 2 & 7 & 6 & & 5 & 2 & 2 & \\
\hline Encyonema minuta & 6 & 6 & 5 & 8 & 5 & 2 & 8 & 9 & 22 & 16 & 22 & 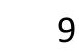 \\
\hline Encyonema silicum & 4 & 2 & & 3 & 7 & 1 & & 6 & & 7 & 3 & 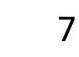 \\
\hline Encyonopsis cesetii & 3 & 1 & 1 & & & 6 & & & 1 & & 1 & \\
\hline Encyonopsis falaisensis & 5 & 4 & 6 & 6 & 5 & 6 & 9 & 2 & 5 & 2 & 2 & \\
\hline Encyonopsis microcephala & 39 & 22 & 19 & 17 & 2 & 24 & 1 & 1 & 19 & 18 & 15 & 13 \\
\hline Fragillaria sp1 & 2 & & & & & & & & & & & 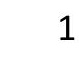 \\
\hline Frustrulia vulgaris & & & & & & & & & & & & \\
\hline Gomphoneis sp1 & & & & & & & & & & & & \\
\hline Hantzschia amphioxys & & 1 & 1 & 1 & & 2 & 1 & & & & & \\
\hline Lindavia michiganiana & 6 & 2 & 4 & 1 & 6 & 9 & 1 & 3 & 5 & 4 & 5 & \\
\hline Mayamaea sp1 & 1 & 1 & & & & & & & & & & \\
\hline
\end{tabular}




\begin{tabular}{|c|c|c|c|c|c|c|c|c|c|c|c|c|}
\hline $\begin{array}{l}\text { Updated Species Name (Guiry and Guiry, } \\
\text { 2018) }\end{array}$ & $\begin{array}{l}\text { Dept } \\
105\end{array}$ & $\begin{array}{l}\mathrm{h}(\mathrm{cm} \\
106\end{array}$ & 107 & 108 & 109 & 110 & 111 & 112 & 113 & 114 & 115 & 116 \\
\hline Navicula antonii & & & 2 & & & & 3 & 1 & & 2 & 4 & 3 \\
\hline Navicula cryptocephala & 6 & 9 & 23 & 8 & 6 & & 4 & 3 & 21 & 14 & 1 & 1 \\
\hline Navicula cryptotenella & 27 & 45 & 57 & 41 & 26 & 6 & 55 & 41 & 42 & 42 & 35 & 18 \\
\hline Navicula gomphonema & 1 & 1 & 3 & & & 4 & & & 2 & 2 & 3 & 3 \\
\hline Nupela impexiformis & & & & & & & & & & & & \\
\hline Navicula notha & 9 & 11 & 25 & 3 & 11 & 24 & 12 & 3 & 12 & 6 & 4 & 3 \\
\hline Navicula Radiosa & & 1 & & 1 & 1 & 2 & 3 & 5 & 1 & 5 & 4 & 4 \\
\hline Navicula schweigeri & 1 & 13 & 2 & 7 & 1 & 17 & 2 & 7 & 6 & 1 & 16 & 9 \\
\hline Navicula wildii & 5 & 6 & 17 & 2 & 5 & 3 & 11 & 7 & 14 & 9 & 5 & 3 \\
\hline Navicula sp4 & & 2 & & 6 & 6 & & & 1 & 4 & 1 & 1 & \\
\hline Navicula sp8 & 2 & 2 & 9 & & 2 & 14 & 7 & 12 & 8 & 9 & 5 & 3 \\
\hline Navicula sp9 & & & & & & & & & & & & \\
\hline Navicula sp 10 & & & & & & & & & & & & \\
\hline Navicula sp12 & & & & & & & & & & & & \\
\hline Navicula sp13 & & & & 2 & 2 & & 2 & & & & & \\
\hline Navicula sp14 & & & & & & & & & & & & \\
\hline Neidium afinne & & 2 & 1 & 5 & 1 & & 2 & 2 & 1 & 2 & 1 & 1 \\
\hline Neidium sp2 & 3 & 4 & 9 & 2 & 4 & 7 & 7 & 2 & 9 & 8 & 7 & 7 \\
\hline Nitzschia amphibia & & & & & & & & & & & & \\
\hline Nitzschia minuta & 2 & 4 & & 5 & 9 & & 8 & & 1 & 3 & 3 & 6 \\
\hline Nitzchia palacea & & & & & & & & & & & & \\
\hline Nitzschia palea sensu lato & 84 & 147 & 174 & 145 & 123 & 193 & 141 & 166 & 174 & 173 & 12 & 72 \\
\hline Nitzschia recta & & & & & & & & & & & & \\
\hline Nitzschia sp6 & & & & & & & & & & & & \\
\hline Pinnularia biceps (var 1) & 9 & 14 & 17 & 1 & 11 & 12 & 6 & 14 & 11 & 18 & 14 & 15 \\
\hline Pinnularia biceps (var 2) & & & & & & & & & & 1 & 1 & 3 \\
\hline Pinnularia sp4 & & & & & & & & & & & & \\
\hline Pinnularia sp5 & & & & & & & & & & & & \\
\hline Pinnularia sp6 & & & & & & & & & & & & \\
\hline Psamnothidium sp1 & & & & & & 1 & & & 4 & 2 & 1 & 1 \\
\hline Pseudostaurosira brevistriata & & & & & & & & & & & & \\
\hline Rhopalodia gibba & & & 2 & & & 1 & & 1 & & & & \\
\hline Rossitidium petersonii & 5 & 2 & & 1 & 5 & 8 & 7 & 2 & 1 & 2 & 1 & 1 \\
\hline Sellaphora capitata & 2 & 2 & & & & & & & & & & \\
\hline Sellaphora pupula & 18 & 23 & 28 & 9 & 2 & 41 & 8 & 19 & 26 & 23 & 23 & 1 \\
\hline
\end{tabular}




\begin{tabular}{|c|c|c|c|c|c|c|c|c|c|c|c|c|}
\hline $\begin{array}{l}\text { Updated Species Name (Guiry and Guiry, } \\
\text { 2018) }\end{array}$ & $\begin{array}{l}\text { Dept } \\
105 \\
\end{array}$ & $\begin{array}{l}\mathrm{h}(\mathrm{cm}) \\
106\end{array}$ & 107 & 108 & 109 & 110 & 111 & 112 & 113 & 114 & 115 & 116 \\
\hline Sellaphora pupula var. obesa & 1 & 1 & & & & 7 & 4 & 4 & 3 & 3 & 2 & 1 \\
\hline Sellaphora sp3 & 2 & 3 & 9 & 2 & 4 & 14 & 7 & 6 & 3 & 6 & 6 & 4 \\
\hline Sellaphora sp4 & & & & & & & & & & & & 1 \\
\hline $\begin{array}{l}\text { Sellaphora rectangularis } \\
\text { Sellaphora } s p 7\end{array}$ & & & 2 & & & & & 1 & & & & \\
\hline Stauroneis gracilis & & & & & & 1 & & & & & & \\
\hline Stauroneis reichardtii & 7 & 12 & 15 & 12 & 11 & 12 & 14 & 14 & 12 & 11 & 1 & 3 \\
\hline Stauroneis siberica & 3 & 3 & 4 & 1 & 2 & 3 & 3 & 2 & 3 & 3 & 6 & 3 \\
\hline Staurneis sp4 & & & & & & & & & & 1 & 1 & 3 \\
\hline Staurosira venter & 1 & 12 & 9 & 5 & 22 & 27 & 22 & 14 & 44 & 39 & 49 & 33 \\
\hline Staurosira sp2 & & & & & & 2 & & & & & & \\
\hline Surirella sp1 & & & & & & & 1 & & & & & \\
\hline Tabellaria sp1 & & & & & & & & & & & & \\
\hline Thalassiosira sp1 & & & & & & 2 & & & & & & \\
\hline Trybonella sp1 & & & & & & & & & & & & \\
\hline Trybonella & & & & & & & & & & & & \\
\hline Ulnaria sp1 & & & & & & & & & & & & \\
\hline Unidentified taxon 4 & & & & & & & & & & & & \\
\hline Unidentified taxon 6 & & & & & & & & & & & & \\
\hline Unidentified taxon 7 & & & & & & & & & & & & \\
\hline Unidentified taxon 8 & & & & & & & & & & & & \\
\hline Unidentified taxon 9 & & & & & & & & & & & & \\
\hline Unidentified taxon 10 & & & & & & & & & & & & \\
\hline Unidentified taxon 11 & & & & & & & & & & & & \\
\hline Unidentified taxon 12 & & & & & & & & & & & & \\
\hline Unidentified taxon 13 & & & & & & & & & & & & \\
\hline Unidentified taxon 14 & & 2 & 3 & 4 & & & 5 & 4 & 4 & 3 & 1 & \\
\hline Unidentified taxon 15 & & & & 1 & & & & & & & & \\
\hline Unidentified taxon 16 & & & & & & & & & & & & \\
\hline Unidentified taxon 18 & & & & & & & & & & & & \\
\hline Unidentified taxon 19 & & & & & & & & & & & & \\
\hline Unidentified taxon 20 & & & & & & & & & & & & \\
\hline Unidentified taxon 21 & & & & & & & & & & & & \\
\hline
\end{tabular}




\begin{tabular}{|c|c|c|c|c|c|c|c|c|}
\hline \multirow[b]{2}{*}{ Updated Species Name (Guiry and Guiry, 2018) } & \multicolumn{8}{|c|}{ Depth (cm) } \\
\hline & 117 & 118 & 119 & 120 & 121 & 122 & 123 & 124 \\
\hline Achnanthidium atomus & 38 & 18 & 32 & 3 & 46 & 45 & 51 & 37 \\
\hline Achnanthidium minutissimum & 12 & 7 & 15 & 15 & 12 & 4 & 4 & 2 \\
\hline \multicolumn{9}{|l|}{ Achnanthidium sp6 } \\
\hline \multicolumn{9}{|l|}{ Achnanthidium sp7 } \\
\hline Amphora ovalis & & & & & & & 1 & \\
\hline \multicolumn{9}{|l|}{ Aneumastus sp1 } \\
\hline Brachysira microcephala & 18 & 3 & 1 & 13 & 14 & 9 & 12 & 19 \\
\hline Cyclostephanos invisitatus & 2 & & & & & & & \\
\hline Cyclotella distinguenda & 1 & 1 & 1 & & & & 2 & 1 \\
\hline Cyclotella intermedia & 1 & 1 & 1 & & & & & \\
\hline \multicolumn{9}{|l|}{ Cyclotella sp6 } \\
\hline Cymbella sp1 & 1 & 7 & 1 & 7 & 5 & & & \\
\hline Cymbopleura angustata & & & & & & & 2 & 1 \\
\hline Cymbopleura ehrenbergii & 1 & 6 & 7 & 4 & 4 & 2 & 1 & 2 \\
\hline Cymbopleura sp2 & 5 & 1 & 4 & 6 & 5 & 2 & & \\
\hline Denticula elegans & 5 & 6 & 4 & & & & & \\
\hline Dipuneis occulata & 2 & & 2 & 4 & 4 & 3 & 2 & 3 \\
\hline Discostella pseudostelligera & 1 & 1 & 1 & & & & & 2 \\
\hline Discostella stelligera & 1 & & & & & & & 1 \\
\hline Encyonema cesatii sensu strata & 2 & 1 & 1 & & 1 & 2 & 5 & 9 \\
\hline Encyonema elginese & & & & & & & & 2 \\
\hline Encyonema silesiacum & 1 & & & & & & 1 & \\
\hline \multicolumn{9}{|l|}{ Encyonema sp3 } \\
\hline Encyonema sp5 & 1 & & 1 & 3 & 2 & & & 4 \\
\hline Encyonema minuta & 28 & 22 & 23 & 1 & 14 & 12 & 15 & 7 \\
\hline Encyonema silicum & 6 & & 3 & 6 & 4 & & 1 & 1 \\
\hline Encyonopsis cesetii & 2 & 3 & 3 & 1 & 1 & 1 & 1 & 2 \\
\hline Encyonopsis falaisensis & 2 & 3 & 2 & & 1 & 2 & 2 & 3 \\
\hline Encyonopsis microcephala & 18 & 7 & 1 & 7 & 7 & 5 & 3 & 16 \\
\hline Fragillaria sp1 & 1 & & & & & & & \\
\hline \multicolumn{9}{|l|}{ Frustrulia vulgaris } \\
\hline \multicolumn{9}{|l|}{ Gomphoneis sp1 } \\
\hline Hantzschia amphioxys & & & & & & & & 1 \\
\hline Lindavia michiganiana & 6 & 4 & 6 & 4 & 4 & 3 & & 4 \\
\hline Mayamaea sp1 & & & & & & & & \\
\hline
\end{tabular}




\begin{tabular}{|c|c|c|c|c|c|c|c|c|}
\hline \multirow[b]{2}{*}{ Updated Species Name (Guiry and Guiry, 2018) } & \multicolumn{8}{|c|}{ Depth (cm) } \\
\hline & 117 & 118 & 119 & 120 & 121 & 122 & 123 & 124 \\
\hline Navicula antonii & 8 & 6 & 5 & 1 & 1 & 1 & & \\
\hline Navicula cryptocephala & 9 & & 1 & 3 & 2 & & 5 & 5 \\
\hline Navicula cryptotenella & 43 & 3 & 27 & 9 & 27 & 37 & 44 & 38 \\
\hline Navicula gomphonema & 5 & 3 & 2 & & & & & 1 \\
\hline Nupela impexiformis & & & & & & & 1 & \\
\hline Navicula notha & 2 & & 6 & 1 & 12 & 9 & 13 & 9 \\
\hline Navicula Radiosa & 6 & 3 & 4 & 3 & 3 & 2 & & 1 \\
\hline Navicula schweigeri & 25 & 19 & 23 & 13 & 13 & 7 & 7 & 2 \\
\hline Navicula wildii & 2 & & & 1 & 5 & 8 & 5 & 6 \\
\hline Navicula sp4 & 1 & 1 & 1 & & & 1 & 2 & 3 \\
\hline Navicula sp8 & 6 & 4 & 6 & 4 & 4 & 2 & 4 & 5 \\
\hline \multicolumn{9}{|l|}{ Navicula sp9 } \\
\hline \multicolumn{9}{|l|}{ Navicula sp 10} \\
\hline \multicolumn{9}{|l|}{ Navicula sp12 } \\
\hline Navicula sp13 & & & & & & & 2 & 2 \\
\hline \multicolumn{9}{|l|}{ Navicula sp14 } \\
\hline Neidium afinne & 2 & 1 & 2 & 1 & 1 & 1 & & 3 \\
\hline Neidium sp2 & 9 & 3 & 3 & 1 & 3 & 5 & & 2 \\
\hline \multicolumn{9}{|l|}{ Nitzschia amphibia } \\
\hline Nitzschia minuta & 6 & 1 & 1 & & 1 & 2 & & 4 \\
\hline \multicolumn{9}{|l|}{ Nitzchia palacea } \\
\hline Nitzschia palea sensu lato & 99 & 4 & 68 & 6 & 19 & 119 & 114 & 19 \\
\hline Nitzschia recta & & & 1 & 3 & 2 & & & \\
\hline \multicolumn{9}{|l|}{ Nitzschia sp6 } \\
\hline Pinnularia biceps (var 1) & 19 & 7 & 14 & 13 & 16 & 12 & 12 & 1 \\
\hline Pinnularia biceps (var 2) & 2 & & 1 & 3 & 2 & 1 & & 1 \\
\hline \multicolumn{9}{|l|}{ Pinnularia sp4 } \\
\hline \multicolumn{9}{|l|}{ Pinnularia sp5 } \\
\hline \multicolumn{9}{|l|}{ Pinnularia sp6 } \\
\hline Psamnothidium sp1 & 1 & & & & & & & \\
\hline \multicolumn{9}{|l|}{ Pseudostaurosira brevistriata } \\
\hline \multicolumn{9}{|l|}{ Rhopalodia gibba } \\
\hline Rossitidium petersonii & 2 & 1 & 1 & & 2 & 4 & 4 & 7 \\
\hline \multicolumn{9}{|l|}{ Sellaphora capitata } \\
\hline Sellaphora pupula & 28 & 21 & 22 & 1 & 14 & 13 & 13 & 8 \\
\hline
\end{tabular}




\begin{tabular}{|c|c|c|c|c|c|c|c|c|}
\hline \multirow[b]{2}{*}{ Updated Species Name (Guiry and Guiry, 2018) } & \multicolumn{8}{|c|}{ Depth (cm) } \\
\hline & 117 & 118 & 119 & 120 & 121 & 122 & 123 & 124 \\
\hline Sellaphora pupula var. obesa & 2 & 1 & 3 & 3 & 2 & 1 & & 2 \\
\hline Sellaphora sp3 & 1 & 7 & 17 & 18 & 15 & 5 & 2 & 4 \\
\hline Sellaphora sp4 & 1 & & & 1 & 1 & & & \\
\hline Sellaphora rectangularis & & & & & & & & 1 \\
\hline Sellaphora sp7 & & & & & & & & \\
\hline Stauroneis gracilis & & & & & & & & \\
\hline Stauroneis reichardtii & 13 & 12 & 18 & 15 & 12 & 4 & 13 & 7 \\
\hline Stauroneis siberica & 9 & 7 & 6 & 1 & 4 & 6 & 3 & 2 \\
\hline Staurneis sp4 & 2 & & & & & & & \\
\hline Staurosira venter & 67 & 42 & 66 & 55 & 8 & 74 & 79 & 76 \\
\hline Staurosira sp2 & & & & & & & & \\
\hline Surirella sp1 & & & & & & & & \\
\hline Tabellaria sp1 & & & & & & & & \\
\hline Thalassiosira sp1 & & & & & & & & \\
\hline Trybonella sp1 & & & & & & & & \\
\hline Trybonella & & & & & & & & \\
\hline Ulnaria sp1 & & & & & & & & \\
\hline Unidentified taxon 4 & & & & & & & & \\
\hline Unidentified taxon 6 & & & & & & & & \\
\hline Unidentified taxon 7 & & & & & & & & \\
\hline Unidentified taxon 8 & & & & & & & & \\
\hline Unidentified taxon 9 & & & & & & & & \\
\hline Unidentified taxon 10 & & & & & & & & \\
\hline Unidentified taxon 11 & & & & & & 1 & & \\
\hline Unidentified taxon 12 & & & & 1 & 1 & & & \\
\hline Unidentified taxon 13 & & & & & & & & \\
\hline Unidentified taxon 14 & & & & & & & & 1 \\
\hline Unidentified taxon 15 & & & & & & & & \\
\hline Unidentified taxon 16 & & & & & & & & \\
\hline Unidentified taxon 18 & & & & & & & & \\
\hline Unidentified taxon 19 & & & & & & & & \\
\hline Unidentified taxon 20 & & & & & & & & \\
\hline Unidentified taxon 21 & & & & & & & & \\
\hline
\end{tabular}




\begin{tabular}{|c|c|c|c|c|c|c|c|}
\hline \multirow[b]{2}{*}{ Updated Species Name (Guiry and Guiry, 2018) } & \multicolumn{2}{|c|}{ Depth (cm) } & \multirow[b]{2}{*}{127} & \multirow[b]{2}{*}{128} & \multirow[b]{2}{*}{129} & \multirow[b]{2}{*}{130} & \multirow[b]{2}{*}{131} \\
\hline & 125 & 126 & & & & & \\
\hline Achnanthidium atomus & 3 & 46 & 52 & 93 & 6 & 6 & 5 \\
\hline Achnanthidium minutissimum & 4 & 2 & 1 & 2 & 4 & 8 & 4 \\
\hline Achnanthidium sp6 & 3 & 1 & & & & & \\
\hline Achnanthidium sp7 & & & & & & 1 & \\
\hline \multicolumn{8}{|l|}{ Amphora ovalis } \\
\hline \multicolumn{8}{|l|}{ Aneumastus sp1 } \\
\hline Brachysira microcephala & 32 & 29 & 2 & 13 & 1 & 13 & 9 \\
\hline Cyclostephanos invisitatus & & & & & 1 & 4 & \\
\hline Cyclotella distinguenda & 2 & 1 & & 1 & & & \\
\hline \multicolumn{8}{|l|}{ Cyclotella intermedia } \\
\hline Cyclotella sp6 & 1 & & & & & & \\
\hline \multicolumn{8}{|l|}{ Cymbella sp1 } \\
\hline Cymbopleura angustata & 1 & 1 & 2 & 2 & 1 & 2 & \\
\hline Cymbopleura ehrenbergii & 1 & 1 & 2 & 1 & 1 & 3 & 8 \\
\hline \multicolumn{8}{|l|}{ Cymbopleura sp2 } \\
\hline Denticula elegans & 2 & 1 & & & & & \\
\hline Dipuneis occulata & 5 & 3 & 1 & 6 & 2 & 1 & 2 \\
\hline Discostella pseudostelligera & & & & 1 & 2 & 6 & \\
\hline \multicolumn{8}{|l|}{ Discostella stelligera } \\
\hline Encyonema cesatii sensu strata & 2 & 2 & 3 & 1 & 1 & 3 & 1 \\
\hline \multicolumn{8}{|l|}{ Encyonema elginese } \\
\hline \multicolumn{8}{|l|}{ Encyonema silesiacum } \\
\hline Encyonema sp3 & & & & 2 & 1 & 1 & 1 \\
\hline Encyonema sp5 & 2 & 1 & 1 & 5 & 1 & & 1 \\
\hline Encyonema minuta & 2 & 21 & 18 & 29 & 16 & 14 & 12 \\
\hline Encyonema silicum & 2 & 1 & 1 & & & 2 & 2 \\
\hline \multicolumn{8}{|l|}{ Encyonopsis cesetii } \\
\hline Encyonopsis falaisensis & & 1 & 2 & & & 1 & \\
\hline Encyonopsis microcephala & 4 & 3 & 3 & 7 & 6 & 1 & 18 \\
\hline \multicolumn{8}{|l|}{ Fragillaria sp1 } \\
\hline \multicolumn{8}{|l|}{ Frustrulia vulgaris } \\
\hline \multicolumn{8}{|l|}{ Gomphoneis sp1 } \\
\hline Hantzschia amphioxys & 1 & 1 & 1 & & & & \\
\hline Lindavia michiganiana & 2 & 2 & 2 & 2 & 1 & 1 & 2 \\
\hline Mayamaea sp1 & & & & & & & \\
\hline
\end{tabular}




\begin{tabular}{|c|c|c|c|c|c|c|c|}
\hline \multirow[b]{2}{*}{ Updated Species Name (Guiry and Guiry, 2018) } & \multicolumn{2}{|c|}{ Depth (cm) } & \multirow[b]{2}{*}{127} & \multirow[b]{2}{*}{128} & \multirow[b]{2}{*}{129} & \multirow[b]{2}{*}{130} & \multirow[b]{2}{*}{131} \\
\hline & 125 & 126 & & & & & \\
\hline Navicula antonii & & & & 3 & 3 & 5 & \\
\hline Navicula cryptocephala & 7 & 5 & 2 & & 1 & 4 & \\
\hline Navicula cryptotenella & 45 & 42 & 31 & 36 & 3 & 39 & 48 \\
\hline Navicula gomphonema & & & 1 & 2 & & & \\
\hline \multicolumn{8}{|l|}{ Nupela impexiformis } \\
\hline Navicula notha & 1 & 1 & 8 & 25 & 18 & 22 & 8 \\
\hline Navicula Radiosa & 1 & 1 & 1 & & & & \\
\hline Navicula schweigeri & 1 & 2 & 3 & 6 & 2 & 1 & 7 \\
\hline Navicula wildii & 7 & 6 & 4 & 3 & 4 & 8 & \\
\hline Navicula sp4 & 2 & 2 & 3 & 1 & & 1 & 3 \\
\hline Navicula sp8 & 8 & 5 & 2 & 2 & & & 4 \\
\hline \multicolumn{8}{|l|}{ Navicula sp9 } \\
\hline \multicolumn{8}{|l|}{ Navicula sp 10} \\
\hline \multicolumn{8}{|l|}{ Navicula sp12 } \\
\hline Navicula sp13 & & 1 & 2 & 1 & 1 & 3 & 3 \\
\hline \multicolumn{8}{|l|}{ Navicula sp14 } \\
\hline Neidium afinne & 1 & 2 & 4 & 1 & & & \\
\hline Neidium sp2 & & 1 & 2 & & 1 & 4 & 1 \\
\hline \multicolumn{8}{|l|}{ Nitzschia amphibia } \\
\hline Nitzschia minuta & 6 & 3 & 1 & 2 & 1 & 2 & \\
\hline Nitzchia palacea & & & & 1 & & & \\
\hline Nitzschia palea sensu lato & 116 & 122 & 11 & 132 & 117 & 157 & 19 \\
\hline \multicolumn{8}{|l|}{ Nitzschia recta } \\
\hline Nitzschia sp6 & & & & & & & 4 \\
\hline Pinnularia biceps (var 1) & 11 & 1 & 8 & 9 & 6 & 7 & 5 \\
\hline Pinnularia biceps (var 2) & 1 & & & & & & \\
\hline \multicolumn{8}{|l|}{ Pinnularia sp4 } \\
\hline \multicolumn{8}{|l|}{ Pinnularia sp5 } \\
\hline \multicolumn{8}{|l|}{ Pinnularia sp6 } \\
\hline \multicolumn{8}{|l|}{ Psamnothidium sp1 } \\
\hline Pseudostaurosira brevistriata & & & & & 1 & 4 & \\
\hline \multicolumn{8}{|l|}{ Rhopalodia gibba } \\
\hline Rossitidium petersonii & 2 & 1 & 1 & 1 & 3 & 8 & 2 \\
\hline \multicolumn{8}{|l|}{ Sellaphora capitata } \\
\hline Sellaphora pupula & 7 & 8 & 8 & 12 & 7 & 8 & 13 \\
\hline
\end{tabular}




\begin{tabular}{|c|c|c|c|c|c|c|c|}
\hline \multirow[b]{2}{*}{ Updated Species Name (Guiry and Guiry, 2018) } & \multicolumn{2}{|c|}{ Depth (cm) } & \multirow[b]{2}{*}{127} & \multirow[b]{2}{*}{128} & \multirow[b]{2}{*}{129} & \multirow[b]{2}{*}{130} & \multirow[b]{2}{*}{131} \\
\hline & 125 & 126 & & & & & \\
\hline Sellaphora pupula var. obesa & 1 & 1 & 2 & 2 & & & 1 \\
\hline Sellaphora sp3 & 5 & 4 & 3 & 11 & 6 & 6 & 3 \\
\hline Sellaphora sp4 & & & & & & 2 & \\
\hline Sellaphora rectangularis & 1 & & & & & & \\
\hline Sellaphora sp7 & & & & & & & \\
\hline Stauroneis gracilis & & & & & & & \\
\hline Stauroneis reichardtii & 8 & 7 & 6 & 3 & 4 & 8 & 12 \\
\hline Stauroneis siberica & 3 & 2 & 1 & 3 & 1 & 2 & 1 \\
\hline Staurneis sp4 & & & & & & & \\
\hline Staurosira venter & 43 & 84 & 18 & 116 & 67 & 54 & 69 \\
\hline Staurosira sp2 & & & & & & & \\
\hline Surirella sp1 & & & & & & & \\
\hline Tabellaria sp1 & & & & & & & \\
\hline Thalassiosira sp1 & & & & & & & \\
\hline Trybonella sp1 & & & & & & & \\
\hline Trybonella & & & & & & & \\
\hline Ulnaria sp1 & & & & & & & \\
\hline Unidentified taxon 4 & & & & & & & \\
\hline Unidentified taxon 6 & & & & & & & \\
\hline Unidentified taxon 7 & & & & & & & \\
\hline Unidentified taxon 8 & & & & & & & \\
\hline Unidentified taxon 9 & & & & & & & \\
\hline Unidentified taxon 10 & & & & & & & \\
\hline Unidentified taxon 11 & & & & & & & \\
\hline Unidentified taxon 12 & & & & & & & \\
\hline Unidentified taxon 13 & & & & & & & \\
\hline Unidentified taxon 14 & & & 1 & & & & \\
\hline Unidentified taxon 15 & & & & & & & \\
\hline Unidentified taxon 16 & & & & & & & \\
\hline Unidentified taxon 18 & & & & & & & \\
\hline Unidentified taxon 19 & & & & & & & \\
\hline Unidentified taxon 20 & & & & & & & \\
\hline Unidentified taxon 21 & & & & & & & \\
\hline
\end{tabular}




\section{Appendix B: Comprehensive Diatom Counts for PKT_2FR1}

Diatom taxa were identified with reference to photomicrographs of taxa from similar geographic regions and environmental conditions (Krammer and Lange-Bertalot, 1985-1991; Hartley, 1996). Species names were then corrected to current taxonomic nomenclature following Algaebase (Guiry and Guiry, 2018). This dataset is relevant to chapter 3. 


\begin{tabular}{|c|c|c|c|c|c|c|c|c|c|c|}
\hline $\begin{array}{l}\text { Updated Species Name (Guiry and Guiry, } \\
\text { 2018) }\end{array}$ & $\begin{array}{l}\begin{array}{l}\text { Depth } \\
\text { (cm) }\end{array} \\
54.5\end{array}$ & 54.6 & 54.7 & 54.8 & 54.9 & 55 & 55.1 & 55.2 & 55.3 & 55.4 \\
\hline Achnanthidium atomus & 19 & 14 & 24 & 25 & 14 & 33 & 22 & 34 & 40 & 30 \\
\hline Achnanthidium sp2 & 0 & 0 & 0 & 0 & 1 & 1 & 1 & 0 & 0 & 0 \\
\hline Achnanthidium minutissimum & 14 & 14 & 17 & 13 & 15 & 11 & 8 & 11 & 18 & 15 \\
\hline Achnanthidium sp4 & 3 & 2 & 2 & 3 & 6 & 2 & 3 & 5 & 3 & 0 \\
\hline Achnanthidium sp5 & 10 & 3 & 6 & 4 & 2 & 7 & 7 & 4 & 2 & 0 \\
\hline Amphora sp1 & 0 & 0 & 0 & 0 & 1 & 0 & 1 & 0 & 1 & 3 \\
\hline Aneumastus sp1 & 0 & 0 & 0 & 0 & 0 & 0 & 0 & 0 & 0 & 0 \\
\hline Brachysira microcephala & 107 & 105 & 80 & 123 & 95 & 87 & 78 & 99 & 96 & 68 \\
\hline Cyclostephanos invisitatus & 2 & 5 & 2 & 1 & 2 & 3 & 3 & 2 & 3 & 4 \\
\hline Lindavia michiganiana & 4 & 5 & 2 & 9 & 1 & 7 & 7 & 5 & 6 & 17 \\
\hline Cyclotella distinguenda & 5 & 3 & 2 & 5 & 8 & 5 & 12 & 10 & 12 & 8 \\
\hline Discostella pseudostelligera & 4 & 7 & 5 & 3 & 15 & 9 & 15 & 10 & 14 & 11 \\
\hline Cyclotella sp5 & 0 & 0 & 0 & 0 & 0 & 0 & 0 & 0 & 0 & 0 \\
\hline Cyclotella sp6 & 1 & 0 & 0 & 0 & 2 & 0 & 0 & 0 & 0 & 0 \\
\hline Cymbopleura sp1 & 3 & 5 & 2 & 3 & 4 & 1 & 0 & 0 & 3 & 0 \\
\hline Denticula elegans & 0 & 2 & 0 & 1 & 2 & 1 & 2 & 3 & 2 & 11 \\
\hline Encyonema sp1 & 3 & 4 & 3 & 3 & 3 & 6 & 3 & 4 & 4 & 5 \\
\hline Encyonopsis falaisensis & 3 & 12 & 10 & 6 & 15 & 5 & 6 & 9 & 7 & 6 \\
\hline Encyonema sp3 & 3 & 2 & 0 & 1 & 3 & 7 & 0 & 0 & 0 & 0 \\
\hline Encyonema sp4 & 1 & 1 & 3 & 2 & 1 & 0 & 0 & 1 & 3 & 1 \\
\hline Encyonema sp5 & 3 & 6 & 3 & 3 & 0 & 2 & 5 & 6 & 3 & 4 \\
\hline Encyonema hebridicum & 11 & 10 & 19 & 0 & 15 & 6 & 7 & 3 & 3 & 7 \\
\hline Encyonema sp7 & 3 & 6 & 6 & 1 & 7 & 8 & 1 & 1 & 2 & 3 \\
\hline Encyonema sp8 & 0 & 0 & 0 & 0 & 0 & 1 & 0 & 0 & 0 & 0 \\
\hline Encyonopsis microcephala & 56 & 53 & 66 & 59 & 65 & 55 & 78 & 91 & 74 & 65 \\
\hline Hantzschia amphioxys & 2 & 3 & 1 & 3 & 5 & 2 & 1 & 4 & 6 & 2 \\
\hline Mayamaea sp1 & 1 & 0 & 3 & 0 & 2 & 1 & 0 & 0 & 1 & 3 \\
\hline Unidentified taxa 11 & 2 & 2 & 2 & 1 & 0 & 0 & 1 & 0 & 2 & 2 \\
\hline Unidentified taxa 12 & 0 & 0 & 0 & 0 & 0 & 0 & 0 & 3 & 0 & 4 \\
\hline Unidentified taxa 13 & 0 & 0 & 0 & 0 & 0 & 0 & 1 & 0 & 0 & 0 \\
\hline Unidentified taxa 14 & 3 & 1 & 0 & 2 & 10 & 2 & 2 & 0 & 0 & 0 \\
\hline Unidentified taxa 15 & 0 & 0 & 0 & 1 & 0 & 0 & 0 & 0 & 0 & 0 \\
\hline Unidentified taxa 16 & 0 & 1 & 0 & 1 & 1 & 4 & 0 & 0 & 0 & 0 \\
\hline Unidentified taxa 17 & 0 & 0 & 0 & 0 & 0 & 0 & 0 & 0 & 0 & 0 \\
\hline Unidentified taxa 18 & 1 & 0 & 0 & 0 & 0 & 0 & 0 & 0 & 0 & 0 \\
\hline
\end{tabular}




\begin{tabular}{|c|c|c|c|c|c|c|c|c|c|c|}
\hline $\begin{array}{l}\text { Updated Species Name (Guiry and Guiry, } \\
\text { 2018) }\end{array}$ & $\begin{array}{l}\begin{array}{l}\text { Dept } \\
\text { (cm) }\end{array} \\
54.5\end{array}$ & 54.6 & 54.7 & 54.8 & 54.9 & 55 & 55.1 & 55.2 & 55.3 & 55.4 \\
\hline Unidentified taxa 19 & 0 & 0 & 0 & 0 & 0 & 0 & 0 & 0 & 0 & 0 \\
\hline Unidentified taxa 2 & 3 & 1 & 0 & 2 & 0 & 0 & 3 & 0 & 1 & 0 \\
\hline Unidentified taxa 20 & 0 & 0 & 0 & 0 & 0 & 0 & 0 & 0 & 0 & 0 \\
\hline Unidentified taxa 21 & 0 & 0 & 0 & 0 & 0 & 0 & 0 & 0 & 0 & 0 \\
\hline Unidentified taxa 3 & 4 & 6 & 1 & 0 & 0 & 9 & 0 & 1 & 1 & 2 \\
\hline Unidentified taxa 4 & 0 & 0 & 1 & 0 & 0 & 1 & 0 & 0 & 0 & 2 \\
\hline Unidentified taxa 5 & 0 & 0 & 8 & 2 & 0 & 0 & 0 & 0 & 0 & 0 \\
\hline Unidentified taxa 6 & 0 & 1 & 0 & 2 & 0 & 0 & 0 & 0 & 0 & 0 \\
\hline Unidentified taxa 7 & 1 & 0 & 0 & 1 & 4 & 0 & 0 & 1 & 0 & 0 \\
\hline Unidentified taxa 8 & 0 & 0 & 0 & 0 & 0 & 0 & 0 & 0 & 1 & 0 \\
\hline Unidentified taxa 9 & 0 & 0 & 0 & 0 & 0 & 0 & 0 & 0 & 0 & 0 \\
\hline Navicula schweigeri & 17 & 22 & 0 & 0 & 21 & 18 & 19 & 10 & 20 & 0 \\
\hline Navicula sp10 & 7 & 0 & 2 & 0 & 2 & 0 & 8 & 1 & 3 & 0 \\
\hline Navicula sp11 & 2 & 4 & 6 & 0 & 3 & 7 & 2 & 6 & 0 & 3 \\
\hline Navicula sp12 & 0 & 0 & 0 & 0 & 1 & 1 & 0 & 0 & 0 & 0 \\
\hline Navicula sp13 & 0 & 0 & 0 & 0 & 3 & 0 & 0 & 0 & 0 & 6 \\
\hline Navicula notha & 39 & 46 & 49 & 25 & 37 & 62 & 40 & 40 & 28 & 28 \\
\hline Navicula antonii & 14 & 21 & 21 & 19 & 16 & 8 & 19 & 11 & 13 & 9 \\
\hline Navicula sp4 & 4 & 2 & 3 & 1 & 2 & 3 & 2 & 2 & 11 & 3 \\
\hline Navicula reichardtiana & 7 & 10 & 6 & 22 & 18 & 4 & 12 & 5 & 9 & 3 \\
\hline Nupela impexiformis & 1 & 0 & 1 & 1 & 0 & 1 & 2 & 9 & 2 & 5 \\
\hline Navicula cryptotenella & 48 & 52 & 69 & 46 & 55 & 40 & 54 & 40 & 42 & 39 \\
\hline
\end{tabular}




\begin{tabular}{|c|c|c|c|c|c|c|c|c|c|c|}
\hline $\begin{array}{l}\text { Updated Species Name (Guiry and Guiry, } \\
\text { 2018) }\end{array}$ & $\begin{array}{l}\text { Deptl } \\
\text { (cm) }\end{array}$ & 54.6 & 54.7 & 54.8 & 54.9 & 55 & 55.1 & 55.2 & 55.3 & 55.4 \\
\hline Navicula sp8 & 6 & 10 & 13 & 0 & 6 & 6 & 3 & 9 & 9 & 7 \\
\hline Navicula wildii & 12 & 6 & 1 & 9 & 7 & 9 & 14 & 12 & 10 & 22 \\
\hline Nedium sp1 & 1 & 1 & 5 & 3 & 0 & 2 & 0 & 2 & 3 & 5 \\
\hline Nedium sp2 & 4 & 3 & 7 & 5 & 4 & 9 & 2 & 1 & 3 & 2 \\
\hline Nitzschia palea var. tenuirostris & 112 & 85 & 75 & 84 & 77 & 116 & 94 & 109 & 113 & 132 \\
\hline Nitzschia sp2 & 8 & 0 & 2 & 0 & 2 & 1 & 0 & 2 & 1 & 2 \\
\hline Nitzschia sp3 & 4 & 15 & 5 & 9 & 5 & 8 & 6 & 11 & 5 & 14 \\
\hline Nitzschia amphibia & 1 & 3 & 1 & 0 & 1 & 0 & 0 & 1 & 0 & 1 \\
\hline Pinnularia sp1 & 5 & 3 & 4 & 6 & 7 & 6 & 7 & 3 & 6 & 3 \\
\hline Pinnularia biceps & 5 & 13 & 12 & 5 & 7 & 6 & 8 & 9 & 6 & 5 \\
\hline Psamnothidium sp1 & 2 & 2 & 1 & 5 & 4 & 1 & 1 & 1 & 0 & 0 \\
\hline Pseudostaurosira sp1 & 1 & 0 & 2 & 4 & 0 & 0 & 3 & 4 & 3 & 4 \\
\hline Pseudostaurosira brevistriata & 0 & 3 & 3 & 3 & 0 & 1 & 5 & 4 & 5 & 5 \\
\hline Sellaphora pupula & 20 & 24 & 42 & 31 & 17 & 23 & 20 & 18 & 23 & 17 \\
\hline Sellaphora sp2 & 0 & 0 & 4 & 1 & 2 & 0 & 11 & 1 & 1 & 0 \\
\hline Sellaphora sp3 & 0 & 0 & 0 & 0 & 0 & 0 & 0 & 0 & 0 & 0 \\
\hline Stauroneis sp1 & 1 & 3 & 0 & 3 & 4 & 0 & 0 & 2 & 8 & 5 \\
\hline Stauroneis reichardtii & 7 & 12 & 11 & 7 & 0 & 8 & 0 & 5 & 1 & 4 \\
\hline Stauroneis sp3 & 0 & 0 & 0 & 0 & 0 & 0 & 0 & 0 & 0 & 0 \\
\hline Tabellaria sp1 & 0 & 0 & 0 & 0 & 0 & 0 & 5 & 0 & 0 & 0 \\
\hline Trybonella sp1 & 0 & 0 & 0 & 0 & 0 & 0 & 0 & 0 & 0 & 0 \\
\hline Ulnaria sp1 & 2 & 0 & 0 & 2 & 0 & 0 & 0 & 4 & 0 & 0 \\
\hline
\end{tabular}




\begin{tabular}{|c|c|c|c|c|c|c|c|c|c|c|}
\hline $\begin{array}{l}\text { Updated Species Name (Guiry and Guiry, } \\
\text { 2018) }\end{array}$ & $\begin{array}{l}\begin{array}{l}\text { Depth } \\
\text { (cm) }\end{array} \\
55.5\end{array}$ & 55.6 & 55.7 & 55.8 & 55.9 & 56 & 56.1 & 56.2 & 56.3 & 56.4 \\
\hline Achnanthidium atomus & 22 & 24 & 21 & 39 & 31 & 28 & 36 & 25 & 27 & 34 \\
\hline Achnanthidium sp2 & 0 & 0 & 0 & 0 & 1 & 2 & 0 & 1 & 1 & 0 \\
\hline Achnanthidium minutissimum & 11 & 17 & 10 & 17 & 13 & 12 & 9 & 10 & 10 & 18 \\
\hline Achnanthidium sp4 & 2 & 4 & 1 & 2 & 3 & 5 & 6 & 7 & 1 & 5 \\
\hline Achnanthidium sp5 & 7 & 0 & 3 & 4 & 3 & 3 & 9 & 9 & 4 & 8 \\
\hline Amphora sp1 & 0 & 1 & 1 & 0 & 2 & 0 & 0 & 1 & 0 & 1 \\
\hline Aneumastus sp1 & 0 & 0 & 0 & 0 & 0 & 0 & 1 & 0 & 0 & 0 \\
\hline Brachysira microcephala & 77 & 60 & 78 & 76 & 79 & 71 & 77 & 92 & 111 & 64 \\
\hline Cyclostephanos invisitatus & 6 & 4 & 1 & 4 & 13 & 2 & 0 & 4 & 4 & 4 \\
\hline Lindavia michiganiana & 10 & 21 & 11 & 9 & 7 & 5 & 8 & 11 & 11 & 7 \\
\hline Cyclotella distinguenda & 8 & 9 & 8 & 1 & 12 & 5 & 14 & 9 & 8 & 4 \\
\hline Discostella pseudostelligera & 15 & 18 & 17 & 14 & 16 & 14 & 15 & 19 & 16 & 11 \\
\hline Cyclotella sp5 & 2 & 0 & 0 & 0 & 0 & 0 & 0 & 0 & 0 & 0 \\
\hline Cyclotella sp6 & 0 & 0 & 0 & 0 & 0 & 0 & 2 & 0 & 1 & 0 \\
\hline Cymbopleura sp1 & 2 & 0 & 0 & 1 & 0 & 1 & 1 & 1 & 1 & 3 \\
\hline Denticula elegans & 13 & 5 & 6 & 1 & 4 & 0 & 2 & 3 & 2 & 2 \\
\hline Encyonema sp1 & 6 & 5 & 4 & 3 & 7 & 3 & 4 & 6 & 4 & 4 \\
\hline Encyonopsis falaisensis & 7 & 6 & 8 & 2 & 6 & 7 & 4 & 10 & 7 & 8 \\
\hline Encyonema sp3 & 0 & 1 & 0 & 5 & 1 & 6 & 2 & 3 & 4 & 3 \\
\hline Encyonema sp4 & 0 & 3 & 2 & 2 & 0 & 0 & 0 & 0 & 1 & 1 \\
\hline Encyonema sp5 & 5 & 6 & 7 & 2 & 2 & 1 & 5 & 5 & 2 & 0 \\
\hline Encyonema hebridicum & 6 & 4 & 10 & 7 & 12 & 11 & 6 & 7 & 8 & 18 \\
\hline Encyonema sp7 & 4 & 0 & 4 & 3 & 3 & 5 & 8 & 1 & 5 & 0 \\
\hline Encyonema sp8 & 0 & 0 & 0 & 0 & 0 & 0 & 0 & 0 & 0 & 0 \\
\hline Encyonopsis microcephala & 58 & 68 & 65 & 73 & 51 & 53 & 59 & 54 & 49 & 23 \\
\hline Hantzschia amphioxys & 2 & 5 & 4 & 5 & 3 & 9 & 4 & 1 & 5 & 0 \\
\hline Mayamaea sp1 & 4 & 5 & 3 & 0 & 0 & 0 & 0 & 0 & 0 & 3 \\
\hline Unidentified taxa 11 & 0 & 0 & 0 & 0 & 2 & 1 & 0 & 1 & 0 & 0 \\
\hline Unidentified taxa 12 & 0 & 0 & 0 & 0 & 0 & 0 & 0 & 0 & 0 & 0 \\
\hline Unidentified taxa 13 & 0 & 0 & 0 & 0 & 0 & 0 & 0 & 0 & 0 & 0 \\
\hline Unidentified taxa 14 & 0 & 0 & 0 & 1 & 0 & 3 & 3 & 2 & 4 & 0 \\
\hline Unidentified taxa 15 & 0 & 0 & 0 & 0 & 0 & 0 & 0 & 0 & 0 & 0 \\
\hline Unidentified taxa 16 & 0 & 0 & 0 & 0 & 2 & 0 & 1 & 2 & 0 & 0 \\
\hline Unidentified taxa 17 & 0 & 0 & 0 & 0 & 1 & 0 & 0 & 0 & 0 & 0 \\
\hline Unidentified taxa 18 & 0 & 0 & 0 & 0 & 0 & 0 & 0 & 0 & 0 & 0 \\
\hline
\end{tabular}




\begin{tabular}{|c|c|c|c|c|c|c|c|c|c|c|}
\hline $\begin{array}{l}\text { Updated Species Name (Guiry and Guiry, } \\
\text { 2018) }\end{array}$ & $\begin{array}{l}\begin{array}{l}\text { Dept } \\
\text { (cm) }\end{array} \\
55.5\end{array}$ & 55.6 & 55.7 & 55.8 & 55.9 & 56 & 56.1 & 56.2 & 56.3 & 56.4 \\
\hline Unidentified taxa 19 & 0 & 0 & 0 & 0 & 1 & 0 & 0 & 0 & 0 & 0 \\
\hline Unidentified taxa 2 & 0 & 5 & 5 & 5 & 0 & 0 & 0 & 0 & 0 & 0 \\
\hline Unidentified taxa 20 & 0 & 0 & 0 & 0 & 0 & 0 & 0 & 0 & 0 & 0 \\
\hline Unidentified taxa 21 & 0 & 0 & 0 & 0 & 0 & 0 & 0 & 0 & 0 & 0 \\
\hline Unidentified taxa 3 & 0 & 0 & 1 & 1 & 0 & 0 & 4 & 1 & 2 & 1 \\
\hline Unidentified taxa 4 & 0 & 0 & 0 & 0 & 0 & 0 & 0 & 0 & 0 & 0 \\
\hline Unidentified taxa 5 & 1 & 0 & 0 & 0 & 0 & 2 & 0 & 0 & 0 & 0 \\
\hline Unidentified taxa 6 & 0 & 0 & 4 & 0 & 3 & 3 & 1 & 0 & 0 & 0 \\
\hline Unidentified taxa 7 & 0 & 0 & 0 & 0 & 4 & 0 & 0 & 0 & 0 & 0 \\
\hline Unidentified taxa 8 & 0 & 0 & 0 & 0 & 0 & 1 & 0 & 0 & 0 & 1 \\
\hline Unidentified taxa 9 & 0 & 0 & 1 & 0 & 0 & 0 & 0 & 14 & 0 & 0 \\
\hline Navicula schweigeri & 10 & 4 & 9 & 21 & 11 & 14 & 21 & 3 & 21 & 22 \\
\hline Navicula sp10 & 0 & 0 & 0 & 0 & 5 & 2 & 5 & 5 & 3 & 1 \\
\hline Navicula sp11 & 3 & 5 & 7 & 1 & 7 & 7 & 3 & 3 & 4 & 4 \\
\hline Navicula sp12 & 1 & 1 & 0 & 2 & 0 & 0 & 0 & 0 & 0 & 0 \\
\hline Navicula sp13 & 0 & 0 & 0 & 0 & 0 & 2 & 2 & 0 & 4 & 3 \\
\hline Navicula notha & 33 & 20 & 25 & 26 & 36 & 27 & 33 & 26 & 20 & 54 \\
\hline Navicula antonii & 9 & 38 & 16 & 17 & 7 & 12 & 8 & 11 & 7 & 6 \\
\hline Navicula sp4 & 5 & 6 & 7 & 2 & 6 & 5 & 7 & 5 & 6 & 6 \\
\hline Navicula reichardtiana & 18 & 11 & 25 & 2 & 7 & 13 & 7 & 9 & 10 & 4 \\
\hline Nupela impexiformis & 0 & 4 & 0 & 3 & 1 & 1 & 0 & 0 & 1 & 0 \\
\hline Navicula cryptotenella & 41 & 38 & 20 & 21 & 49 & 35 & 44 & 37 & 45 & 56 \\
\hline
\end{tabular}




\begin{tabular}{|c|c|c|c|c|c|c|c|c|c|c|}
\hline $\begin{array}{l}\text { Updated Species Name (Guiry and Guiry, } \\
\text { 2018) }\end{array}$ & $\begin{array}{l}\begin{array}{l}\text { Depth } \\
\text { (cm) }\end{array} \\
55.5\end{array}$ & 55.6 & 55.7 & 55.8 & 55.9 & 56 & 56.1 & 56.2 & 56.3 & 56.4 \\
\hline Navicula sp8 & 19 & 3 & 14 & 1 & 20 & 11 & 6 & 13 & 14 & 9 \\
\hline Navicula wildii & 18 & 10 & 13 & 7 & 9 & 7 & 10 & 8 & 4 & 5 \\
\hline Nedium sp1 & 2 & 3 & 6 & 0 & 0 & 0 & 0 & 0 & 1 & 5 \\
\hline Nedium sp2 & 2 & 1 & 2 & 4 & 3 & 5 & 8 & 0 & 4 & 12 \\
\hline Nitzschia palea var. tenuirostris & 119 & 135 & 130 & 150 & 115 & 154 & 136 & 141 & 124 & 123 \\
\hline Nitzschia sp2 & 2 & 7 & 4 & 0 & 7 & 7 & 5 & 3 & 2 & 1 \\
\hline Nitzschia sp3 & 2 & 0 & 22 & 4 & 4 & 13 & 11 & 10 & 11 & 5 \\
\hline Nitzschia amphibia & 0 & 15 & 1 & 3 & 2 & 0 & 0 & 1 & 0 & 1 \\
\hline Pinnularia sp1 & 1 & 1 & 4 & 8 & 3 & 4 & 3 & 3 & 1 & 6 \\
\hline Pinnularia biceps & 6 & 3 & 7 & 8 & 3 & 4 & 3 & 8 & 10 & 15 \\
\hline Psamnothidium sp1 & 5 & 1 & 0 & 2 & 7 & 0 & 0 & 1 & 0 & 1 \\
\hline Pseudostaurosira sp1 & 9 & 0 & 4 & 4 & 3 & 1 & 3 & 3 & 2 & 1 \\
\hline Pseudostaurosira brevistriata & 4 & 5 & 2 & 4 & 3 & 1 & 0 & 0 & 3 & 5 \\
\hline Sellaphora pupula & 17 & 15 & 11 & 21 & 13 & 16 & 20 & 15 & 17 & 41 \\
\hline Sellaphora sp2 & 0 & 4 & 0 & 0 & 0 & 0 & 0 & 0 & 1 & 0 \\
\hline Sellaphora sp3 & 0 & 0 & 0 & 0 & 0 & 2 & 0 & 0 & 0 & 0 \\
\hline Stauroneis sp1 & 0 & 0 & 3 & 4 & 3 & 1 & 1 & 4 & 4 & 3 \\
\hline Stauroneis reichardtii & 6 & 0 & 9 & 5 & 9 & 10 & 1 & 4 & 9 & 12 \\
\hline Stauroneis sp3 & 0 & 0 & 0 & 0 & 0 & 0 & 2 & 0 & 0 & 0 \\
\hline Tabellaria sp1 & 7 & 0 & 0 & 1 & 0 & 1 & 0 & 0 & 0 & 0 \\
\hline Trybonella sp1 & 0 & 0 & 0 & 0 & 0 & 0 & 0 & 0 & 1 & 0 \\
\hline Ulnaria sp1 & 1 & 6 & 4 & 3 & 1 & 0 & 0 & 0 & 0 & 0 \\
\hline
\end{tabular}




\section{Appendix C: Selected Geochemical Data, End-Member Proportions, Sedimentation Rate and TSI Values for PKT_2FR2}

Presented here are the concentrations of selected elements, end-member proportions, calculated sedimentation rate, and calculated TSI values based on Steinhilber et al., (2009). The chosen environmental parameters are those that were either included in the final RDA model or discussed in chapter 2 . The approximate date corresponding to each sample derived from the age-depth model is noted below the sample depth. Rock Eval data was obtained from PKT_1FR due to insufficient material provided in the PKT_2FR samples. Values were aligned based on the depth of the White River Ash Eastern Lobe tephra layer observed in both cores $(\sim 35 \mathrm{~cm}$ in PKT_1FR and 55.7-55.4 cm in PKT_2FR). Small sample size resulted in the S1, S3, Residual Carbon, and therefore TOC being unreliable. S2 provided the most reliable data, however, even its accuracy is questionable. 


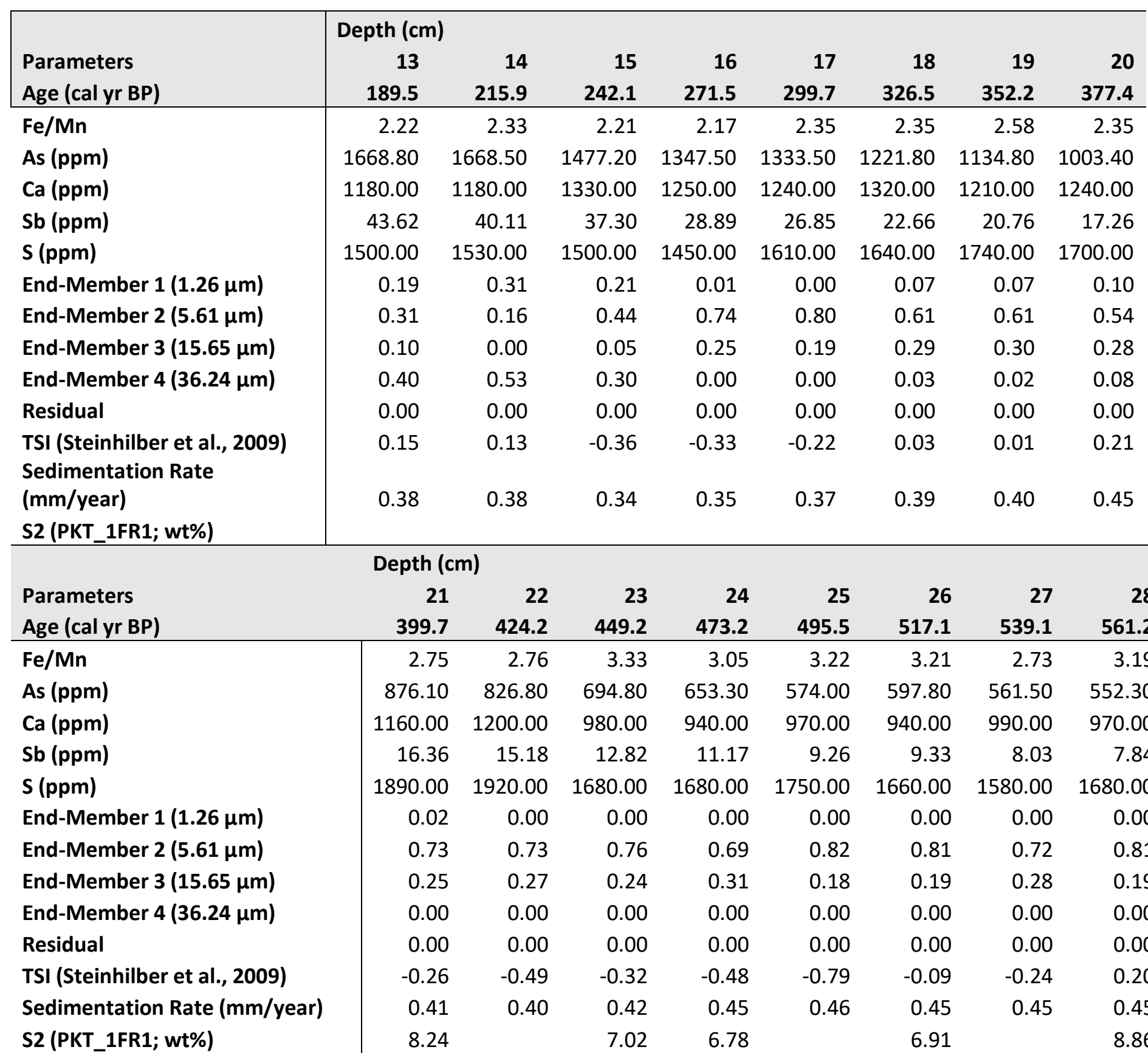




\begin{tabular}{|c|c|c|c|c|c|c|c|}
\hline Parameters & $\begin{array}{c}\text { Depth (cm } \\
29\end{array}$ & 30 & 31 & 32 & 33 & 34 & 35 \\
\hline Age (cal yr BP) & 583.2 & 603.8 & 624.4 & 646.2 & 667.6 & 688.4 & 709.1 \\
\hline $\mathrm{Fe} / \mathrm{Mn}$ & 3.48 & 3.48 & 3.32 & 2.81 & 2.96 & 3.03 & 3.25 \\
\hline As (ppm) & 503.30 & 535.80 & 552.90 & 524.80 & 524.40 & 484.80 & 458.40 \\
\hline $\mathrm{Ca}(\mathrm{ppm})$ & 840.00 & 980.00 & 1010.00 & 1010.00 & 1050.00 & 990.00 & 990.00 \\
\hline $\mathrm{Sb}$ (ppm) & 6.88 & 7.38 & 8.11 & 7.30 & 6.85 & 6.01 & 5.48 \\
\hline$S$ (ppm) & 1710.00 & 2050.00 & 1880.00 & 1630.00 & 1710.00 & 1640.00 & 1870.00 \\
\hline End-Member $1(1.26 \mu \mathrm{m})$ & 0.08 & 0.00 & 0.01 & 0.01 & 0.01 & 0.35 & 0.34 \\
\hline End-Member $2(5.61 \mu \mathrm{m})$ & 0.77 & 0.82 & 0.78 & 0.77 & 0.58 & 0.28 & 0.50 \\
\hline End-Member $3(15.65 \mu \mathrm{m})$ & 0.14 & 0.17 & 0.21 & 0.21 & 0.34 & 0.00 & 0.00 \\
\hline End-Member 4 (36.24 $\mu \mathrm{m})$ & 0.00 & 0.01 & 0.01 & 0.01 & 0.06 & 0.37 & 0.16 \\
\hline Residual & 0.00 & 0.00 & 0.00 & 0.00 & 0.01 & 0.00 & 0.00 \\
\hline TSI (Steinhilber et al., 2009) & 0.48 & 0.26 & -0.26 & -0.42 & -0.53 & 0.07 & 0.49 \\
\hline $\begin{array}{l}\text { Sedimentation Rate } \\
\text { (mm/year) }\end{array}$ & 0.49 & 0.49 & 0.46 & 0.47 & 0.48 & 0.48 & 0.49 \\
\hline S2 (PKT_1FR1; wt\%) & 6.27 & & 10.43 & 8.88 & 7.83 & 10.16 & 8.92 \\
\hline Parameters & $\begin{array}{c}\text { Depth (cm } \\
36\end{array}$ & 37 & 38 & 39 & 40 & 41 & 42 \\
\hline Age (cal yr BP) & 729.6 & 751.3 & 772.8 & 794.1 & 814.3 & 834.6 & 855.5 \\
\hline $\mathrm{Fe} / \mathrm{Mn}$ & 3.42 & 3.28 & 3.11 & 3.07 & 2.97 & 3.07 & 3.32 \\
\hline As (ppm) & 422.90 & 396.80 & 377.70 & 360.20 & 375.50 & 359.90 & 331.00 \\
\hline $\mathrm{Ca}$ (ppm) & 920.00 & 910.00 & 910.00 & 940.00 & 950.00 & 1030.00 & 860.00 \\
\hline Sb (ppm) & 5.13 & 4.62 & 5.08 & 143.42 & 4.69 & 4.79 & 4.00 \\
\hline$S$ (ppm) & 1850.00 & 1720.00 & 1720.00 & 1750.00 & 1760.00 & 1990.00 & 1820.00 \\
\hline End-Member $1(1.26 \mu \mathrm{m})$ & 0.02 & 0.01 & 0.03 & 0.02 & 0.02 & 0.00 & 0.03 \\
\hline End-Member $2(5.61 \mu \mathrm{m})$ & 0.96 & 0.98 & 0.96 & 0.97 & 0.80 & 0.33 & 0.35 \\
\hline End-Member $3(15.65 \mu \mathrm{m})$ & 0.02 & 0.00 & 0.00 & 0.00 & 0.19 & 0.33 & 0.40 \\
\hline End-Member 4 (36.24 $\mu \mathrm{m})$ & 0.01 & 0.01 & 0.01 & 0.01 & 0.00 & 0.33 & 0.22 \\
\hline Residual & 0.00 & 0.00 & 0.00 & 0.00 & 0.00 & 0.00 & 0.00 \\
\hline TSI (Steinhilber et al., 2009) & 0.11 & 0.26 & 0.09 & 0.17 & 0.30 & 0.07 & 0.27 \\
\hline $\begin{array}{l}\text { Sedimentation Rate } \\
\text { (mm/year) }\end{array}$ & 0.46 & 0.47 & 0.47 & 0.50 & 0.49 & 0.48 & 0.46 \\
\hline S2 (PKT_1FR1; wt\%) & 11.81 & 8.91 & 9.53 & 7.24 & 7.35 & 8.31 & \\
\hline
\end{tabular}




\begin{tabular}{|c|c|c|c|c|c|c|c|c|}
\hline Parameters & $\begin{array}{r}\text { Depth (cr } \\
43\end{array}$ & 44 & 45 & 46 & 47 & 48 & 49 & 50 \\
\hline Age (cal yr BP) & 877.3 & 897.8 & 918.1 & 937.6 & 957.1 & 977.8 & 998.6 & 1018.5 \\
\hline $\mathrm{Fe} / \mathrm{Mn}$ & 3.30 & 3.73 & 3.29 & 2.86 & 3.04 & 2.79 & 3.00 & 2.82 \\
\hline As (ppm) & 320.50 & 311.00 & 297.00 & 285.20 & 266.10 & 247.20 & 232.90 & 229.40 \\
\hline $\mathrm{Ca}(\mathrm{ppm})$ & 930.00 & 850.00 & 910.00 & 920.00 & 900.00 & 870.00 & 860.00 & 900.00 \\
\hline $\mathrm{Sb}$ (ppm) & 4.23 & 4.39 & 3.97 & 4.14 & 3.71 & 3.47 & 3.57 & 3.30 \\
\hline$S(p p m)$ & 1960.00 & 1980.00 & 1910.00 & 1700.00 & 1530.00 & 1480.00 & 1490.00 & 1440.00 \\
\hline End-Member $1(1.26 \mu \mathrm{m})$ & 0.04 & 0.03 & 0.06 & 0.06 & 0.07 & 0.03 & 0.00 & 0.19 \\
\hline End-Member $2(5.61 \mu \mathrm{m})$ & 0.40 & 0.40 & 0.36 & 0.22 & 0.46 & 0.44 & 0.66 & 0.06 \\
\hline End-Member $3(15.65 \mu \mathrm{m})$ & 0.35 & 0.33 & 0.01 & 0.01 & 0.02 & 0.26 & 0.06 & 0.00 \\
\hline End-Member 4 (36.24 $\mu \mathrm{m})$ & 0.22 & 0.24 & 0.57 & 0.71 & 0.44 & 0.25 & 0.24 & 0.74 \\
\hline Residual & 0.00 & 0.00 & 0.00 & 0.00 & 0.00 & 0.02 & 0.04 & 0.00 \\
\hline $\begin{array}{l}\text { TSI (Steinhilber et al., 2009) } \\
\text { Sedimentation Rate }\end{array}$ & 0.11 & 0.07 & -0.30 & -0.04 & -0.12 & 0.19 & 0.38 & 0.38 \\
\hline (mm/year) & 0.49 & 0.49 & 0.51 & 0.51 & 0.48 & 0.48 & 0.50 & 0.56 \\
\hline \multirow[t]{2}{*}{ S2 (PKT_1FR1; wt\%) } & & 6.79 & & & 10.32 & & & \multirow[t]{17}{*}{9.27} \\
\hline & Depth (cr & & & & & & & \\
\hline Parameters & 51 & 52 & 53 & 54 & 55 & 56 & 57 & \\
\hline Age (cal yr BP) & 1036.2 & 1054 & 1072.6 & 1092.6 & 1113.1 & 1132 & 1153 & \\
\hline $\mathrm{Fe} / \mathrm{Mn}$ & 2.82 & 3.08 & 2.72 & 2.84 & 2.73 & 3.30 & 3.02 & \\
\hline As (ppm) & 211.20 & 166.20 & 175.90 & 170.90 & 107.70 & 108.30 & 92.10 & \\
\hline $\mathrm{Ca}$ (ppm) & 970.00 & 790.00 & 890.00 & 830.00 & 680.00 & 660.00 & 740.00 & \\
\hline Sb (ppm) & 3.29 & 2.97 & 3.14 & 3.03 & 2.36 & 3.07 & 3.13 & \\
\hline$S$ (ppm) & 1510.00 & 1440.00 & 1590.00 & 1520.00 & 1080.00 & 1460.00 & 1560.00 & \\
\hline End-Member $1(1.26 \mu \mathrm{m})$ & 0.00 & 0.21 & 0.07 & 0.00 & 0.00 & 0.00 & 0.00 & \\
\hline End-Member $2(5.61 \mu \mathrm{m})$ & 0.53 & 0.13 & 0.57 & 0.73 & 0.00 & 0.00 & 0.48 & \\
\hline End-Member 3 (15.65 $\mu \mathrm{m})$ & 0.08 & 0.00 & 0.14 & 0.27 & 0.00 & 0.00 & 0.52 & \\
\hline End-Member 4 (36.24 $\mu \mathrm{m})$ & 0.39 & 0.64 & 0.21 & 0.00 & 0.00 & 0.00 & 0.00 & \\
\hline Residual & 0.00 & 0.02 & 0.00 & 0.00 & 0.00 & 0.00 & 0.00 & \\
\hline TSI (Steinhilber et al., 2009) & -0.03 & -0.26 & 0.25 & 0.26 & 0.11 & 0.27 & 0.37 & \\
\hline $\begin{array}{l}\text { Sedimentation Rate } \\
\text { (mm/year) }\end{array}$ & 0.56 & 0.54 & 0.50 & 0.49 & 0.53 & 0.48 & 0.53 & \\
\hline S2 (PKT_1FR1; wt\%) & 9.56 & 7.89 & & & & 8.84 & 8.27 & \\
\hline
\end{tabular}




\begin{tabular}{|c|c|c|c|c|c|c|c|}
\hline Parameters & $\begin{array}{r}\text { Depth (cr } \\
58\end{array}$ & 59 & 60 & 61 & 62 & 63 & 64 \\
\hline Age (cal yr BP) & 1171.8 & 1190.2 & 1208.8 & 1233.3 & 1257.1 & 1279.3 & 1301.5 \\
\hline $\mathrm{Fe} / \mathrm{Mn}$ & 3.55 & 3.28 & 2.80 & 2.73 & 2.83 & 2.82 & 2.45 \\
\hline As (ppm) & 95.80 & 96.90 & 73.90 & 58.50 & 52.20 & 52.10 & 44.60 \\
\hline $\mathrm{Ca}$ (ppm) & 800.00 & 810.00 & 1010.00 & 1010.00 & 1020.00 & 1000.00 & 1020.00 \\
\hline $\mathrm{Sb}$ (ppm) & 3.84 & 4.06 & 4.06 & 4.15 & 3.91 & 4.01 & 4.03 \\
\hline$S$ (ppm) & 2080.00 & 1740.00 & 1830.00 & 1690.00 & 1670.00 & 1660.00 & 1510.00 \\
\hline End-Member $1(1.26 \mu \mathrm{m})$ & 0.00 & 0.02 & 0.00 & 0.02 & 0.00 & 0.03 & 0.00 \\
\hline End-Member $2(5.61 \mu \mathrm{m})$ & 0.69 & 0.75 & 0.50 & 0.73 & 0.68 & 0.68 & 0.66 \\
\hline End-Member $3(15.65 \mu \mathrm{m})$ & 0.31 & 0.23 & 0.50 & 0.25 & 0.32 & 0.29 & 0.31 \\
\hline End-Member 4 (36.24 $\mu \mathrm{m})$ & 0.00 & 0.00 & 0.00 & 0.00 & 0.00 & 0.00 & 0.02 \\
\hline Residual & 0.00 & 0.00 & 0.00 & 0.00 & 0.00 & 0.00 & 0.00 \\
\hline TSI (Steinhilber et al., 2009) & -0.01 & 0.03 & 0.22 & -0.16 & -0.38 & -0.97 & -0.64 \\
\hline $\begin{array}{l}\text { Sedimentation Rate } \\
\text { (mm/year) }\end{array}$ & 0.54 & 0.54 & 0.41 & 0.42 & 0.45 & 0.45 & 0.48 \\
\hline S2 (PKT_1FR1; wt\%) & 7.78 & 9.04 & 9.79 & 10.45 & 9.90 & 9.52 & 9.73 \\
\hline Parameters & $\begin{array}{c}\text { Depth (cr } \\
65\end{array}$ & 66 & 67 & 68 & 69 & 70 & 71 \\
\hline Age (cal yr BP) & 1322.4 & 1346.9 & 1371.4 & 1395.6 & 1418 & 1439.9 & 1467.7 \\
\hline $\mathrm{Fe} / \mathrm{Mn}$ & 2.54 & 2.66 & 2.80 & 2.95 & 2.92 & 2.93 & 2.88 \\
\hline As (ppm) & 49.00 & 58.30 & 52.20 & 47.90 & 48.70 & 46.40 & 48.30 \\
\hline $\mathrm{Ca}$ (ppm) & 1070.00 & 1040.00 & 910.00 & 960.00 & 940.00 & 1010.00 & 990.00 \\
\hline Sb (ppm) & 4.05 & 3.73 & 3.54 & 3.05 & 3.23 & 3.12 & 2.53 \\
\hline$S$ (ppm) & 1680.00 & 1650.00 & 1440.00 & 1580.00 & 1570.00 & 1590.00 & 1500.00 \\
\hline End-Member $1(1.26 \mu \mathrm{m})$ & 0.00 & 0.01 & 0.04 & 0.00 & 0.00 & 0.00 & 0.02 \\
\hline End-Member $2(5.61 \mu \mathrm{m})$ & 0.58 & 0.67 & 0.64 & 0.57 & 0.58 & 0.22 & 0.79 \\
\hline End-Member $3(15.65 \mu \mathrm{m})$ & 0.42 & 0.32 & 0.32 & 0.43 & 0.42 & 0.78 & 0.18 \\
\hline End-Member 4 (36.24 $\mu \mathrm{m})$ & 0.00 & 0.00 & 0.01 & 0.00 & 0.00 & 0.00 & 0.00 \\
\hline Residual & 0.00 & 0.00 & 0.00 & 0.00 & 0.00 & 0.00 & 0.00 \\
\hline TSI (Steinhilber et al., 2009) & -0.14 & -0.22 & -0.03 & 0.13 & 0.13 & 0.38 & 0.12 \\
\hline $\begin{array}{l}\text { Sedimentation Rate } \\
\text { (mm/year) }\end{array}$ & 0.41 & 0.41 & 0.41 & 0.45 & 0.46 & 0.36 & 0.36 \\
\hline S2 (PKT_1FR1; wt\%) & & 10.48 & 10.98 & 10.36 & 10.00 & 10.48 & 10.31 \\
\hline
\end{tabular}




\begin{tabular}{|c|c|c|c|c|c|c|c|}
\hline Parameters & $\begin{array}{r}\text { Depth (cr } \\
72\end{array}$ & 73 & 74 & 75 & 76 & 77 & 78 \\
\hline Age (cal yr BP) & 1495.4 & 1522.1 & 1548.1 & 1573.3 & 1600.4 & 1628.3 & 1656.1 \\
\hline $\mathrm{Fe} / \mathrm{Mn}$ & 2.86 & 2.70 & 2.80 & 2.61 & 2.56 & 2.55 & 2.58 \\
\hline As (ppm) & 45.50 & 46.00 & 44.10 & 42.20 & 47.70 & 39.60 & 40.90 \\
\hline $\mathrm{Ca}(p p m)$ & 970.00 & 1060.00 & 1030.00 & 980.00 & 920.00 & 950.00 & 960.00 \\
\hline $\mathrm{Sb}$ (ppm) & 2.20 & 2.18 & 1.93 & 1.72 & 1.67 & 1.62 & 1.55 \\
\hline$S$ (ppm) & 1350.00 & 1440.00 & 1430.00 & 1370.00 & 1370.00 & 1360.00 & 1420.00 \\
\hline End-Member $1(1.26 \mu \mathrm{m})$ & 0.00 & 0.00 & 0.00 & 0.00 & 0.00 & 0.00 & 0.00 \\
\hline End-Member $2(5.61 \mu \mathrm{m})$ & 0.63 & 0.60 & 0.59 & 0.43 & 0.41 & 0.31 & 0.37 \\
\hline End-Member $3(15.65 \mu \mathrm{m})$ & 0.37 & 0.40 & 0.41 & 0.56 & 0.59 & 0.68 & 0.62 \\
\hline End-Member 4 (36.24 $\mu \mathrm{m})$ & 0.00 & 0.00 & 0.00 & 0.01 & 0.00 & 0.00 & 0.00 \\
\hline Residual & 0.00 & 0.00 & 0.00 & 0.00 & 0.00 & 0.00 & 0.00 \\
\hline TSI (Steinhilber et al., 2009) & 0.02 & 0.05 & -0.15 & 0.17 & 0.33 & 0.38 & 0.77 \\
\hline $\begin{array}{l}\text { Sedimentation Rate } \\
\text { (mm/year) }\end{array}$ & 0.37 & 0.38 & 0.40 & 0.37 & 0.36 & 0.36 & 0.35 \\
\hline S2 (PKT_1FR1; wt\%) & 10.19 & 10.60 & 10.83 & 10.16 & 9.82 & 10.74 & 11.22 \\
\hline & Depth (cr & & & & & & \\
\hline Parameters & 79 & 80 & 81 & 82 & 83 & 84 & 85 \\
\hline Age (cal yr BP) & 1684.3 & 1711.2 & 1740.4 & 1770 & 1798.9 & 1827.7 & 1855.7 \\
\hline $\mathrm{Fe} / \mathrm{Mn}$ & 2.69 & 2.69 & 2.46 & 2.53 & 2.41 & 2.56 & 2.64 \\
\hline As (ppm) & 41.00 & 40.90 & 46.40 & 54.90 & 48.10 & 38.80 & 34.50 \\
\hline $\mathrm{Ca}(\mathrm{ppm})$ & 970.00 & 900.00 & 1000.00 & 990.00 & 1030.00 & 990.00 & 970.00 \\
\hline $\mathrm{Sb}(p p m)$ & 1.54 & 1.44 & 1.52 & 1.53 & 1.59 & 1.40 & 1.26 \\
\hline$S$ (ppm) & 1430.00 & 1310.00 & 1420.00 & 1410.00 & 1440.00 & 1410.00 & 1410.00 \\
\hline End-Member $1(1.26 \mu \mathrm{m})$ & 0.01 & 0.01 & 0.01 & 0.01 & 0.00 & 0.00 & 0.00 \\
\hline End-Member $2(5.61 \mu \mathrm{m})$ & 0.60 & 0.66 & 0.63 & 0.72 & 0.72 & 0.65 & 0.66 \\
\hline End-Member $3(15.65 \mu \mathrm{m})$ & 0.34 & 0.33 & 0.36 & 0.27 & 0.28 & 0.35 & 0.33 \\
\hline End-Member 4 (36.24 $\mu \mathrm{m})$ & 0.05 & 0.00 & 0.00 & 0.00 & 0.00 & 0.00 & 0.01 \\
\hline Residual & 0.00 & 0.00 & 0.00 & 0.00 & 0.00 & 0.00 & 0.00 \\
\hline TSI (Steinhilber et al., 2009) & 0.21 & -0.11 & 0.49 & 0.17 & 0.39 & 0.23 & -0.42 \\
\hline $\begin{array}{l}\text { Sedimentation Rate } \\
\text { (mm/year) }\end{array}$ & 0.37 & 0.34 & 0.34 & 0.35 & 0.35 & 0.36 & 0.36 \\
\hline S2 (PKT_1FR1; wt\%) & 10.23 & 10.53 & 11.07 & 10.21 & 10.64 & 10.52 & 9.40 \\
\hline
\end{tabular}




\begin{tabular}{|c|c|c|c|c|c|c|c|c|}
\hline Parameters & $\begin{array}{c}\text { Depth (cr } \\
86\end{array}$ & 87 & 88 & 89 & 90 & 91 & 92 & 93 \\
\hline Age (cal yr BP) & 1883.1 & 1911.5 & 1941.3 & 1968.9 & 1995.5 & 2019.6 & 2042.8 & 2067.1 \\
\hline $\mathrm{Fe} / \mathrm{Mn}$ & 2.62 & 2.53 & 2.29 & 2.36 & 2.50 & 2.50 & 2.42 & 2.53 \\
\hline As (ppm) & 31.70 & 35.50 & 29.40 & 29.70 & 30.40 & 36.60 & 27.40 & 30.40 \\
\hline $\mathrm{Ca}$ (ppm) & 1010.00 & 970.00 & 1000.00 & 990.00 & 930.00 & 1000.00 & 890.00 & 920.00 \\
\hline $\mathrm{Sb}(\mathrm{ppm})$ & 1.19 & 1.42 & 1.20 & 1.17 & 1.16 & 1.39 & 1.11 & 1.30 \\
\hline$S(p p m)$ & 1280.00 & 1260.00 & 1280.00 & 1330.00 & 1310.00 & 1410.00 & 1340.00 & 1410.00 \\
\hline End-Member $1(1.26 \mu \mathrm{m})$ & 0.02 & 0.01 & 0.03 & 0.02 & 0.06 & 0.04 & 0.02 & 0.06 \\
\hline End-Member $2(5.61 \mu \mathrm{m})$ & 0.64 & 0.71 & 0.82 & 0.73 & 0.72 & 0.48 & 0.47 & 0.60 \\
\hline End-Member $3(15.65 \mu \mathrm{m})$ & 0.24 & 0.23 & 0.09 & 0.23 & 0.18 & 0.45 & 0.50 & 0.24 \\
\hline End-Member 4 (36.24 $\mu \mathrm{m})$ & 0.10 & 0.04 & 0.06 & 0.02 & 0.04 & 0.03 & 0.01 & 0.11 \\
\hline Residual & 0.00 & 0.00 & 0.00 & 0.00 & 0.00 & 0.00 & 0.00 & 0.00 \\
\hline TSI (Steinhilber et al., 2009) & 0.29 & -0.13 & 0.48 & 0.14 & 0.37 & 0.06 & 0.30 & 0.06 \\
\hline $\begin{array}{l}\text { Sedimentation Rate } \\
\text { ( } \mathrm{mm} / \text { year) }\end{array}$ & 0.35 & 0.34 & 0.36 & 0.38 & 0.41 & 0.43 & 0.41 & 0.41 \\
\hline S2 (PKT_1FR1; wt\%) & 11.20 & 11.76 & 11.02 & 10.79 & 11.21 & 10.91 & 10.86 & 9.49 \\
\hline & \multicolumn{3}{|c|}{ Depth $(\mathrm{cm})$} & & & & & \\
\hline Parameters & 94 & 95 & 96 & 97 & 98 & 99 & 100 & \\
\hline Age (cal yr BP) & 2091.7 & 2114.2 & 2133.2 & 2152 & 2169.6 & 2187.6 & 2205.1 & \\
\hline $\mathrm{Fe} / \mathrm{Mn}$ & 2.42 & 2.65 & 2.90 & 2.73 & 2.73 & 2.88 & 2.73 & \\
\hline As (ppm) & 34.20 & 35.30 & 42.60 & 42.40 & 39.10 & 38.50 & 45.90 & \\
\hline $\mathrm{Ca}$ (ppm) & 930.00 & 970.00 & 970.00 & 1050.00 & 1040.00 & 1010.00 & 1010.00 & \\
\hline Sb (ppm) & 1.28 & 1.38 & 1.79 & 1.61 & 1.47 & 1.57 & 1.63 & \\
\hline$S(p p m)$ & 1350.00 & 1440.00 & 1540.00 & 1630.00 & 1500.00 & 1570.00 & 1550.00 & \\
\hline End-Member $1(1.26 \mu \mathrm{m})$ & 0.12 & 0.01 & 0.00 & 0.01 & 0.00 & 0.00 & 0.00 & \\
\hline End-Member $2(5.61 \mu \mathrm{m})$ & 0.24 & 0.32 & 0.06 & 0.05 & 0.21 & 0.09 & 0.66 & \\
\hline End-Member $3(15.65 \mu \mathrm{m})$ & 0.12 & 0.63 & 0.59 & 0.64 & 0.62 & 0.72 & 0.16 & \\
\hline End-Member 4 (36.24 $\mu \mathrm{m})$ & 0.50 & 0.04 & 0.35 & 0.30 & 0.16 & 0.19 & 0.16 & \\
\hline Residual & 0.03 & 0.00 & 0.00 & 0.00 & 0.02 & 0.00 & 0.02 & \\
\hline TSI (Steinhilber et al., 2009) & 0.27 & 0.11 & 0.18 & 0.21 & 0.55 & 0.48 & 0.06 & \\
\hline $\begin{array}{l}\text { Sedimentation Rate } \\
\text { (mm/year) }\end{array}$ & 0.44 & 0.53 & 0.53 & 0.57 & 0.56 & 0.57 & 0.56 & \\
\hline S2 (PKT_1FR1; wt\%) & & & 10.96 & 11.55 & 10.77 & 9.63 & & \\
\hline
\end{tabular}




\begin{tabular}{|c|c|c|c|c|c|c|c|}
\hline Parameters & $\begin{array}{c}\text { Depth (cm } \\
101\end{array}$ & 102 & 103 & 104 & 105 & 106 & 107 \\
\hline Age (cal yr BP) & 2223 & 2241.2 & 2260.1 & 2277.4 & 2294.8 & 2312.2 & 2330 \\
\hline $\mathrm{Fe} / \mathrm{Mn}$ & 2.59 & 2.39 & 2.47 & 2.45 & 2.64 & 2.43 & 2.58 \\
\hline As (ppm) & 48.90 & 40.60 & 47.20 & 51.90 & 42.50 & 43.90 & 43.50 \\
\hline $\mathrm{Ca}(\mathrm{ppm})$ & 1000.00 & 1050.00 & 1050.00 & 1030.00 & 990.00 & 1030.00 & 1080.00 \\
\hline $\mathrm{Sb}$ (ppm) & 1.79 & 1.68 & 1.82 & 1.84 & 1.47 & 1.71 & 1.58 \\
\hline$S$ (ppm) & 1470.00 & 1380.00 & 1440.00 & 1420.00 & 1350.00 & 1410.00 & 1470.00 \\
\hline End-Member $1(1.26 \mu \mathrm{m})$ & 0.00 & 0.00 & 0.00 & 0.00 & 0.00 & 0.00 & 0.00 \\
\hline End-Member $2(5.61 \mu \mathrm{m})$ & 0.44 & 0.45 & 0.28 & 0.14 & 0.28 & 0.11 & 0.22 \\
\hline End-Member $3(15.65 \mu \mathrm{m})$ & 0.53 & 0.50 & 0.50 & 0.34 & 0.58 & 0.49 & 0.40 \\
\hline End-Member 4 (36.24 $\mu \mathrm{m})$ & 0.00 & 0.00 & 0.23 & 0.52 & 0.14 & 0.40 & 0.38 \\
\hline Residual & 0.03 & 0.05 & 0.00 & 0.00 & 0.00 & 0.00 & 0.00 \\
\hline TSI (Steinhilber et al., 2009) & 0.08 & 0.47 & 0.21 & 0.06 & 0.27 & -0.39 & -0.35 \\
\hline $\begin{array}{l}\text { Sedimentation Rate } \\
\text { (mm/year) }\end{array}$ & 0.55 & 0.53 & 0.58 & 0.57 & 0.57 & 0.56 & 0.54 \\
\hline S2 (PKT_1FR1; wt\%) & & 11.05 & 10.52 & 10.97 & 11.89 & 12.07 & 11.15 \\
\hline Parameters & $\begin{array}{c}\text { Depth (cm } \\
108\end{array}$ & 109 & 110 & 111 & 112 & 113 & 114 \\
\hline Age (cal yr BP) & 2348.4 & 2365.7 & 2384.7 & 2403.4 & 2423.4 & 2442.6 & 2461.6 \\
\hline $\mathrm{Fe} / \mathrm{Mn}$ & 2.55 & 2.47 & 2.53 & 2.38 & 2.44 & 2.35 & 2.28 \\
\hline As (ppm) & 44.00 & 42.00 & 41.30 & 43.50 & 42.70 & 44.40 & 58.70 \\
\hline $\mathrm{Ca}$ (ppm) & 1090.00 & 1010.00 & 1090.00 & 1120.00 & 1060.00 & 1040.00 & 1080.00 \\
\hline Sb (ppm) & 1.66 & 1.85 & 1.68 & 1.64 & 1.73 & 1.67 & 1.78 \\
\hline$S$ (ppm) & 1450.00 & 1400.00 & 1490.00 & 1510.00 & 1400.00 & 1390.00 & 1380.00 \\
\hline End-Member $1(1.26 \mu \mathrm{m})$ & 0.00 & 0.00 & 0.00 & 0.00 & 0.00 & 0.00 & 0.00 \\
\hline End-Member $2(5.61 \mu \mathrm{m})$ & 0.40 & 0.16 & 0.26 & 0.06 & 0.21 & 0.29 & 0.14 \\
\hline End-Member $3(15.65 \mu \mathrm{m})$ & 0.56 & 0.61 & 0.60 & 0.50 & 0.49 & 0.53 & 0.55 \\
\hline End-Member 4 (36.24 $\mu \mathrm{m})$ & 0.04 & 0.23 & 0.14 & 0.43 & 0.28 & 0.18 & 0.30 \\
\hline Residual & 0.00 & 0.00 & 0.01 & 0.00 & 0.02 & 0.00 & 0.00 \\
\hline TSI (Steinhilber et al., 2009) & -0.19 & -0.14 & 0.14 & 0.43 & 0.59 & 0.31 & 0.26 \\
\hline $\begin{array}{l}\text { Sedimentation Rate } \\
\text { (mm/year) }\end{array}$ & 0.58 & 0.53 & 0.53 & 0.50 & 0.52 & 0.53 & 0.44 \\
\hline S2 (PKT_1FR1; wt\%) & 11.64 & 13.24 & & & 10.68 & 11.26 & 12.52 \\
\hline
\end{tabular}




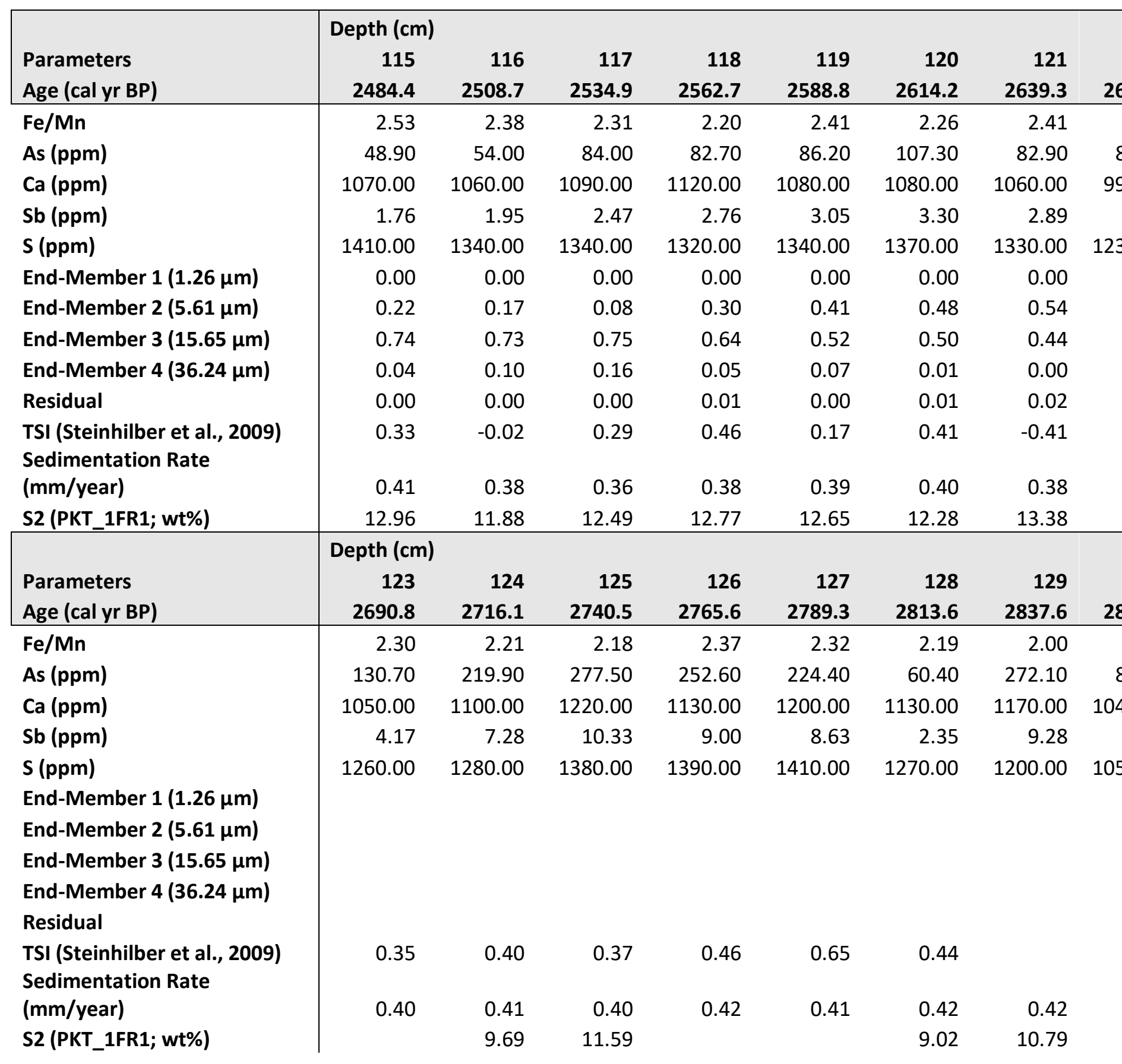


